JHANTIBOOK OF PATENT LAW OF ALL COUNTRIES

W. P. TJUOMPSON 


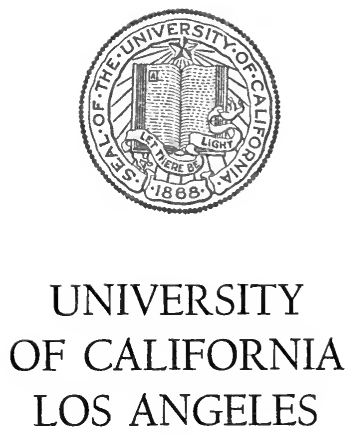

SCHOOL OF LAW

LIBRARY

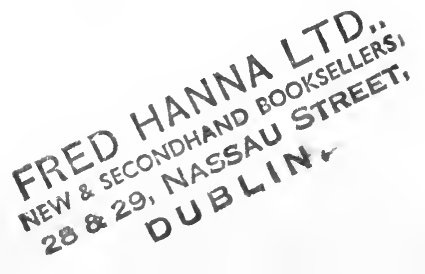




HANDBOOK OF PATENT LAW OF ALL COUNTRIES 


\section{W. P. THOMPSON \& CO.,}

ESTABLISHED 1873.

\section{CHARTERED PATENT AND REGISTERED AGENTS}

\section{FOR PROCURING BRITISH AND FOREIGN PATENTS, REGISTERING DESIGNS AND TRADE MARKS.}

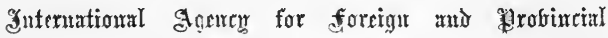
gatent Solicitors. Sole Offices

12, CHURCH STREET, LIVERPOOL.

\section{PRINCIPALS.}

W. P. Thompson, F.C.S.; M.I.Mech.E., F.I.C.P.A.

G. C. Dymond, M.I.Mech.F., F.I.C.P.A.

H. E. Potrs, M.Sc. (Liverpool), Honours in Chemistry, F.I.C.P.A.

J. V. Armstrong, M.T.I., F.I.C.P.A.

W. H. Beeston, R.P.A. 


\title{
HANDBOOK OF PATENT LAW OF ALL COUNTRIES
}

\author{
BY \\ W. P. THOMPSON \\ Fellow of the Chemical Society \\ Member of the Institution of Mechanical Engineers \\ Fellow of the Chartered Institute of Patent Agents \\ Fellow of the Australian Institute of Patent Agents \\ Honorary Patent Agent of the Society of Dyers and Colourists \\ Member of the Patent Law Association, Washington \\ Head of the International Patent Bureaw, Liverpool \\ and Certified United States \\ Patent Attorney
}

EIGHTFENTH EDITION, COMPLETELY REVISED.

\section{LONDON}

STEVENS \& SONS, LIMITED, II9, CHANCERY LANE

1920

COPYRIGHT 
$T$

T3797p

$$
\begin{aligned}
& 323462 \\
& =21.54 \\
& +74
\end{aligned}
$$




\section{PREFACE TO THE EIGHTEENTH EDITION}

THE present edition has been completely revised. It is not written with the object of enabling every man to be his own Patent Agent, for it is simply impossible for any one to become a good Patent Agent without years of training, and without having special adaptability to the work. Its aim is to act as a useful guide to patentees, manufacturers, and investors in patents. It is also written with a view of answering the multitudinous inquiries as to the law of patenting which the author's firm daily receives in the course of its business.

In former editions, the average fees for procuring Patents at home and abroad were inserted. These were only very approximate, as the costs of patents differ widely according to the complexity of the invention, and from other causes. The Council of the Chartered Institute of Patent Agents, under the authority of the Board of Trade, have issued a minimum list of prices of Patents and Trade Marks for all countries which their members are governed by.

The great treaty between the belligerents in the late war contains clauses whereby their citizens can yet patent, in the other countries parties to that treaty, all inventions patented in any of those countries since I August, I9I3, if applied within a given period in each country after the signing of the treaty which took place Io January, I920. Several other countries have given similar advantages, especially Sweden, Norway, Denmark, Spain and Colonial Dominions of Great Britain. 
I am indebted to many of my firm's agents for so kindly revising the parts relating to their respective countries.

That the book may be worthy of the kind favour which the previous editions so amply received, and be a genuine assistance to Patent Agents, Inventors, Manufacturers, and Patent Investors generally, is the earnest wish of the Author.

12, Church Street,

LIVERPOOL. 


\section{TABLE OF CONTENTS}

PREFACE .

BRITISH PATENT LAW

WHO CAN PATENT

JOINT INVENTION .

WHAT CAN BE PATENTED .

WHAT INVENTIONS ARE MOST PROFITABLE.

RIGHTS CONFERRED BY PATENTS

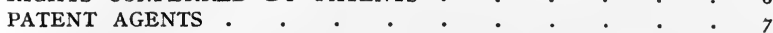

PROCEDURE FOR OBTAINING A BRITISH PATENT . . 8

PROVISIONAL PROTECTION • • • • • • . . . . . 9

FIRST EXAMINATION . . . . . . . . . . . . . II

COMPLETE SPECIFICATION • • • • • . . . . . 12

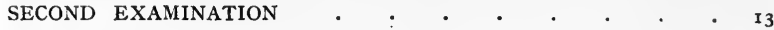

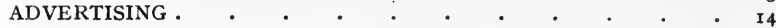

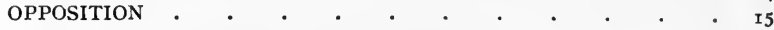

PATENTS OF ADDITION . . . . . . . . . . . . . 17

WORKING AND ABUSE OF MONOPOLY • . . . . . . I7

SUBSEQUENT TAXES : . . . . . . . . . . . . 19

PROLONGATIONS • . . . . . . . . . . 20

DISCLAIMERS AND AMENDMENTS . . . . . . . 20

PRINTED COPIES ..$\quad$. . . . . . . . . ${ }^{22}$

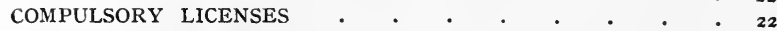

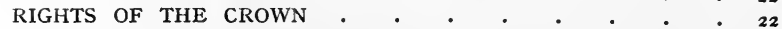

INTERNATIONAL PROTECTION $\quad \cdot \quad \cdot \quad \cdot \quad \cdot \quad \cdot \quad \cdot \quad \cdot \quad 22$

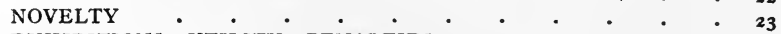

EXHIBITIONS, UTILITY, PENALTIES • • . . . . ${ }_{25}$

SEARCHING . . . . . . . . . . . 26

REVOCATIONS . • • • • • • • • • • • $\quad$ • 27

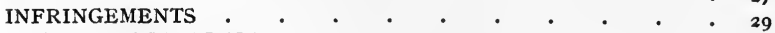

LEGAL PROCEEDINGS • • • • • • • • • • . 30

LICENSES AND ASSIGNMENTS • • . • • . • • 32

HOW TO SELL A PATENT . • . • . • • • • 33

INVESTING IN PATENTS • . • . . . . . . 34

DESIGN REGISTRATION • . • • • . . . . ${ }_{36}$

PATENT MEDICINES . . . . . . . . . . . 40

REGISTRATION OF TRADE MARKS . . . . . . : 40

WHAT CAN BE REGISTERED . . . . . . . . $4 \mathrm{I}$

PART "A" AND PART "B" MARKS. . . . . . . 42

EFFECT OF REGISTRATION . . . . . . . . 45

AMENDMENT OF REGISTER, SEARCHES . . . . . . 46

CLASSES OF TRADE MARKS . . . . . . . . 47

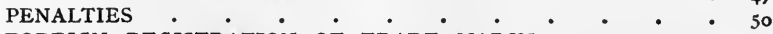

FOREIGN REGISTRATION OF TRADE MARKS . . . . 5 I

COPYRIGHT • • • • • • • • • •

FOREIGN PATENT LAWS ALPHABETICALLY UNDER THE HEAD. ING OF EACH COUNTRY 
Previous Editions

Entered according to Act of Congress,

in the years 1889,1892 \& 1895 respectively, by

W. PHILLIPS THOMPSON,

in the Office of the Librarian of Congress at Washington; Also Copyright in part, $1878,1880,1883$, \& 1886 .

Part of the matter also entered at Stationers' Hall, in 1874, $1878,1883,1886,1889,1892,1895,1898,1904$, of 1908 as " Handbook of Patent Law," and " Handbook of Patent

Law of all Countries."

$A^{\prime \prime}$ rights reserved. 


\section{HANDBOOK OF PATENT LAW}

\section{GREAT BRITAIN AND IRELAND.}

(Patent and Design Acts 1907 and I9I9.)

(Trade Mark Act, I9I9.)

Population, 45,600,000.

Kinds of Protection.

There are four species of industrial protection :-

r. Patents of invention for sixteen years, ${ }^{*}$ and Patents for additions to and improvements on inventions covered by prior patents and to expire with them.

2. Registration of ornamental designs for five years, renewable for five and possibly five further years.

3. Registration of trade marks for fourteen years, renewable again and again, for fourteen years, and "Patent Medicines."

4. Copyright of books, music, \&c.

\section{PATENTS OF INVENTION.}

A Patent, or exclusive privilege, to an inventor for a limited period is, in reality, a contract between the Crown, on behalf of the nation at large, and the inventor. The latter gives to the public what it did not possess before-the full details of a new invention; the Crown, in return, gives the inventor the exclusive right, subject to certain conditions, of working that invention for a limited period, at the end of which time the full benefit of the discovery passes to the public.

\section{WHO CAN PATENT.}

Any person or persons, native or foreign, adult or minor (not at the time an alien enemy), provided that he, or they, or one of

* Till I920 they were only granted for fourteen years, but all those remaining in force are extended to sixteen years without any payment or condition, except that patents normally expiring before Jan. x, 1920, are endorsed "License of right." Existing licenses on these patents can, if desired by the holders thereof, be extended to the end of the additional grant of two years, but endorsed "License of right." For meaning of these words see page 8 . Annual taxes are payable on the two years' extension. 
them be the true and first inventor or inventors, or the importer or importers of the invention from abroad, or the executor or administrator (by appointment of a British court) of the deceased inventor, or the assignee of an invention patented abroad, can make application for a patent. A pending application of a deceased inventor can be granted to his executor or administrator within one year of the said inventor's death.

A patent may be applied for by one or more inventors, conjointly with applicants who are not inventors, and in this way a capitalist or other person assisting the inventor, or purchasing an interest in it, before the application-or even a body corporate, such as a limited company-can secure an interest in it. As a rule it is undesirable to make a body corporate one of the applicants, as it is not quite certain whether in such case every member of the said body has not an independent right to use the invention. If, however, a patent be assigned or licensed to a body corporate, the individual members thereof have no separate right.

Now, the question arises, What does the word "inventor" mean? In the time of James I, when the Statute of Monopolies was passed, the generally accepted meaning of the word " inventor " was the man who first becomes possessed of an invention in the realm, either by discovering it himself, or by importing the discovery of another; and most of the earlier patents were for imported inventions. The word is derived primarily, as is well-known, from the Latin in venire, to come in, and the courts, ever since the time of James I, have construed the word "inventor" to mean the individual in the realm to whom the invention has first come, whether by importation or discovery.

In old times it was held unconstitutional for the king to grant a monopoly to a foreigner resident abroad. The Statute of Monopolies made all monopolies illegal except those granted to the true and first inventor thereof, for a new invention in the realm, which " others" (that is, others in the United Kingdom) did not, at the time of grant, use. Monopolies to forejgners abroad were already considered illegal. Hence for many years all foreign inventions were patented in this country as communications to Patent Agents in the country, who thus became the true and first "inventors" or importers as trustees for the real owners and discoverers. Latterly, inventors abroad have taken out patents in their own names, and the office freely grants such, and so far their legality has not been questioned. For the above, and for other reasons, however, it is somewhat safer and better for foreigners residing abroad to apply for patents through a resident in this country as communications. An exception to this is made expressly when the inventor is a citizen of or resident in one of the countries forming the Union 
for the Protection of Industrial Property (see page 22), and the patent is applied for within twelve months of the date of the earliest foreign patent for the same invention and under the rules of the Convention. It must then be taken out in the name of the foreign patentee or his assignee.

Where a patent has been applied for by a resident in this country as a communication from a foreigner resident abroad, and that patent is afterwards assigned to the foreigner (or even a body corporate with his consent), there is no doubt that the latter can legally hold such patent, and carry on actions for infringement thereof, unless he be an alien enemy.

\section{JOINT INVENTION.}

When an invention is the joint production of two minds, it should be patented in their joint names ; for should it be proved that the patentee obtained from another individual a material part of the invention, the patent will be invalid.

Should, however, an inventor employ another individual to perform experiments with a view to making a specific discovery, the discovery so made is, in the eye of the law, made by the employer, and can be patented by him without using the name of the aforesaid employee, the latter being looked upon as merely an instrument employed by the inventor.

An employer has no right or title to the inventions of his employees, except such as those mentioned in the previous paragraph, where the employee has been employed purposely to work out the details of a general idea unfolded to him by his employer. Even should there be a special agreement between master and servant, that all inventions of the latter made during the period of service shall become the property of the former, the patents securing said inventions must be applied for in the name of the employee, alone or conjointly with that of the employer, but can be afterwards assigned to the employer.

Two or more individuals obtaining a patent in their joint names, or joint owners in a patent without a special agreement, are not partners, but each has an equal and co-extensive right to work the patent to his own individual advantage, or to sell or bequeath his entire share, but not a part thereof. He cannot license others, and neither patentee is responsible for the liabilities of the other, but all owners have a joint interest in all royalties received by any one of them. It is very desirable, in all cases of dual ownership, that there should be a definite written agreement between the parties from the start.

A patent can be seized by a sheriff, and in case of bankruptcy of owner it forms part of the estate, and can be sold for the benefit of the creditors. 


\section{WHAT CAN BE PATENTED.}

Any new art, manufacture, or composition of matter, new combination of two or more known things producing an advantageous result, or any new chemical or other process, or improvement on existing processes or manufactures, can be patented.

"In the case of inventions relating to substances prepared or produced by chemical processes, or intended for food or medicine, the specification must not include claims for the substance itself, except when prepared or produced by the special methods or processes of manufacture described and claimed or by their obvious chemical equivalents; provided that, in an action for infringement of a patent where the invention relates to the production of a new substance, any substance of the same chemical composition and constitution is, in the absence of proof to the contrary, deemed to have been produced by the patented process.

"In the case of any patent for an invention intended for, or capable of, being used for the preparation or production of food or medicine, the Comptroller can, unless he see good reason to the contrary, grant to any person applying for the same, a license limited to the use of the invention for the purposes of the preparation or production of food or medicine, but not otherwise; and in settling the terms of such license and fixing the amount of royalty or other consideration payable, the Comptroller is obliged by law to have regard to the desirability of making the food or medicine available to the public at the lowest possible price consistent with giving to the inventor due reward for the research leading to the invention.

"Any decision of the Comptroller under this subsection is subject to appeal to the court."

These, the words of the law, apply only to patents applied for after January I, I920.

If, in the opinion of the Comptroller of the Patent Office, an application cover more than one invention, the grant is refused, subject to an appeal to the Law Officer ; but the applicant has the option of a patent for one of the inventions set forth in his specification on the original application, and of making a fresh application or applications for the others. These, if he desire it, and if they be made within the requisite time allowed, are dated as of the day of the original application, or, under exceptional circumstances, such later date as the Comptroller may direct.

Following the decisions of the Law Officers, the unwritten rule adopted by the examiners appears to be as follows:-Any two or more distinct and very novel or " pioneer" inventions, dependent for their successful operation upon each other, and tending together to produce a new result, can be covered by one 
application, as a combination (if not independent parts of some well-known type of machine or process, as for instance the piston and fly-wheel of an engine) and can even be claimed separately under the same patent for the purposes described; also two or more ways of accomplishing the same result, if they have apparently novel points in common, can be covered by one application, but the office has been much stricter of late, and the practice of the various examiners differs considerably on this matter.

A patent once granted cannot be objected to at law, on the ground of its covering more than one invention.

A new application of a known thing or process can be patented, provided it be not analogous to any known application thereof.

The new combination of two known means to effect an improved result can be patented. Thus, the hot blast and anthracite had both been used separately in the smelting of iron; yet a patent for using the hot blast in combination with anthracite was decided to be valid, the combination producing great industrial advantage.

A patent specification may refer to subject-matter of another prior valid unexpired patent, but the patentee cannot of course work the previous patent without a license from the owner thereof. This license, however, he can generally obtain from the patentee, or (should the latter be unwilling to grant it otherwise) by petition to the Board of Trade and a court, as hereafter explained under the head "Working, etc.," page I7.

\section{WHAT INVENTIONS ARE MOST PROFTTABLE.}

Patents for improvements in the manufacture of machines, small objects, or processes in common use, are usually much more profitable than those for steam-engines, blast furnaces, ships, or other large and costly structures. Bessemer, who made more than a million sterling out of his steel-making patents, is a comparatively rare exception to this rule.

In an official report of a chief examiner of the United States Patent Office appears the following:- "A patent, if it is worth anything, when properly managed, is worth, and can easily be sold for, from ten to fifty thousand dollars. These remarks only apply to patents of minor or ordinary value. They do not include such as the telegraph, the planing machine, and the rubber patents, which were worth millions of dollars each. A few cases of the first kind will better illustrate my meaning.

"A man obtained a patent for a slight improvement in strawcutters, took a model of his invention through the Western States, and, after a tour of eight months, returned with forty thousand dollars $(£ 8,000)$ in cash, or its equivalent.

"Another inventor obtained extension of a patent for a machine to thrash and clean grain, and sold it in about fifteen 
months for sixty thousand dollars $(£ \mathrm{I} 2,000)$. A third obtained a patent for printers' ink, and refused fifty thousand dollars ( $f$ Io,00o), and finally sold it for about sixty thousand dollars $($ (II2,000).

"These are ordinary cases of minor inventions, involving, no very considerable inventive powers, and of which hundreds go out to the Patent Office every year. Experience shows that the most profitable patents are those which contain very little invention, and are often, to a superficial observer, of little value."

Another species of patent, almost always highly profitable, is that of small improvements on existing processes in the arts. Almost all the principal manufacturing firms that have risen and become eminent during the last fifty years date their prosperity from some occasion, when, making an improvement upon the then existing methods of manufacture (frequently only in some insignificant detail), they obtained for a time almost a monopoly of the trade. Thus a firm in Birmingham are believed to have made some millions sterling out of their patent for making screws pointed, so that they may enter the wood more easily.

A firm of London candle manufacturers took out a patent for making the lower ends of candles taper, instead of parallel, so as to more easily fit the sockets, and to this small improvement, " which any fool might have invented," but did not, a large part of their present enormous business is owing.

The patent for making umbrellas out of alpaca instead of gingham realised a princely fortune for its inventor, while the simple patented idea of heating the blast in iron smelting has certainly increased the wealth of this country by hundreds of millions.

In most cases where men have risen to eminence through inventions, they did not stop at a single patent, but kept on improving, and buying also the improvements of their workpeople and others. Howe, the inventor of the sewing-machine, was an exception. He made a large fortune out of that one invention, and left improvements on it to others. One firm among his licensees, Wheeler and Wilson, by taking out fresh patents, and working them, are said to have made more than one million dollars $(£ 200,000)$ a year net profits, during the continuance of Howe's patent, after paying the owner of said patent his magnificent royalties.

\section{RIGHTS CONFERRED BY PATENTS.}

A valid patent gives its owner the sole right, for sixteen years (subject to his paying the taxes at the end of the fourth and subsequent years), of making, using, selling (or importing) the article or process patented, in the United Kingdom of Great 
Britain, Ireland, and the Isle of Man, and on the adjacent seas, but not in ships of those countries or colonies that grant similar exemption to British shipping in their waters. This sole right is, however, subject to the exceptions set forth in the articles "Working, etc.," page I7, and "Revocation of Patents," page 27.

The period of sixteen years can sometimes be prolonged (sce page 20). Most existing patents have been granted for only fourteen years, but the Act of I9I9 extends them to sixteen.

It is an infringement of the patentee's rights to manufacture for one's personal household use.

\section{PATENT AGENTS.}

The Government does not guarantee anything in the patent, but simply gives the patentee a right to the exclusive use of his invention, subject to certain limitations, and so long as nothing against the validity of his patent shall be proved. It is a common mistake to suppose that "a patent is a patent," and that so long as an inventor has his letters patent he has a good and sufficient title-deed. It is, indeed, an undoubted fact that a vast number of the patents at present existing will not " hold water" (generally through defective drawing up, or from want of novelty). This is owing in a great part to the employment of " cheap agents," and inventors doing their own patenting. Nothing, indeed, in the whole range of law requires such varied skill to draw up as the final specifications of patents. With other law documents there are books of precedents to keep one straight. This is not and cannot be the case with patent specifications, and without great care and skill and scientific knowledge on the part of the man who draws these up, they are almost certain to be valueless. It is for this reason that solicitors usually decline to take out patents, but refer their clients to men whose special business and training qualify them to draw up these documents.

Patents are frequently upset when attacked because it is the bad patents that are attacked.

So great had this evil of incompetent practitioners become, that in I888 an Act was passed allowing no fresh individuals to advertise themselves as "Patent Agents" without first passing an examination. This has been very beneficial, but the first effect of the Act was the registration of a large number of inexperienced men anxious to come in without examination. Unfortunately, the Act of I888 did not forbid unauthorised persons from practising, and large numbers took advantage of this flaw. All these (unless at some time guilty of misconduct), by the law of I9I9, can be registered within a given time. It is an offence ( $£_{20}$ penalty) for a non-registered person now to practise. Nearly all Patent Agents of any standing are members 
of the Chartered Institute of Patent Agents, and are known as Chartered Patent Agents, and the Chartered Institute has now the control of the register, and can bring actions to have agents removed from the register' on showing very good cause.

No single individual, however learned, can have an accurate theoretical acquaintance with every branch of industry or science, or what has been already patented therein, let alone the special knowledge of patent law and practice required in a Patent Agent. To meet this difficulty, the larger firms of Chartered Patent Agents have several scientific heads of departments. One takes the chemical patents, another the general mechanical, a third the electrical, a fourth the textile, while a fifth may devote himself to trade marks and designs, and so on.

\section{PROCEDURE FOR OBTAINING A BRITISH PATENT.}

An invention can be provisionally protected for nine months, and this provisional protection can be changed at any time during said nine months into a complete patent for sixteen years (subject to forfeiture in case of non-payment of certain stamp duties. See page I9). An invention can also be protected by a complete application at the outset, instead of by a provisional one, in which case no provisional application is required. The specification in a provisional application merely describes the nature of an invention, without giving it in all its minute details, or making any distinct claim. Nothing however can be claimed in the complete specification not foreshadowed in the provisional. A complete specification must, as its name implies, fully describe the invention, and must clearly and distinctly point out exactly what parts are new and claimed as the actual invention protected, and is a document requiring the highest skill and long experience to draw up efficiently.

The following are the respective advantages of filing a provisional or a complete application :-

\section{Provisional.}

The invention may, from the date of application, be used and published without prejudice or injury to the patent when granted, but the inventor cannot prosecute infringers till he obtains his patent, nor can he even then obtain damages for infringements made previous to the acceptance of his complete specification.

$\mathrm{He}$ can even make fresh provisional applications for cognate inventions or improvements to be completed in the same complete specification without extra fees

\section{Complete.}

After the acceptance of the complete application, and until the date of sealing the patent, or the expiration of the time for sealing, the applicant has the like privileges and rights as if a patent for the invention had been sealed to him on the date of acceptance of his application, except that he cannot prosecute infringers until the actual patent is granted to him. He can then claim damages for all infringements subsequent to the date of the acceptance of his complete specification, 
when completing, but in such cases the claims for the fresh matter are considered as operative only as from the date of the provisional specification on which they are based.

The description of the invention is kept secret until the acceptance of the complete specification, and should, from any cause, that specification be not accepted, it is not published at all, and the applicant can make a second application at any time afterwards, if in the meantime the invention be not published.

Abundant time is left, after protecting in England, for filing foreign patent applications, and for the inventor to get (by applying for a patent in Germany or the United States) the very exhaustive report of the examiners of those countries respectively on the novelty of the invention (a very useful document), before deciding what claims to make in the complete British specification.

This mode of procedure costs a little more for the complete patent than the other, but only the small costs of provisional protection need be paid when making the application, and the remainder when filing the complete specification.

During the provisional stage the inventor can file fresh provisional specifications for cognate inventions on the same subject, and complete both in a single complete specification.
The claims in the complete specification cannot be added to after acceptance, though they may be curtailed or palpable clerical errors corrected, and in some cases explanations made. These alterations entail extra expense.

The specification is printed and published shortly after the application has been accepted (unless the applicant specially petitions to the contrary), and owners of prior provisional protections still running, seeing the invention, can draw their claims wider to cover it, and thus rob the later inventor.

Patents for several foreign countries, in order to be valid, must be applied for before the publication of a complete specification in England.

The complete specification is usually at once examined as to novelty, and there is no hurry or chance of loss of date in getting the case accepted. This is the greatest advantage of all.

A slight saving may be effected by this method of application, but the entire cost of the patent, with the exception of the final fee, has to be paid at once.

It is much more difficult and expensive to get a cognate invention engrafted into the complete specification, and possible only then if the complete has not yet been " accepted."

\section{PROVISIONAL PROTECTION.}

An inventor or inventors, or the legal representatives of a recently deceased inventor, with or without other individuals joining him or them in the application, can obtain provisional protection by application, prepared in due form, deposited at the Patent Office. Skill and experience are required to properly draw up the specification, and inventors, as a rule, will find it best to employ an experienced Patent Agent for this purpose.

While the law of 1852 was in force we recommended all inventors to have a search made as to novelty before protecting. Now, however, since protection can be obtained so cheaply, and the Government make a search when the complete application is filed, when any non-novel claims can be cut out or amended, 
and as under the present law disclaiming (as will be afterwards described) has become almost a matter of right, instead of favour, it will usually be found the wiser plan to obtain immediate protection where there is a reasonable ground for believing the invention to be valuable and new. During the nine months that next ensue (or ten months with a small fine) the inventor can freely work, sell, and show his invention without injury to his rights, provided he, during the period allowed, files a complete specification, and he will have ample opportunity of finding out whether his invention be new, or to what extent it is old, especially if he introduce it to the trade at large, or apply for a United States or German patent, in which case the Government of that country will make a search as to the novelty of the invention and furnish a full report.*

The patent dates from the day when correct papers (see below) are deposited in the Patent Office, or, if correctly addressed and officially posted to it, from the hour when such papers should in the ordinary course of post have been delivered, even though, through some accident, the parcel be delayed or lost in transmission.

Under provisional protection the inventor cannot sue infringers until his patent be sealed, when he can obtain damages for all infringements made after the acceptance of his complete specification. The industrial use or sale without license of a patented machine after completion of the patent, though the machine or article was made before the acceptance of the complete specification, is an infringement of the patent. A patent for the invention applied for and completed by another party during the provisional protection does not prejudice the patent afterwards obtained on such provisional protection, except when such patent has secured a prior date under the Union for the Protection of Industrial Property (see "International Protection," page 22).

If, while the invention is provisionally protected, the applicant makes an improvement thereon, he can take out a second provisional protection for it, and combine both provisionals in one complete specification. The claim for the new matter will date as regards priority from the date of first filing a description of it at the Patent Office. If new matter not in any provisional be otherwise inserted in the complete specification the Comptroller can require its elimination or the date of the patent to be altered to that of the filing of the complete specification, or he can grant a patent for the matter found in both the provisional and complete specification and allow the applicant to file a second application for the extra matter to be dated as of the date of the original complete application.

* The British Patent Office search is very good as far as it goes, but it only extends to the British patent specifications filed within the last past fifty years. 


\section{FIRST EXAMINATION.}

Each application, as soon as practicable after filing, is referred to an examiner, who ascertains and reports to the Comptroller, (Ist) whether the nature of the invention has been, in his opinion, fairly described; (2nd) whether the application, specification, and drawings, if any, have been prepared in the prescribed manner ; (3rd) whether the title sufficiently indicates the subject-matter of the invention, and (4th) whether there be more than one invention set forth in the application. If the examiner reports against the application on any of these enumerated points, the Comptroller may require the application, specification, or drawings to be amended before he proceeds with the application, and, if the case be very imperfect or informal, has power to only grant protection from the date when the required corrections have been made. The Comptroller does not, however, exert this power except in extreme cases.

The applicant may appeal against the Comptroller's decision to the Law Officers of the Crown.

If an appeal be made, the Solicitor-General hears the applicant or his agent and the Comptroller, and decides whether the application should be allowed, and upon what terms.

The examiners are nearly always experts in their departments, and very able and courteous gentlemen, ably seconding the Comptroller in his determination to make the examination system the striking success which it has become. Towards the end of the war, however, many of the best examiners were taken away to assist other departments of the Government, and the Patent Office has suffered in consequence, but is gradually getting straight again.

The power of ordering amendment might be open to serious abuse. There have, indeed, been cases where alterations made at the instance of examiners have increased the scope of the original invention possibly to the detriment of the subsequent applicants. These alterations are kept secret, and only the specification as actually amended is published. The law needs a radical alteration here, as it opens a door for fraud, which under the old régime was taken advantage of by unscrupulous patentees. All that men can do is done by the present examiners to prevent abuse, but the only safe rule (in force in nearly all other countries) is that a document once filed can never be altered, but that its contents can be qualified by a second document, dated as of the day it is filed, stating the amendments demanded or made. The published specification should be printed with these alterations shown, or, as in America and other countries, the original papers be open to inspection by the public. Where, indeed, amendments or disclaimers are made after the sealing of the patent, this rule is usually carried out in England. 
If the application be considered in order, it is allowed to date from the day of application (except in the cases above mentioned and somewhat similar ones hereafter mentioned in connection with the second examination), the applicant is notified, and the provisional specification is kept secret till the acceptance of the complete specification.

The provisional application being allowed, the next step in obtaining a patent consists in depositing-

\section{A COMPLETE SPECIFICATION.}

This must be filed within the nine months of provisional protection-or the month following on payment of a fine-or the application is held to be abandoned and void.

But, if desired, the complete specification, with (if necessary) drawings and specifying the features of the process or apparatus claimed as novel, can be lodged in the first instance instead of a provisional one.

The complete specification, whether in pursuance of a provisional application or not, must describe the invention fully and in detail, and the best mode known to the inventor of carrying it out, and the invention claimed must be accurately and particularly defined. If drawings be useful or desirable for the better understanding, they must be furnished, drawn in an artistic manner, in accordance with the rules.

The specification must also clearly distinguish and point out exactly what is new and what is old in the invention; and should anything claimed as new be proved hereafter to have been known, or be entirely useless, or in public use in the realm previous to the application (except when surreptitiously obtained from the inventor or merely exhibited in an international exhibition as hereinafter set forth), the claim can be declared void. (There is an expensive remedy for this, however, as will be afterwards explained under the head "Disclaimers," page 2o.)

An invention must be fully and unreservedly explained in the specification, without concealing any part, and so that any competent workman, conversant with the branch of manufacture to which it is nearly related, could work the invention without any other instructions than those the specification affords; otherwise the patent will not be valid.

Any deceit in the specification invalidates the patent (as, for instance, if an ingredient be mentioned as forming an essential part of a compound, which ingredient, however, the inventor knew was of no manner of use in it). Similarly, if it be found that the inventor concealed any part of his invention, or set forth an inferior mode of working, knowing of a superior one, his patent is void on the ground of bad faith.

In the case of communications from abroad, however, no 
evidence of deceit or fraud on the part of the communicator can invalidate the patent. But if it be proved that the person to whom the invention is communicated and who takes out the patent had made a concealment of this nature, or bas obtained the invention by fraud, the patent can be upset at law.

Patents taken out under the convention (see page 22) are dated as of the date of the foreign patent, and one year after this date the applications are made public whether allowed or not.

\section{SECOND EXAMINATION.}

Where a complete specification has been lodged after a provisional, it is referred to an official, who examines it to see if the invention claimed in the complete is the same as that set forth in the provisional specification (or specifications, if there be more than one). All complete specifications are examined to see whether they have been described in whole or in part in any prior British specification published during the immediately preceding fifty years. To assist the examiner in this matter, the Comptroller may require the applicant to supply samples in the case of chemical inventions. If the invention be found to be novel at the date of the application, clearly described and claimed, and the claims all based on the provisional specification (or specifications) being completed, and the documents explicit and in accordance with the rules, and not embracing more than one invention, the specification is accepted unless the applicant has unreasonably delayed. If, however, the invention be anticipated in whole or in part, or otherwise objectionable, the applicant has the option of :-

I. Amending the specification, in which case it is again examined, and possible again objected to by the examiner, and so on for several times, or

2. Inserting a reference to such prior specification in his own, or

3. Appealing against the examiner's decision, or

4. If there be more than one invention, confining the specification and claims to one invention, with the option of putting in a further application or applications for the matter struck out to bear the date of the original application or the date on which the fresh application or applications are filed, as preferred; but the protection only dates from the date so chosen.

The official examination is not an absolutely complete one, as it is only British patents of the previous fifty years that are examined, and not, as in Germany and the United States, foreign patent specifications and books also, which, if they contain the invention and are open to public inspection here, are equally fatal to the validity of an English patent.

If the examiner be not satisfied, the Comptroller hears the 
applicant if the latter desire it, and then determines whether a reference to any, and if so, what, prior patents ought to be made in the specification by way of notice to the public. If the examination shows that the invention is completely forestalled by a single prior patent, the Comptroller can refuse the patent if he thinks fit, subject to appeal to the Solicitor-General.

It is extremely rare for the Comptroller to exercise this discretionary power.

If the examiner decides that the complete specification goes beyond the provisional one (or ones) in claiming new matter, such new matter can still be made the subject of fresh application as of the date when the complete specification was filed; or the Comptroller, with the applicant's consent, can cancel the provisional specification, and treat and date the case as applied for on the day when the complete specification was filed.

It is no part of the examiner's duty to examine into the validity of the specification or the novelty of the invention, otherwise than as regards the immediately preceding fifty years of British complete patent specifications, but to pass the application for hitherto unpatented matter common to both provisional and complete.

Should considerable delay have been caused by amendments, the Comptroller may at his discretion seal the patent with a later date than that of application.

If the complete specification be not accepted within eighteen months from the date of the application (unless delayed by appeal to the Law Officer) protection ceases, and the invention becomes public property. The Comptroller is, however, allowed at his discretion to, and always does when so required, extend the time one, two or three months on payment of fines.

\section{HEARING AN OBJECTION.}

As official citation on the actual printed specification of one or more patents as anticipations is very injurious to the value of a patent, it is very desirable that all prior specifications brought forward by the examiner should be carefully considered and argued and got rid of, or the specification amended.

An appeal can be made from the decision of the Comptroller to the Solicitor-General.

\section{ADVERTISING.}

When the complete specification is accepted by the Comptroller, it is (unless delayed on petition to not exceeding eighteen months from date of application or twenty-one months with a fine) immediately advertised as open to public inspection, and any one can examine it at the Patent Office, or obtain a copy of it on paying the cost of transcribing. 
It is also put in the hands of the King's printers and printed in due course, usually about three weeks after acceptance. Copies can then be purchased by the public at low rates.

\section{OPPOSITION.}

During the ensuing two months after acceptance of the complete specification and practically for two years from the date of application even after sealing, any person is at liberty to oppose the grant of the patent, or apply for the revocation of the patent if already granted, on the ground that the applicant has obtained the invention from him, or from some one of whom he is the legal representative, or that it has been the subject of one or more prior patents, dated not more than fifty years prior to the date of the application being opposed, or has been published in the United Kingdom prior to the application by any document available to the public, or that the invention has already been claimed in another complete specification which was not published at the date of application for the patent on the said invention the grant of which is opposed, but which was filed at an earlier date and which consequently will be of prior date when granted, or that it includes an invention not set forth in the provisional specification for which the opponent has since the filing of the provisional specification applied for a patent, or on the ground that the invention or its mode of action is not sufficiently or fairly described in the complete specification, or that the invention is claimed in a specification which, though filed after the date of the application opposed, will when granted, by reason of the convention, take a date earlier than such application. A patent specification using words untrue or injurious to another is held to be "unfairly described." If an opposition be entered, the matter is adjudicated upon by the Comptroller of Patents, but the parties have the right of appeal to the Attorney- or Solicitor-General in the case of an unsealed application, or to a court if the patent be sealed already. If the opposer or appellant have no domicile or place of business in the realm, he may be required to give security for costs or be non-suited.

If the points in dispute involve technicalities beyond the knowledge of the Law Officer, the latter is allowed to call in a man eminent in the line of business to which the invention relates to assist him as assessor. This, however, he very rarely does. The Comptroller and Law Officer can make either party pay a part or all of the other's costs, as they may think just. The costs under the Comptroller depend on the amount incurred and are assessed by him. Usually the Law Officer allowed, under the old law, from three to ten guineas, but it is expected these costs will now be raised, as they were much too low. 
In these oppositions it is not necessary to employ a barrister, and, indeed, with few exceptions (i.e. where counsel makes a speciality of patent work), a good patent agent makes at these hearings a better advocate than a barrister.

In oppositions the person who first makes an application for the patent is held, in default of conclusive evidence to the contrary, to be the first inventor, and, though the same matter may be covered by both patents, unless the earlier applicant be proved to have taken it from the other, he is adjudged sole owner of the new matter common to both patents (if claimed by him), and the second cannot use it without the first's permission.

Two or more inventors effecting the same result, but by different means, can each obtain a valid patent for his mode of procedure, provided said modes are substantially different.

A patent granted to the true and first inventor is not invalidated by a prior application made in fraud of him, nor by any sale, publication, or working of the invention made subsequent to the fraudulent application, and during the period of provisional protection; and where a patent has been revoked or cancelled by order of the court on the ground of fraud, the Comptroller of Patents or the court may, on the application of the true inventor made in due form, grant the true inventor a patent in lieu of and bearing the date of the fraudulent patent; but the new patent will be only issued for the remainder of the term for which the revoked patent was granted.

This clause is construed not to apply to inventors resident abroad taking out patents as communications. In a case where A. in New York had invented a machine in I886, and in I887 B. entered his employ, saw the machine, and forwarded the particulars to C., a British Patent Agent, who took it out as a communication from B., the day before D., another Patent Agent, applied for it as a communicant from A., it was decided that as $A$. and $D$. could not prove that $C$. (the agent) had obtained the invention dishonestly, the latter was the "true inventor" and the fraud committed by B., the communicator abroad, was immaterial to the case.

Also in a case where B., a person abroad, was shown to have stolen the invention from a subsequent applicant, also resident abroad, the officials allowed the patent to the first applicant (B) on the ground that they cannot take cognizance of a fraud committed outside the realm. The courts, however, possibly may grant justice in these cases, but no such case as yet been tried.

An application being allowed is immediately published, and is open to opposition for two months.

Since the year I9I5, patent applications receive a serial number, such as No. I234/I920, but directly they become accepted they receive a second number comprising six figures, 
such as No. I23,456, under which number the patent is to be subsequently known.

\section{SEALING.}

If no opposition be entered, or the case be decided in favour of the applicant, the patent is passed for sealing with the Seal of the Patent Office, and if sealed, is dated as of the day of the original application, except under special circumstances mentioned under the heads First and Second Examination. The patent is granted for sixteen years from its date. Patents granted for fourteen years, and which had not expired on January $\mathrm{r}, \mathrm{I920}$, are by the new law extended to sixteen years, but if expiring before January Io, I920, shall for the extension be endorsed " license of right" (see "Working, etc.," below).

It will not be sealed, however, except on formal application and payment of the sealing fee, within the period allowed.

Where, however, the sealing is delayed by an appeal to the Law Officer, or by opposition to the grant of the patent, the patent may be sealed at such time as the Law Officer may direct, otherwise it must be sealed within eighteen months of the date of application (or twenty-four months where the time for filing or accepting the final specification has been officially extended); after this it cannot be sealed except under special circumstances when by payment of fines an additional term up to three months can be obtained. If the person making the application dies before the expiration of eighteen months from the date of application, then the patent may be granted to his legal representatives, and sealed at any time within twelve months after the date of his death.

\section{PATENTS OF ADDITION.}

Inventions for improvements on a then existing patent by the same applicant can be obtained, to expire with the original patent.

On these patents no renewal taxes are payable at the end of the fourth and subsequent years. A patent of addition once granted cannot be upset on the ground that it ought only to have been granted as an original patent.

\section{"WORKING" AND " ABUSE OF MONOPOLY RIGHTS."}

Any person interested may bring application in the form of a complaint to the Comptroller either:-

I. That a patent, after the expiration of four years from its date, being for an invention capable of being worked in the United Kingdom, is not being so worked on a manufacturing scale, or 
2. Is being prevented from being so worked through the importation of the patented article by the patentee or persons against whom the patentee has not taken proceedings for infringement, or

3. That the demand for the patented article in the United Kingdom is not met on reasonable terms, or

4. If by reason of the patentee refusing to grant licenses, trade is prejudiced, and that it is to the public interest that a license or licenses should be granted, or

5. That the conditions under which alone the patentee will grant licenses are unfair.

The Comptroller on hearing the parties and being convinced that there has been an abuse of monopoly rights may order the patent to be endorsed "license of right," whereupon:-

(a) Any person shall at any time hereafter be entitled to a license on equitable terms for all parties, to be settled by the Comptroller, but to include the terms and conditions set forth hereinafter under heading $(b)$ and $(c)$.

(b) The license may be framed so as to prevent the licensee from importing the patented article into this country from abroad.

(c) If the Comptroller be satisfied that the objects of this " abuse of monopoly" clause cannot be attained by the exercise of these powers, he may order the patent to be revoked as may be specified in the order, unless in the meantime such conditions as may be prescribed in the order be fulfilled. The Comptroller can extend the interval specified.

(d) If the Comptroller consider the provisions of this section will be best attained by making no order, he can refuse the application for a license and decree costs as he sees fit.

(e) If the exigencies of finding capital make it in the opinion of the Comptroller, desirable to grant an exclusive license, the license shall be so framed as to give the patentee the maximum royalty compatible with the licensee working the invention on a commercial scale and at a reasonable profit, and to guarantee the patentee a minimum yearly sum as royalty, and the license shall be revokable by the Comptroller if these conditions be not carried out. The Comptroller in deciding who should have an exclusive license shall prefer (without good cause to the contrary) an existing licensee. An exclusive license shall take away the patentee's right to use the invention. All applications for compulsory licenses shall be published in the Illustrated Official Journal (Patents), and all parties interested shall have the opportunity of delivering statements and counter-statements. The Comptroller can then, as he sees best, discuss the application or appoint a hearing, when both sides can give evidence as in a court of law.

In a case of an infringement of a patent endorsed " license of right " if the infringing defendant is willing to take a license 
the case to the satisfaction of the Comptroller, and paying the prescribed fees.

\section{PROLONGATION.}

At the expiration of sixteen years from the date of a patent, the invention becomes public property unless the inventor can obtain a prolongation of his patent from the Supreme Court. This can sometimes be obtained if the invention be a very important one, and the inventor has used due diligence in working it, has not received a fair and reasonable profit for its use, and still has an interest in the patent. But all this he must prove to the satisfaction of the court.

The application has to be made and duly advertised at least six months before the expiration of the period for which the patent was granted, and the applicant must be prepared with elaborate statements of accounts and proof of their correctness. Any profits obtained by the applicant on foreign patents for the same invention should also be set forth. Any interested party can oppose the grant of such extension, and the court has power to grant costs to either party.

When, by reason of war between this country and another, the patentee as such, not being an Alien enemy, has suffered loss or damage, including loss of opportunity of dealing in or developing his invention owing to his having been engaged in work of national importance connected with such war, he can apply to the court by " originating summons " for an extension, and the court, in considering its decision, may have regard solely to the loss or damage so suffered by the patentee.

\section{DISCLAIMERS AND AMENDMENTS.}

It very frequently happens that something has been claimed in the specification that was unpatentable, or without utility, or utterly unworkable, or which was in the public use or published in this country before the date of application; or there is some error or obscurity.

Such a defect often makes the patent invalid. When, therefore, a patentee finds such a flaw, he should immediately apply for leave to amend his specification, including, if necessary, the drawings forming part thereof, by way of disclaimer, correction, or explanation, stating the nature of such amendment and the reasons for the same.

The request and the nature of such proposed amendment must then be duly advertised in the prescribed manner, and at any time within one month from its first advertisement any interested person may give notice at the Patent Office of opposition to the amendments. 
Where such notice is given, the Comptroller hears both parties (or if there be no opposition he examines the documents, and if necessary he hears the applicant), and then decrees whether, and subject to what conditions, if any, the amendment shall be allowed, subject to an appeal to the Law Officer.

The Law Officer, when appealed to, hears the applicant and opponent, if any, if in his opinion the latter be entitled to be heard in opposition, and ratifies, alters, or reverses the decision of the Comptroller as he may consider just, with or without costs.

If the appeal be by an opposed applicant against the decision of the Comptroller, the Law Officer hears both the parties and the Comptroller. From the Law Officer's decision there is no appeal.

In case of a disclaimer, the judge cannot grant damages for infringements prior to the date of the disclaimer unless he is satisfied that the original specification was drawn " in good faith and with reasonable skill and knowledge," and it is very rarely that a judge is satisfied of this when a disclaimer has been made.

No amendment can be allowed that would make the specification, as amended, claim an invention substantially larger than or substantially different from the invention claimed by the specification as it stood before amendment.

An amendment, too, which will reduce a patent from a large field of invention down to some insignificant detail in that field is generally refused. Thus where a man claimed an improved process of, and apparatus for canning meats, and it was shown that the entire apparatus and process were old except a special arrangement of lid, a patent was refused for the latter, though a new and useful part of the original invention.

Leave to amend is conclusive as to the right of the party to make the amendment allowed, except in case of fraud; and the amendment, in all courts and for all purposes, is deemed to form part of the specification.

The foregoing provisions for disclaiming do not apply when, and so long as, any action for infringement or other legal proceeding in relation to a patent is pending.

In an action for infringement of a patent, and in a proceeding for revocation of a patent, the court or a judge may by order allow the patentee, subject to such terms as to costs and otherwise as the court or a judge may impose, to disclaim for the purpose of such action any part of the invention specified in such order, and give the disclaimer in evidence.

This clause is, however, of little use, as the judges almost invariably make it a condition of allowing the disclaimer that all the costs of the action up to that date be paid by the patentee. As, too, the disclaimer is restricted in this case to the actual matter at issue, it is generally best, if a disclaimer be necessary, 
to abandon the action, pay the costs, make the disclaimer, and commence a fresh action. See also "Legal Proceedings," page 30 .

\section{PRINTED COPIES.}

Printed copies of the specifications and drawings (with disclaimers, if there be any) of all British patents still in force (but not of abandoned provisional specifications of later date than I883) can be obtained at a small price if in print. Copies of all patents were formerly kept in stock, but a former Comptroller destroyed all but a limited number of copies of each specification; and now it is impossible to obtain printed copies of many of the early patents, especially those that are of value and in demand, except by ordering six copies, in which case the Government will usually reprint and supply them in a few days' time at a very reasonable charge.

The Patent Office have, however, recently made arrangements to supply photo-copies of any patent specification or document in the Patent Office Library at reasonable prices.

\section{COMPULSORY LICENSES.}

See page I7, Working and Abuse of Monopoly Rights.

\section{RIGHTS OF THE CROWN.}

The Crown by itself, or its agents, contractors, or others duly authorised, has also the right of using the invention for any Government department, and of requiring the invention to be kept secret, on terms agreed upon between the inventor and the Government officials, ratified by the Treasury ; or (if no satisfactory agreement can be come to) on terms as settled by the court or arbitrator.

\section{INTERNATIONAL PROTECTION.}

An international Convention or Union for the Protection of Industrial Properties exists between the following, viz.: Great Britain, Austria, Australia, Belgium, Brazil, Ceylon, CzechoSlovakia, Cuba, Curaçoa and Surinam, Denmark, Dominican Republic, France, and its colonies, Gambia, Germany, Greece, Holland and its Colonies, Hungary, Italy, Japan, Malta, Mexico, Morocco, New Zealand, Norway, Poland, Portugal, Serbia, Seychelles, South Africa, Southern Nigeria, Spain, Sweden, Switzerland, Trinidad and Tobago, Tunis, and the United States of America. A similar treaty exists between Great Britain on the one side, and each of the following States on the other, viz. : Paraguay and Uruguay, as regards patents, trade marks, and 
designs, and Ecuador and Roumania as regards designs and trade marks only. Canada also gives the advantages of the convention to British patentees, but Canadian subjects have not reciprocal rights, as Canada is not an adherent to the Union.

The first application for a patent for an invention in any of the countries of the Union procures to residents or to persons having industrial commercial establishments here, or in any other State of the Union, protection for twelve months in the rest of the Union. This period of priority begins with the date on which the applicant lodged his application for the original patent, and not from the date of the acceptance, and foreign patents should be applied for before the lapse of this protection.

This protection is much lessened in value in most of the European countries in that if any one begins manufacturing the invention, or making bonâ fide arrangements to begin the manufacture, in the realm before the protected patentee applies for a patent in that country, he can go on using the invention during the entire duration of the patent without paying royalty.

The complete application by a foreigner under the convention for a patent in Great Britain must be made in the case of patents (with a special form) within twelve months of the application abroad, and in the case of designs and trade marks within four months of the application abroad, if right of priority be required, and it must be restricted to the exact matter already protected abroad, and the patent is dated as of the day of application in the foreign country. These privileges are now extended to patents applied for in many countries since August I, I9I3, if applied for within six months of the signing of the Treaty of Peace after the great war (Jan. Io, I920).

\section{NOVELTY.}

An invention to be patentable must be unknown to the public in the United Kingdom at the date of the patent application, or during the priority rights granted under the convention or treaty aforesaid. It may, however, have been publicly known and used in foreign countries or colonies only, before the date of application. The sale or public exhibition of articles made in accordance with the invention in any portion of the British Isles, or a complete and accurate description of it in a journal or book, printed or circulating in the kingdom before such date, would invalidate a patent. Copies of the specifications and drawings of American and of some Continental patents are now forwarded to the British Patent Office Library, where they are open to free inspection. This constitutes a legal publication, though they may not have been examined by the public. If, however, the invention be not so sufficiently described as to enable a man, skilled in the line of business to which it relates, 
to work it successfully without experiments or invention on his part, such a partial or defective publication will not invalidate a patent afterwards applied for.

The possessor of an invention, specimens of which he had sold or used publicly, or exposed for sale before being protected by an application for a patent at home (or abroad under the circumstances above set forth on page 22) cannot validly patent it; nor (it is generally thought, but the point is not absolutely decided) can any one obtain a sound patent for a process which he has already used secretly for a period of years, and sold the produce thereof in the realm. A patent is not, however, now held invalid by reason only of the invention having been taken from the inventor and published without his knowledge or consent, and if as soon as the inventor learns of the publication he applies for protection with reasonable diligence.

Describing an unprotected invention in a paper read before a learned society does not nullify the right to afterwards patent it, but it is a very dangerous act, as any hearer or reader of it in the society's transactions could make it public immediately after, sufficiently to invalidate a patent afterwards obtained.

Further, the clause is inoperative unless the inventor duly notifies the Government before reading the paper and on a $£ \mathrm{I}$ stamp.

Experimenting on the invention before patenting, if every reasonable precaution has been taken to keep it secret, and the working has not been for profit, does not invalidate a patent afterwards obtained. Thus it was decided that where a machine for laying cables had been used for laying a single cable, and, proving a great success, was patented on the return of the ship, there had been only an experimental use insufficient to entail the invalidity of the patent, it being impossible to ascertain whether it could usefully perform its work without a trial. On the other hand, the use of a newly invented crane for five months in the owner's yard, which was open to the railway and to the view of customers calling on business, was held to be a publication; as five months was far more than sufficient time to test it, and the continued use was for profit, and not for the purposes of experiment.

The prior publication of an invention which, if it had been made subsequent to the date of the patent, would be considered a clumsy colourable imitation for the purpose of effecting the same result, does not invalidate the patent by anticipation, but in the practice of some of the Patent Office examiners such publication would be held fatal to the grant of a patent, if such publication was in a prior published patent specification.

Similarly a prior unsuccessful and abandoned experiment by a third party, even though it embraces all the principles of the invention, is not sufficient to invalidate the patent afterwards 
obtained. The imperfect publication of an invention in an abandoned provisional specification of a third party has been held not to invalidate a subsequent patent for the same invention; and in order to prevent abandoned provisional specifications from interfering any more with subsequent applications, and for other reasons, a short Act was passed in 1885 requiring the Comptroller to keep such specifications secret from that date. This Act practically cuts off from the public all abandoned provisional specifications entered since the Act of 1883 , as very few of these were published at the time of the passing of the said Act.

\section{EXHIBITIONS.}

The exhibition of an unpatented invention at an industrial or international exhibition, certified as such by the Board of Trade, or the publication of the invention during the period of the holding of the exhibition, or use of the invention by others elsewhere without the knowledge or consent of the inventor during the period of exhibition, will not invalidate the subsequent patent, provided the inventor, previous to exhibiting, gives due notice at the Patent Office of his intention to so exhibit, and provided he applies for a patent within six months of the date of opening the exhibition. As, however, provisional protection is now so very cheap, and expensive litigation might result before the inventor obtained his rights, if another applied for a patent during the period of exhibition and prior to patenting by the original inventor, this clause in the law is of very doubtful advantage.

\section{UTILITY.}

In order that a patent may be sustained, it is essential that it should be useful ; but this point, though usually all-important as regards its value to the inventor, is never investigated by the officials when examining an application with a view to granting a patent.

\section{PENALTIES.}

Where any person claiming to be the patentee of an invention, by circulars, advertisements, or otherwise, threatens another person with legal proceedings in respect of an alleged infringement of the patent, any person or persons aggrieved thereby may bring an action against him, and may obtain an injunction against the continuance of such threats, and may recover such damage (if any) as may have been sustained thereby, if the alleged infringement to which the threats related was not in fact an infringement of any legal rights of the person making such threats. This section does not apply if an action for infringement be commenced and prosecuted with due diligence. 
Any person who represents that any article sold by him is a patented article, when no patent has been granted for the same, or describes any design or trade mark applied to any article sold by him as registered which has not been registered, and in the case of a design, marks it as registered after the registration has expired, is liable for every offence on summary conviction to a fine not exceeding five pounds. This enactment has been held to apply even in cases where the article was at the time provisionally protected.

In such latter cases, however, the article can be marked " Provisionally Protected," "Protected under the Patent Act," or "Patent Applied For."

If, too, a person marks articles as patented for which he has only obtained provisional protection, he runs the risk of losing costs in subsequent actions for infringement which he may bring, the infringer making the plea that, seeing the word " patent" on the articles falsely placed thereon during provisional protection, he had made a search and ascertained that they were not then patented, and when afterwards warned that he was infringing the patent, he took no notice, believing the warning to be as false as the original marking was. This is a good defence.

A person is deemed to represent that an article is patented, or a design or a trade mark is registered, if he sells the article with the word " patent," or " patented," " registered," or any word or words expressing or implying that a patent or registration has been obtained for the article, stamped, engraved, or impressed on, or otherwise applied to the article.

It is better to stamp all patented articles with the word "patent," and the number, or if dated prior to I9I6 date also of the patent. See article under head "Infringements of Patents," page 29.

\section{PENALTY FOR USING THE PATENT UNFAIRLY.}

Any contract of license or sale contrary to freedom of trade in other articles than the patented one, or for the continuance of payment of royalties on the patented invention after the patent has expired, is unlawful and void. Except-

(a) A contract whereby a person is prohibited from selling any goods other than those of a particular person.

(b) Where a licensor reserves to himself or his nominees the right to supply or keep in repair new parts, or to supply such articles, apparatus, or machinery as may be necessary for carrying the patented process into effect.

\section{SEARCHING.}

It is frequently requisite to examine the records to see if an invention has been previously patented or is an infringement of an existing patent. 
The cost of a search varies according to the nature of the subject, and whether the particular class of inventions to which the subject belongs is well indexed. Inventions for heating, for steam-engines or boilers, guns, sewing-machines, looms, spinning and electrical appliances, are usually the most troublesome to search through, often taking, with the ordinary published indexes only, a fortnight's hard work. In all the large cities and towns in the British Isles complete sets of the British patent specifications, from the earliest times to the present date, are kept on file at public libraries, so that inventors and manufacturers may make their own searches; and should they have the requisite leisure and ability, this is decidedly the best course to pursue. When making a search, the inventor should make a record of the numbers and dates of all patents bordering on the invention. This information will be found invaluable when drawing up the final specification. In many cases the best and cheapest way of making a search is to apply for a patent in Germany or in the United States of America. The American and German examiners search through the American, English, French, Swiss, and German patents, and also through standard textbooks. If a patent has already been granted in America for the invention, we can always get a copy of the examiner's original report on the novelty of the invention.

The granting of a patent without reference to any prior patent shows that its claims are in the examiner's opinion not covered by any British patents of the immediately preceding fifty years. When a patent is published we can get copies of all patents cited against it by the examiner.

\section{REVOCATION OF PATENTS.}

Any person within two years of the date of a patent can apply to the Comptroller (if there be no action concerning the patent pending in the courts) to revoke a patent on any ground on which he, or a person of whom he is the successor in title, could have opposed it before being granted. (It can also be revoked by a court if four or more years after its date the patent be worked mainly outside the United Kingdom, but this clause was suspended during the Great War, and for six months after the conclusion of Peace.) The applicant for revocation must, however, bring reasonable evidence that this is the case before the Comptroller will require the patentee to bring in his defence. From the Comptroller's decision there is an appeal. In the case of inventions decided to be mainly working abroad the Comptroller or the court on appeal can grant an extension of time of one, or in some cases two, years to get the invention at work in this country.

An action for revocation of a patent by a court may at any time be instituted by- 
I. The Attorney-General in England or Ireland, or the Lord Advocate in Scotland, or any person authorised by one of these officials.

2. Any person alleging that the patent was obtained in fraud of his rights, or of the rights of any person under or through whom he claims.

3. Any person alleging that he or any person under or through whom he claims was the true inventor of any invention included in the claim of the patent.

4. Any person alleging that he or any person under or through whom he claims an interest in any trade, business, or manufacture had publicly manufactured, used or sold, within the realm, before the date of the patent, anything claimed by the patentee as his invention.

A patent can be revoked, and a defence for an infringement set up, on any one or more of the following grounds:-

I. That none of the patentees is the true and first inventor.

2. That he or they obtained a material portion of the invention from others.

3. That the invention was not new at the date of the patent.

4. That the subject-matter was not patentable.

5. That the patent is more than four years old, and is worked almost exclusively outside the United Kingdom.

6 . That the patentee or patentees did not specify the best mode known to him or them of carrying out the invention; or that he or they inserted or kept back any part or matter with intention to deceive; or that the specification does not sufficiently describe the invention so that a person of ordinary understanding, skill, and knowledge in the trade to which it relates could work it without further information or experiment.

7. That the patentee does not work the invention himself or by licensees sufficiently to fulfil the reasonable demands of the public, and that these cannot be met satisfactorily by the granting of compulsory licenses.

In an action for a revocation of a patent the person seeking to upset the patent must deliver particulars beforehand of the objections and evidence on which he means to rely. These particulars can be amended only by order of the court or a judge, and no evidence can be brought forward against the patent at the trial, except such as is set forth in the particulars previously delivered.

If the patentee finds from the particulars of objections that his patent specification contains claims that are old, or a part or parts that are bad at law, he can, by order of a court or judge, enter a disclaimer, as already described (the legal proceedings being suspended meanwhile), and put in that disclaimer as evidence in his defence in the action instituted to revoke his patent. 
The defendant (owner of the patent) is entitled to begin, and give evidence at the hearing in support of the patent, and also to reply, if the plaintiff gives evidence against the validity of the patent, subject to appeal to the court.

In an action for infringement of a patent the defendant can allege as a ground of his defence that the patent is bad, and apply for its revocation as a kind of counterclaim.

A patentee can avoid the costs of an action for revocation by surrendering his patent to the Comptroller, when the latter hears the parties and if he sees fit revokes the patent.

It is not an infringement of a British patent to use the invention for the purpose of navigating a foreign vessel in British waters, or to use it on such vessel for other purpose than the manufacture of anything to be sold in or exported from the United Kingdom or the Isle of Man, and provided the vessel be owned and registered in a foreign country having a similar law as regards British shipping.

Where a patent has been revoked on the ground of fraud, the Comptroller may, on the application of the true inventor, grant to him a patent in lieu of and bearing the same date as the patent so revoked, the patent so granted ceasing on the expiration of the term for which the revoked patent was granted.

\section{INFRINGEMENTS OF PATENTS.}

In case of infringement, before taking any action, the patentee should inquire thoroughly into the validity of the patent, and ascertain to the best of his ability whether the act complained of be really an infringement of it. The advice of a good Patent Agent on these points is of the highest importance.

Most large patent agent firms work in close collaboration with solicitors and barristers specialising in patent litigation.

Should the patentee, after applying for an injunction, make affidavit that he verily believes that his patent is valid, and is being infringed in a certain factory, and can give reasonable grounds for his belief, the court can grant an order for a single inspection of the works, but not, as a rule, of the books of the suspected infringer, to see whether the suspicion be correct. It will also compel the suspected party to answer under oath all reasonable interrogatories asked by the patentee as to the supposed infringement.

In the case of infringement of a patent dating subsequent to 1907, no damages can be recovered (but only an injunction and costs obtained) if in the opinion of the court the infringer had not reasonable means of becoming aware of the existence of the patent, and the marking of an article with the word "patent " is not deemed to constitute a notice of such existence unless the year and number of the patent be added, or the number 
only if granted subsequent to IgI6. There has been very little or no use made of this clause.

The infringement of a patent granted prior to I908, even though unintentional, being proved, the court can assess damages and decree costs, and further, will grant a perpetual injunction against the defendant continuing the infringement, on pain of fine and imprisonment. The decision can also be cited in applying for an interim injunction against other parties.

The court may, prior to the action, grant an interim injunction forbidding the infringer from continuing the use or manufacture of the patented invention, under pain of fine and imprisonment, until the trial be decided. This power, however, is at the discretion of the court, and is rarely made use of, except where the infringement is recent, the patent of long standing, and the application for the injunction has been made immediately after the infringement has been discovered.

Should the alleged infringer dispute the validity of the patent, or his infringement of it, the court, instead of granting the interim injunction, may order the infringer to keep careful accounts while the suit is pending of all articles manufactured, so that damages may more easily be assessed in case of conviction.

The patentee can be obliged to produce his letters patent in court, or lose his suit.

The court may order all matters of account to be decided by arbitration.

\section{LEGAL PROCEEDINGS.}

All appeals to the court from the Comptroller are heard before a special judge selected by the Lord Chancellor, and his decision is final, except in certain revocation cases.

The defendant can, if entitled to present a petition to the court for the revocation of the patent, apply for the revocation by way of counterclaim. By the Act of I9I9, if the court finds any one or more claims of the patent valid and infringed, it can grant relief in respect to any such claims which are infringed without regard to the invalidity of any other claim in the specification. But the court makes such terms as it thinks proper, and can take into consideration the conduct of the parties in inserting such claims or allowing them to remain.

This clause became law in I920, and takes away a very great hardship from the British patent law. It is, however, very desirable that a patentee should promptly disclaim any invalid claim or claims as soon as he finds it or them to be unsound.

In an action or proceeding for infringement or revocation of a patent, the court may, if it thinks fit, and must, on the request of either of the parties to the proceeding, call in the aid of an assessor specially qualified, and try and hear the case wholly 
or partially with his assistance ; the action is tried without a jury unless the court otherwise direct.

The Court of Appeal may, if it sees fit, and must on the request of all the parties to the action, call in the aid of a specially qualified assessor.

The remuneration, if any, paid to the assessor is determined by the court, and is paid by Government, and forms no part of the costs of the action.

In an action for infringement of a patent the owner of the patent must deliver with his statement of claim, or, by order of the court or the judge, at any subsequent time, particulars of the infringements complained of.

The person accused of infringing must deliver, with his statement of defence, particulars of any objection on which he relies in support of his case.

If the defendant disputes the validity of the patent, the particulars delivered by him must state on what grounds he disputes it, and if one of the grounds be want of novelty, must state the time and place of the previous publication or "user " alleged by him. He can also bring as a defence that the patent if more than four years old is worked mainly or wholly abroad.

At the hearing no evidence can, except by leave of the court or a judge, be admitted in proof of any alleged infringement or objection of which particulars were not so delivered.

Particulars delivered may from time to time be amended, by leave of the court or a judge, but in such case the payment of costs of the opposite party up to that date is frequently a condition of leave to amend.

In an action for infringement of a patent, the court or a judge may certify that the validity of any claim in the patent came in question; and if the court or a judge so certifies, then, in any subsequent action for infringement of that claim, the plaintiff in that action, on obtaining a final order or judgment in his favour, receives his full costs, charges, and expenses "as between solicitor and client," and so far as such claim is concerned, unless the court or judge trying the action certifies that he ought not to have the same.

On taxation of costs, regard will be had to the particulars delivered by the plaintiff and by the defendant; and they respectively cannot be allowed any costs in respect of any particular delivered by them unless the same be certified by the court or a judge to have been proven, or to have been reasonable and proper, without regard to the general costs of the case.

A patentee cannot get damages, but only an injunction and costs, where the defendant proves that his infringement was unwittingly made, not knowing of the patent, otherwise he can get an injunction and such damages as he can prove, but not an account of profits. 


\section{LICENSES AND ASSIGNIMENTS.}

A patentee can assign his patent in whole or in part, not only as regards its duration, but also its subject-matter and its territorial limits. But a patentee assigning any (say one-hundredth) part of a patent, unless there be a special agreement in writing, is giving the assignees in every respect an equal right with himself to work the invention and patent, but not to grant licenses, as they become simply co-owners of the patent. The owner or owners of a patent can grant licenses to use the patent on royalty, either exclusive or concurrent, and over the whole or only some part of the United Kingdom; and if the owners have unequal shares, the royalties must be divided in the ratio of such shares, unless there be a special arrangement to the contrary.

All licenses and assignments must be stamped, and must be registered in the Register of Patents in London; and copies of entries in this register, duly certified by the officials, are prima facie evidence in court of the facts therein set forth, only controvertible by direct proof of their incorrectness.

Copies of this register are open to the public in London, Edinburgh, and Dublin, on payment of a small fee, but the want of an index to the Dublin copy renders it of little use. Copies of any particular entry can also always be obtained from the department at the cost of making them.

In licensing an invention to a manufacturer, the patentee should take care to guard himself on the following points :(Ist) $\mathrm{He}$ should have quarterly statements of the number or quantity of the patented articles manufactured, and of their destinations, and should have the right of requiring the licensee to certify to the correctness of his returns under oath or by statutory declaration, or produce a certificate of a chartered accountant. (2nd) A right of inspection of the books and works of the licensee. (3rd) All articles manufactured undẹr the patent should be stamped with consecutive numbers, inventor's name and patent number and date, thus: "Jones, patent 247 of I908." To unlawfully affix these, subjects the offender to a fine of $£ 5$ for each offence. (4th) The patentee should either have a part of the royalties in advance, or a guarantee of a certain minimum royalty each quarter, so as to make it to the interest of the licensee not to let the patent lie idle.

On the other hand, the licensee should have the following protective covenants in his license :-(Ist) That all further improvements in the said invention made by the patentee, or his other licensees, shall be considered as included in his license (he also should agree to reciprocate in this matter). (2nd) That all disputes hereafter on the meaning or intention of the license shall be put to arbitration in a given way, and the award of the arbitrator be made a rule of court by either party. (3rd) 
That the licensee shall be allowed to sue in the name of the patentee in cases of infringement duly indemnifying him against costs. (4th) That the patentee shall maintain the patent by paying the stamp duties as they become due.

No contract in a deed of assignment or license made after 1907 shall be valid which contains a clause requiring the licensee to continue to pay royalties after the patent has expired, or prohibiting the purchaser or licensee from purchasing goods whether patented or not from other than the seller, licensor or his nominees ; unless it be proved that at the date of the deed the purchaser or licensee had the option of obtaining an assignment or license on reasonable terms without such restriction, or the contract contains a provision allowing the purchaser or licensee at three months' notice to commute such clause on terms fixed by an arbitrator appointed by the Board of Trade.

Such clauses in deeds or licenses made before Ig0 8 can be compulsorily cancelled by the purchaser or licensee at three months' notice on such terms as an arbitrator appointed by the Board of Trade may decide.

The insertion of such an illegal clause in a contract made after August 28, I907, is available as a defence to an action for infringement of the patent to which the contract relates brought while the contract is in force. In any action, application, or proceeding under the Act no person can be stopped from applying for or obtaining relief by reason of any admission or illegal contract as above. It is not an illegal contract for this purpose to bind the purchaser or licensee not to sell other goods than those of the patentee.

A person while a licensee of a patent cannot successfully plead the invalidity of that patent as a ground for refusing to pay royalty, except where there is an action for revocation pending.

If in a license it be stated that, unless a certain minimum royalty be paid yearly, the license can be cancelled by the patentee, and if for one or more years the patentee accepts a less royalty, he cannot afterwards cancel the license on the ground that the minimum royalty stipulated has not been paid, his having accepted the smaller royalty being held to be equivalent to cancelling this particular clause in the license, unless he made a special stipulation to the contrary before accepting the less royalty.

\section{HOW TO SELL A PATENT.}

Brokers of stocks and shares, houses and land, cotton, sugar, etc., abound, yet there is hardly a single firm in the world who are really brokers of patents. The inventor who has not sufficient leisure or capital to work his own invention has therefore usually to do his patent licensing or brokering himself. How 
should he go about it? In nine cases out of ten when asked this question, we reply: "Don't attempt to sell a patent, but try to license it to a good firm." We find this latter vastly easier than the effecting of a sale, and, as a rule, the royalties from a licensed patent, in one or at most two years, are more than the inventor would have got for the entire patent, if sold outright.

(I) Go to the greatest centre of the particular industry where that business is carried on with which the invention is most nearly connected. (2) If the invention be for a small object, get some specimens made and finished in the most pleasing style. (3) Issue a neatly printed prospectus. Many inventors start on their travels with a coarse, broken-down model, showing defects rather than virtues, or a dirty, ill-got-up drawing, whose very appearance is enough to set the capitalist at first sight against it ; whereas a pretty working model, showing the actual performance, and a nicely printed explanation, are prepossessing, and tend to carry conviction with them. It is often very desirable to have the invention well illustrated in the technical journals before offering it, but great care should be taken to secure its appearance in journals of high standing and large circulation, as these will not usually insert it after it has appeared in the smaller fry. (4) If the inventor wishes to still retain an interest in and assist in introducing his invention, a limited company, with the patentee as a director, is frequently his best resource. It is easier to sell a thousand shares in a patent at $£$ Io each than the whole for $£$ Io,000. The main business is to get a few good names as directors, and the rest is comparatively easy, if the invention be offered at a reasonable price, and has already come into successful use. Until this latter be made evident, it is useless to attempt to honestly float a company to purchase a patent. A small syndicate can frequently be formed to prove an invention first.

\section{CAUTION TO INVESTORS IN PATENTS.}

The ease, however, with which limited companies can be raised to purchase and work patents has given a handle to sundry unscrupulous adventurers to palm off on the public numerous patents, good, bad, and indifferent, at prices enormously exceeding their real value.

Nothing is easier than to get glowing testimonials for the most worthless invention, and capitalists, before investing in any patent, would do well to refer to a responsible and independent Patent Agent, to discover by an examination and search whether it be really valid. A minority only of the patents taken out under any circumstances are sound at law; and many even of these have nothing like their apparent value, from being hedged round by others with conflicting claims. 
Yet, almost smothered under this enormous load of worthless patents, there are numbers continually brought out by poor and obscure men, any of which, taken by a capitalist on the very liberal terms usually offered, would, properly worked, form a very handsome income. It is well worth the consideration of those who are continually investing in foreign loans, mines, railways, etc., whether it would not pay them better to take some poor but clever inventor by the hand, and, while thus encouraging trades and manufactures at home, employ their capital where it is constantly under their immediate inspection and control. Whether for safe and good paying investments, or for really brilliant speculations, there is probably no field left the capitalist, to be at all compared in richness with that of exploiting patented inventions. The capitalist should, however, take care to keep the control.

\section{HOW TO SAFELY INVEST IN PATENTS.}

Probably far more money is made by non-inventors investing in patents than by patentees. We have known many instances of men without any inventive faculty making fortunes in a very few years by investing in patents. This is not so often done by paying largely for a single promising patent and then working it, as by spreading their investments over several venturesfinding capital and business talent for clever but needy, or unbusiness-like, inventors, demonstrating the success of the inventions, and then negotiating their sale, receiving as a recompense a share of the net returns, varying from 25 to 75 per cent. One very successful plan is to find a patentee with a very valuable invention, whose entire resources are utilised in working the patent in the country of its birth. The capitalist offers to patent it abroad, before it has been " published," and negotiate the sale or license, giving the inventor from 25 to 50 per cent. of the net returns. As a rule he jumps at the offer.

We have very frequently known the foreign patents of inventions worth many thousands of pounds per annum in the country of their birth almost given away. It is this international-patent dealing that is, as a rule, the most profitable; yet it is a field almost untilled.

Again, for every invention really valuable in the country of its birth that is patented abroad, twenty are taken out in one country only, and for this reason: the inventors know the difficulty of their selling their foreign patents and attending to their home ones at the same time. But if they could hear through their Patent Agents of individuals or syndicates willing and able to take up or work patents in other countries, they would either patent abroad or sell their foreign rights at very reasonable rates, to the advantageous development of trade all over the world. 
Syndicates are mentioned above. For small capitalists, or men not having the leisure to work or negotiate the sale of patents, but with money to invest in them, the joining of a syndicate to engage in this traffic is frequently a very good thing. These syndicates, if properly managed, are very lucrative affairs. We do not mean to say they are usually successful in all their ventures - the cleverest of them fail in doing any good with some of their ventures-but if the risks are small, taken with due professional advice, and spread over a considerable number of patents (not all their eggs put in one basket), they are almost certain of a most lucrative business. Another way in which patent speculators have succeeded, especially in America, is to buy up or obtain a large interest in one or more patents, and, instead of selling them "out and out" in lump sums, they go round the country or engage smaller men to travel on commission, selling "shop-rights" and territorial rights-that is, the right of working the invention in a given manufactory only, or the exclusive rights to work the invention in a given town, city, county, state, or other district.

Illustrated abridgements made by the Government abstractors, of all British patents, are issued in any given class of invention, from in some instances the earliest times to present date.

Many of the most thriving and progressive manufacturing firms in this country and in the United States get these abridgements sent them regularly, with very great advantage to their business, and we have rarely known a client who has once adopted this ever give it up again-they find it too valuable.

It is a remarkable fact, too, that nearly all the great industrial houses in this country, on the Continent, and even in America, attribute their success to the taking up of some one or more patents; and probably not in one instance in three were any of the partners in the firm the original patentees, but were only the purchasers of the patents thus worked. They purchased or licensed them, often at a very small cost, from the original patentees.

\section{REGISTRATION OF DESIGNS.}

Any person a proprietor of an ornamental design unpublished in the United Kingdom can protect the same by registration for five years (renewable before the expiration of the term for a further period of five years, and renewable again if the Comptroller considers it worthy of such extension near the end of that period for a further term of five years). The definition of a design in law is " only the features of shape, configuration, pattern, or ornament applied to any article by any industrial process or means, whether manual, mechanical or chemical, separate 
or combined, which in the finished article appeal to and are judged solely by the eye, but does not include any mode or principle of construction, or anything which is in substance a mere mechanical device." Any design applicable to any article of manufacture or to any substance natural or artificial, or partly natural and partly artificial, whether it be formed by printing, painting, embroidery, weaving, sewing, modelling, casting, engraving or otherwise can be thus protected.

Artistic and architectural works of art, casts, models, and sculpture are still protected without registration under the Copyright Acts unless intended to be reproduced in more than fifty specimens, but a set of articles such as chessmen ordinarily on sale together are reckoned in this case as one article, and are registrable in one registration. The Comptroller is the sole judge as to whether any given articles constitute a set.

Printed paper hangings, carpets, floor cloths, oil cloths, unless manufactured or sold in lengths or pieces, textile piece goods and lace not made by hand, can now no longer be registered under the Copyright Act, but must be registered at the Patent Office. The Comptroller has the power of refusing to register a design on the ground that it is not new, or not a registrable design, subject to appeal to the courts, and where a principle of mechanics is sought to be protected under the design registration, he is very apt to refuse registration or require that such principle shall be disclaimed. With every registration a special number is given to the proprietor and he is bound to mark all articles made in accordance with the registered design with the word " Registered," "Regd." or " Rd.," as he prefers, and (except in goods in classes 9, I3, I4 and I5), with the said number, or if the article forbids such marking, then the package in which it is must be marked, but marking can be dispensed with in the case of printed cotton piece goods except handkerchiefs. If the owner of the design does not take all proper steps to insure such marking or prove that the infringer knew of the registration, when he pirated the design, he cannot obtain damages in case of infringement. The Board of Trade can in certain trades where such markings are undesirable modify or dispense with these marking requirements. Any person marking an article as registered after the registration has expired is liable to a fine not exceeding $£ 5$.

All trade marks allowed by the Comptroller are pictorially advertised in the Trade Marks Journal, a weekly paper. This forms practically a copy of the register, except that the cotton marks registered in Manchester are omitted.

During the first two years of copyright, or such further time as may be prescribed, the registered design is not open to inspection of the public-except by special order in each specific case from the proprietors of the design, or from the Comptroller, 
or from a Court of Law ; but after the expiration of said period it can be inspected at the Patent Office, and copies made for a prescribed fee. If, however, any one wishes to know whether a particular design has been registered under a given number for a given class of goods, or by a given person on a given date, he can obtain this information for a prescribed fee. If a registered design be applied to manufacture of any article in any foreign country, and is not so applied by a manufacturer in the United Kingdom to such an extent as is reasonable in the circumstances of the case, any person interested may apply to the Comptroller for the cancelling of the registration of the design, but the Comptroller may adjourn the application, if he thinks fit, to such time as he may deem sufficient for the owner of the design to start the manufacture in the United Kingdom, or in lieu of cancelling the design he may order the grant of a compulsory license on such terms as he considers just. If the design had been already published in the United Kingdom prior to the date of registration, the Comptroller has also the power of cancelling the registration.

A Register of Proprietors of Designs is kept at the Patent Office, and all assignments, licenses or changes of address can be recorded therein for a prescribed fee. Such registration is primâ facie evidence of ownership, and an unregistered proprietor cannot bring an action for infringement until he is registered as the owner. The rule applicable to patents in the case of international exhibitions, set forth on page 25 , is applicable to designs.

A design already published cannot be validly registered, with these exceptions :-if the publication be surreptitious by a third party without the knowledge or consent of the author and owner of the design, or it be merely the acceptance of the first and confidential order in the case of textile designs, or the design has been registered in another class by the author and only applied to goods in that class; but in this latter case the registration is liable to be granted for only so long as the original registration can be maintained.

Any person who during the continuance of copyright in a design-without the consent of the proprietor-applies the design, or any fraudulent or obvious imitation thereof, to any article or substance in the class in which the design is registered, or publishes or exposes for sale, or sells such article or substance, with such design, knowing that the same has been applied without the consent of the registered proprietor, is liable to forfeit a sum not exceeding $£ 50$ for one offence, or $£$ Ioo, but not more, for two or more offences, to the registered proprietor of the design, who may recover such sum, as a simple contract debt, by action in any court of competent jurisdiction. Or in lieu of this, the proprietor of the design can enter an action for damages, and obtain an injunction as in the case of patent infringement. 
Goods are divided into fifteen classes, and a separate registration is required for each class in which it is desired to secure the design. In case of doubt as to which class a design ought to be registered in, the Comptroller may decide the question.

Any person making groundless threats of legal proceedings for infringement of copyright of design, and not promptly bringing an action if defied, can be prosecuted for damages, as in the case of patents.

The classes are as follows:-

Class I.-Articles composed wholly of metal or in which metal predominates, and jewellery.

Class 2.-Books and bookbinding of all materials.

Class 3.-Articles composed wholly of wood, bone, ivory, papier-mâché, or other solid substances not included in other classes, or of materials in which such substances predominate.

Class 4.-Articles composed wholly of glass, earthenware or porcelain, clay (burnt or baked), or cement, or in which such materials predominate.

Class 5.-Articles composed wholly of paper, cardboard, millboard or strawboard (except articles included in class 2, and paper-hangings), or in which such materials predominate.

Class 6. - Articles composed wholly of leather or in which leather predominates, not included in other classes.

Class 7.-Paper-hangings.

Class 8.-Carpets, rugs and floor coverings in all materials.

Class 9.-Lace.

Class ro.-Boots and shoes.

Class II.-Millinery and wearing apparel (except boots and shoes).

Class 12.-Goods not included in other classes.

Class 13.-Printed or woven designs on textile piece goods (other than checks or stripes).

Class I4.-Printed or woven designs on handkerchiefs and shawls (other than checks or stripes.)

Class 15.-Printed or woven designs on textile piece goods or on handkerchiefs or shawls being checks or stripes.

Application may be made to register a design applied to a number or "set" of articles of the same general character. The Comptroller decides as to what usually constitutes a "set."

A design registration can be revoked by the Comptroller on the suit of any interested party, on the grounds that the design was published before the date of registration, or that it is applied by manufacture in any foreign country and is not so applied in the United Kingdom to a reasonable extent; and such ground of defence is available in all actions for infringement. If applied to on this latter ground, in case of hardship, the Comptroller can give the owner of the design longer time to get well to work 
- or grant a compulsory license on such terms as he may consider just.

The law as regards Government being allowed to use the design is similar to that in the case of patents.

In a number of countries, adherents to the International Union or Convention for Industrial Property (see page 22), registration of design application gives a period of four months' priority protection in the other countries.

\section{PATENT MEDICINES.}

It is customary to style all proprietary medicines " patent medicines," though they are rarely the subject of a patent. It is indeed hardly ever desirable to patent a medicine, as a mere prescription cannot validly be patented, but patenting it simply explains its manufacture for the benefit of imitators. The best mode of protecting a medicine is to get a distinctive name, and register that name as a trade mark.

From $I 920$ it is illegal to include claims in any patent for a substance intended as a medicine, except when prepared or produced by special methods or processes claimed. Further, in the case of any patent on an invention capable of being used for the purpose of medicine, the Comptroller may grant licenses to any person restricted to the use of the process for the manufacture of medicine only, and at royalties within his discretion.

Proprietary medicines must bear a Government medicine stamp on every package or bottle, the price of which stamp is $3 d$. for the selling value of $1 s$., $6 d$. for $2 s .6 d$., Is. for $4 s$. , and more for higher prices, while the seller must be the holder of a license. This license costs $5 s$. a year. The Government stamp does not convey a right in the nature of a patent, but is a duty imposed by law on these proprietary medicines or specifics.

The stamps for denoting these duties can be obtained on application, but when the proprietor of the medicine desires to vend it under Stamp Duty Labels specially appropriated to himself and having his name or other particulars thereupon, it is necessary to have a plate specially engraved for printing such stamps. The cost of engraving an appropriated medicine stamp plate is about $f 8$. Such appropriated labels are only supplied to the person for whose use and at whose cost the plate from which they are printed was prepared, or to his authorised agent. The penalty for infringement is $£$ Io for every case.

\section{TRADE MARKS.}

There are few things of more value to the merchant or manufacturer than the exclusive right to the use of a trade mark or 
trade name, by means of which his goods are at once recognised, and which can be secured against all comers. The name of a firm can be imitated so nearly as to be calculated to deceiveor even adopted altogether by others of the same surname, and the firm has usually no redress-but the fraudulent imitating of a validly registered trade mark is a criminal as well as a civil offence. The necessity for valid registration, however, is not sufficiently realised by many until they discover their marks pirated by unscrupulous rivals. Then when they come to register them, they too often find that their marks are not registrable, or perhaps have been already registered by their rivals.

Registration at Stationer's Hall, now abolished, is of no value as a protection for a trade mark, except perhaps as evidence of its having been in use at the date of such registration.

All traders who use trade marks or names to distinguish their goods should be careful only to adopt such as are registrable under the latest Acts of Parliament, as construed by the courts, and should have such marks registered both at home and, if they have, or expect to have foreign trade, abroad, as soon as adopted, and before any great amount of expense has been incurred in advertising them or bringing them before the public. By taking this course a large amount of annoyance and expense will often be saved, and the proprietor will have the satisfaction of knowing that he has an indefeasible right to his distinguishing mark.

No person has any exclusive right to the use of a trade mark (nor can he take any steps under the Trade Marks Act to prevent infringement or piracy) until the trade mark is registered, or unless, the mark being unregistrable, he succeeds in establishing a proprietorship by long and large usage.

\section{WHAT CAN BE REGISTERED.}

The Trade Marks Act I9I9, which came into operation on April I, I920, makes changes in the law which are of great importance to traders. This new law divides the register of trade marks into two parts-Part A and Part B.

Under Part A, a registrable trade mark must contain or consist of at least one of the following essential particulars:-

I. The name of the applicant represented in a special or particular manner or the signature of the applicant or some predecessor in his business.

2. An invented word or words, or a word or words having no direct reference to the character or quality of the goods, and not being, according to its ordinary signification, a gecgraphical name or a surname.

3. Any other distinctive mark, that is, a mark to distinguish the goods of the proprietor of the trade mark from those of other 
persons and not objectionable otherwise. Word marks other than those of clauses I and 2 cannot be deemed distinctive except by order of the registrar or a court, who can, if the mark be in actual use, take into consideration the extent to which such use has made it distinctive, that is, as distinguishing the proprietor's goods from those of other persons.

4. Any special or distinctive word or words, letter or letters, numeral or numerals, used as a trade mark by the applicant or his predecessors with but slight alteration continuously since before August I3, I875.

Part B of the register is to comprise all trade marks which, though not registrable in Part $\mathrm{A}$, are capable of distinguishing a trader's goods, and have been in bonâ fide use for not less than two years.

In selecting a trade mark, care should be taken to avoid anything that would be indicative of the quality or the character of the goods, and yet, if possible, to get one that would give a good impression every way. Thus, "Sunlight" was a remarkably good trade mark for soap, as it indicated light, sweetness and purity. Similarly, "Bovril" was a very good word; as although Bov meant an ox, "ril " meant nothing, but "vril " was well known through one of Bulwer Lytton's novels which indicated tremendous strength, and, therefore, Bovril indicated great strength obtained from an $\mathrm{Ox}$, while at the same time it was a purely invented word, and therefore registrable.

Another point in selecting a trade mark is to make it as short as possible. Thus Oxo, Kodak, etc., are words which are shown to have no other meaning, and consequently they are very difficult to pirate.

\section{PART “A" MARKS.}

The words "invented word" are now understood to mean any word which is not actually used in any well-known language, unless it be merely bad spelling; or an unregistrable word with a simple suffix or affix. Thus neither sope or soape could be registered for soap.

The clause against the use of a geographical name is also much more liberally interpreted than formerly. Thus "Magnolia" was allowed to be registered as part of a trade mark, although a dozen towns or villages are found in the United States named Magnolia, as the word Magnolia to the public at large is indicative of a tree, and not of those towns. Similarly with regard to surnames; at one time a single entry in the London Directory of a surname, such, for instance, as Crocodile, would entirely preclude the registration of said name as a trade mark. Now, however, a name like Crocodile or Monkey could be registered 
as a trade mark, even if there be a Mr. Monkey or a Mr. Crocodile in the London Directory or otherwise, provided there be a clause stating that this registration shall not prevent any person of the name of Crocodile or Monkey, as the case may be, from using his own name or any foreign translation of such name.

Latitude, too, is given in bonâ fide cases to permit identical trade marks to be registered to more than one applicant where the areas of trade do not clash, and are not likely to clash, in this case restrictions being placed on the register as regards geographical area, mode of using, or otherwise, so as to prevent confusion and deception of the public.

The colour of a trade mark can be claimed as a distinctive element ; if no colour be claimed, the mark is held to be registered for all colours.

The following are not registerable even as parts of trade marks :-

Representations of His Majesty the King, or of any member of the Royal Family.

The Royal Arms, or arms so nearly resembling them as to be calculated to deceive.

Representations of the Royal Crown, or use of words " Royal," " King's," "Queen's," "Imperial," "Crown," the Admiralty seal, flag, or anchor.

The device of a cross in red, the badge of the Royal Air Force, the broad arrow.

The National Arms or Flags of Great Britain.

The words " Registered," "Registered Design," " Copyright," "Entered at Stationers' Hall," "To Counterfeit this is Forgery."

If, moreover, a trade mark nearly resemble another already registered, registration may be refused; nor can anything " calculated to deceive," or any " scandalous design," be registered.

\section{PART “B” MARKS.}

Registrations in Part B are intended to afford the status of registration to marks which have been in use for two years, and so remove the long-felt grievance of marks which, because hitherto unregistrable in Great Britain, were also deprived of registration in many foreign countries, where proof of the home registration is required of every British applicant. Every application in Part B must be accompanied by a statutory declaration verifying the two years' usage, and giving full details.

\section{APPLICATION FOR REGISTRATION.}

Any person, firm, company, corporation, or association, British 
and alien, can apply for and obtain registration of his or their trade marks.

All applications in Part A are first formally examined, and if they are found to come within the definition of a trade mark, and do not conflict with others already on the register, they are passed by the Trade Marks Office, usually within four to eight weeks after application. If the Registrar refuses, an appeal can be had to the Board of Trade. They are then advertised, and within one month of the appearance of such advertisement any interested or aggrieved person who may consider himself to have a prior claim to the mark may enter opposition to the registration. Should no opposition be entered during the aforesaid period, or such further time as may be allowed in certain cases, and should no exception be taken by Government officials, the mark is formally registered.

If an application be opposed, or two or more persons apply for registration of the same trade mark contemporaneously, the case will be heard by the Registrar of Trade Marks, who will decide as to their respective rights to the said trade mark.

The Registrar of Trade Marks can decree costs to the winning party, to be paid by the loser.

The decision of the Registrar is subject to appeal to the court.

As regards applications in Part B, the authorities are given the option of bringing them into comparison with previous registrations, or to refrain from doing so, but in any case they are required to apply the test of two years' user. If the authorities decide not to search, marks registered under Part B will probably be reduced to the status of a mere record of claim, such as used to be effected by entry at Stationer's Hall.

If applications in Parts A or B be refused, an appeal can be had to the Registrar or to the Board of Trade, who can at any time allow the applicant whose application is being adjudicated on to amend such application on terms, and may require the applicant to disclaim parts of his mark common to the trade.

Opponents outside the United Kingdom may be required to give security for costs.

Where any association undertakes the examination of any goods in respect of origin, material, mode of manufacture, quality, accuracy, or other characteristic, and certifies the result of such examination by mark used upon or in connection with such goods, the Board of Trade may permit such association to register such mark as a trade mark in respect of such goods. This enables such marks as the Hall marks on silver, or the Kew standardisation marks on watches, the certifying marks of the Testing House, and other like marks to be registered. This created a class of trade marks, which, prior to I905, could not have been protected by registration.

Where two or more parties claim to be the proprietors of the 
same mark, and are not in partnership, the Registrar may refuse to register it till their rights have been determined by a court ; but the court can grant it to both parties.

If the registration be not completed within twelve months from the date of application (through the fault of the applicant) it is held to be abandoned. When registered it is dated as of the day of application.

\section{EFFECT OF REGISTRATION.}

The registration of a trade mark is prima facie evidence of the legal right to such trade mark being vested in the person so first registering.

The registration of a trade mark in Part $\mathrm{A}$ is, after seven years, conclusive evidence of the right to the exclusive use of the same; that is to say, the validity of the original registration cannot be challenged after seven years on the ground of prior right by third parties, or except for non-user or fraud in using it, or that the mark has ceased to be a distinguishing mark. I

Registration in Part B is not so conclusive. In any action for infringement no relief will be granted to the owner of a mark in Part $\mathrm{B}$, if the defendant establishes to the satisfaction of the court that the user of which the plaintiff complains is not calculated to deceive.

Abandoning the use of a trade mark for a term of years vitiates the rights obtained by registration. If, however, its use be recommenced, the old registration is sufficient against all persons, except those claiming to have used the mark before the recommencement of using.

Registration lasts for fourteen years, and can be renewed again and again for further periods of fourteen years. If the renewal fee be not paid before the expiration of the fourteen years, the owner has the option of paying it, together with a prolongation fee, any time during the ensuing one month or with an additional fee within the next three months; in default of which the trade mark is removed from the register, but can be applied for afresh as if never before registered.

A trade mark having been removed from the register in this way cannot be registered for another proprietor until after one year has elapsed, unless it be shown that the non-payment of the fee arose from the death or bankruptcy of the proprietor, or from his having ceased to carry on business for more than two years, and that no person claiming under that proprietor is using the trade mark.

No proceedings relating to infringement, or to recover damages in respect of an unregistered mark, can be instituted unless the mark was in use before August I3, 1875, and has been refused registration under the new Act. 
A trade mark can only be assigned with the goodwill of the business in the goods to which it relates, and in cases where a trade mark owner ceases to carry on business and the goodwill is divided, the Registrar may, subject to the provisions hereafter mentioned in the case of associated marks, apportion the marks to the claimants as he sees fit, subject to appeal to the Board of Trade.

It is obligatory for a subsequent proprietor of a trade mark to enter his title on the register. If he fails to do so within six months of the date of acquisition of the proprietorship, he is fined ten pounds for the first mark, and half a crown for each subsequent mark.

An assignment, unless there be a special clause to the contrary, conveys no right to the mark in the Colonies or foreign countries.

When an applicant registers several marks closely resembling each other they will only be registered as " associated " marks, and cannot be assigned separately.

Abandoning the use of a trade mark for a term of years vitiates the rights obtained by registration. If, however, its use be recommenced, the old registration is sufficient against all persons, except those claiming to have used the mark before the recommencement of using.

\section{AMENDMENT OF REGISTER.}

Any interested party can apply for any entry in the register to be corrected or rectified, or for an address to be altered, for his own registration of a trade mark to be cancelled in whole or in part, such as eliminating therefrom a claim for the use of the trade mark for certain goods, or for a slight alteration in the trade mark as registered, not affecting its substantial identity, and from the decision of the Registrar appeal can be had to the Board of Trade. If the amendment be allowed it is advertised in the Trade Marks Journal, so that any interested party can oppose it.

Any interested party can apply to the courts to have a mark removed from the register in whole or for certain goods if the mark be not in use at all or for such goods. In certain cases the Registrar has power to expunge a mark from the register.

\section{SEARCHES.}

No trade mark in Part A having strong resemblance to one already on the register in respect of similar goods is officially accepted for registration. 


\section{CLASSES.}

A trade mark must be registered for particular goods or classes of goods. Registration in each class is treated as registration of a separate mark. There are fifty classes of goods.

According to the classification of the Trade Marks Office, they are as follows:-

I. Chemical substances used in manufactures, photography or philosophical research and anti-corrosives, such as acids, alkalies, paints, natural dyes, varnishes, photo films.

2. Chemical substances used for agricultural, horticultural, veterinary and sanitary purposes, such as manures, sheepwashes, deodorizers, chloride of lime for disinfecting.

3. Chemical substances used in medicine or pharmacy, such as tinctures, patent medicines, cod-liver oil, plasters.

4. Raw and partly prepared vegetable, animal, and mineral substances used in manufactures not included in other classes, such as resins; oil for chemical purposes, such as creosote oil ; dyes other than mineral, tanning materials, wool, silk, bristles, hair, feathers, cork, linseed, coal, coke, bone, sponge, electric carbons.

5. Unwrought and partly wrought metals used in manufacture, rough pig or ingot, hoops, wire, bars, rails, bolts, sheets or plates of iron, steel, lead, copper, zinc, tin, bismuth, antimony ; also precious metals in ingots.

6. Machinery (except agricultural machinery), such as steamengines, boilers, machine tools, sewing machines, dynamos and motors.

7. Agricultural machinery, such as ploughs, threshing machines, churns, cider presses, chaff-cutters.

8. Philosophical instruments and apparatus for useful purposes, such as gauges, school desks, ships' logs, cameras, telegraph cables, gramophones, moving-picture apparatus, commutators, volt meters.

9. Musical instruments.

Io. Clocks, watches, and horological instruments generally.

II. Surgical apparatus, instruments, and contrivances not medicated, such as bandages, friction gloves, lancets.

I2. Cutlery, and edged tools, such as knives, shears, files, saws.

I3. Metal goods not included in other classes, such as anvils, keys, needles, shovels, corkscrews, electric-light lamps, wire ropes.

I4. Precious and rare metals and jewellery, including aluminium, nickel, Britannia metal, plated goods, pencil cases, and clock cases of such metals.

I5. Glass of all kinds.

I6. Porcelain, earthenware, bricks, tiles, insulators.

I7. Manufactures from mineral and other substances used for 
building, such as cement, plaster, imitation marble, and asphalt.

I8. Engineering, architectural and building contrivances and apparatus, such as diving, warming, filtering, lighting, or draining contrivances, electric and pneumatic bells, electric lighting and heating apparatus.

I9. Arms and military stores not explosives, such as guns, swords, shot and other projectiles, camp equipage and equipments.

20. Explosive substances, such as powder, dynamite, fog signals, caps, fireworks, cartridges.

2I. Naval architectural contrivances and appliances, such as boats, anchors, chain cables, rigging.

22. Carriages, such as railway waggons, carts, coaches, velocipedes, bicycles, bath chairs, perambulators, aeroplanes, motor cars.

23. Cotton yarn, thread, and sewing cotton.

24. Cotton piece goods of all kinds, such as cotton shirtings and longcloths.

25. Cotton goods not included in Classes 23,24 , or 38 , such as handkerchiefs, cotton smallwares, coverlets, d'oyleys, napkins, shawls, sheets, tablecloths, towels, and dusters.

26. Linen and hemp yarn and thread.

27. Linen and hemp piece goods.

28. Linen and hemp goods not included in Classes 26, 27, and 50 , such as linen cords, braids, trimmings, lace, and other linen or hemp smallwares.

29. Jute yarns and tissues and other articles made of jute not included in Class 50.

3o. Silk, spun, thrown, or sewing.

3I. Silk piece goods.

32. Other silk goods not included in Classes 30 and $3 I$.

33. Yarns of wool, worsted, or hair.

34. Cloths and stuffs of wool, worsted, or hair.

35. Woollen and worsted hair stuffs, not included in Classes 33 and 34 .

36. Carpets, floor-cloths, and oilcloth, matting, rugs, druggets, etc.

37. Leather skins (unwrought and wrought), and articles made of leather not included in other classes, such as harness, whips, portmanteaus, furs.

38. Articles of clothing of all kinds.

39. Paper (except paper-hangings), stationery, printing, bookbinding, ink, playing cards, books, copying presses, blotting cases, sealing wax, envelopes.

40. Indiarubber and gutta-percha goods not included in other classes.

4I. Furniture and upholstery, paper-hangings, japanned goods, mirrors, mattresses, papier-mâché. 
42. All substances used as food, or ingredients in food, such as provisions, farm produce, tinned meats, fish, fruit, etc. ; cereals, pulses, salt, olive oil, tea, coffee, cocoa, confectionery, hops, malt, oil-cakes, pickles, vinegar, beer clarifiers, etc.

43. Fermented and spirituous liquors, such as beer, cider, wine, whisky, liqueurs.

44. Mineral and aerated waters, natural or artificial, including ginger beer.

45. Tobacco of all kinds, manufactured or otherwise.

46. Seeds for agriculture or horticulture.

47. Candles, illuminating, heating, or lubricating oils, matches, washing blue, common soap, detergents, starch, benzine, washing powders, chloride of lime, and other chemicals for bleaching.

48. Perfumery, including scented soap, dental powders or preparations, hair washes, or pomatums.

49. Toys, games, archery, fishing tackle, billiard tables, skates.

50. Miscellaneous, including bags, sacks, tents, tarpaulins, bone, ivory, and wood manufactures not otherwise classified, brushes and combs (except artists' brushes), straw and glass goods not otherwise classified, also cordage, rope, and twine, animal and vegetable manufactured goods not otherwise classified, coopers' goods, artificial fuel, drinking flasks (not precious metal), tobacco pipes, furniture cream, plate powder, diamond cement, polishing paste, umbrellas, grindstones, oil-stones, hones, emery, and in general, miscellaneous goods not otherwise classified in the previous classification.

The owner of a trade mark licensing, or even tacitly permitting, another or rival firm or individual to use his trade mark forfeits his exclusive right to such trade mark. This does not apply, however, if the goods marked are the trade mark owner's own goods put up or bottled by the other.

No word which is the only practicable name or description of any single chemical element or single chemical compound as distinguished from a mixture, can be registered as a trade mark.

Where a new article, the subject of a patent, has become known by a distinctive name, any person is entitled, after the expiration of the patent, to make or sell it under such name, and the patentee cannot prolong his monopoly by registering the same name as a trade mark.

In any legal proceeding referring to the validity of a registered trade mark, which is decided in favour of the proprietor of such trade mark, the court may certify the same, and if it so certifies, then in any subsequent legal proceeding, the proprietor of such trade mark, on obtaining an order or judgment for infringement, shall have full costs, charges, and expenses, as between solicitor and client, unless the court certifies that he ought not to have the same. 


\section{PROCEDURE IN REGISTERING A TRADE MARK.}

The patent and trade mark agent requires seven copies on paper of each trade mark for each class of goods required, and, if you have it, a stereo. block for each class, with the following particulars :-

Ist-At what date the trade mark was first used.

2nd-State clearly all the kinds of goods in connection with which the trade mark is used or intended to be used, reference being made to the classes. (See pages 47, etc.)

3 rd-If you have more than one trade mark, send particulars of all the trade marks at the same time, as several can be registered together more cheaply than separately.

4 th-A signed letter of authorisation on foolscap paper in the following words :- "Messrs.

, are hereby appointed agents of the undersigned in all matters relating to the application for the registration of trade marks. Communications to be sent to their office." Name in full, address in full, and business. If the applicant be a limited company it must be signed (Name of Company), per —Secretary.

\section{PENALTIES.}

Any person representing that a mark is registered when it is not, is liable on summary conviction to a fine of $£ 5$ for each offence.

Any person who forges or counterfeits any registered trade mark is guilty of an offence against the Merchandise Marks Act. Any person who sells, exposes for sale, or has in his possession for sale, any article with a forged or counterfeit registered trade mark, which he knows to be wrongly or fraudulently applied, is guilty of an offence against said Act.

Any person selling, or exposing for sale, or having in his possession for sale, any article with a forged or counterfeit registered trade mark, even when not knowing it to be counterfeit, is guilty of an offence under this Act, unless he can prove to the satisfaction of the court that hears the case that he had taken all reasonable precautions against committing an offence; or that he had no reason to suspect the genuineness of the trade mark; or that on demand he gave all the information in his power with respect to the persons from whom he obtained such goods; or otherwise that he had acted innocently.

Any person who applies to any goods a false trade description as to the number, quantity, measure, gauge, or weight, the place or country of origin, the mode of manufacturing, the material of which they are composed, or falsely denominates them the subject of an existing patent, privilege, or copyright, is guilty of an offence against this Act. 
Any person who falsely represents that any goods are made by a person holding a Royal Warrant, or for the service of His Majesty or any of the Royal Family, or a Government Department, shall be liable on summary conviction to a penalty not exceeding $£ 20$.

Any goods of foreign manufacture or origin purporting to be of English make, or so marked or described that the possession of them would render the holder liable under this Act, are prohibited importation into the United Kingdom, and may be seized and retained under the regulations for the Commissioners of Customs.

In cases where the trade description implies that the goods are the produce of a given place or country and the goods are not actually made or produced in that place or country, there must be added to the trade description immediately before or after the name of that place or country if given, or after such implication in an equally conspicuous manner with that name or implication, the name of the place or country in which the goods were actually made or produced, with a statement that they were made or produced there.

Any person within the United Kingdom aiding or abetting in the commission, without the kingdom, of an act which, if committed within the kingdom, would be an offence, is guilty of an offence against the Act as a principle, and may be prosecuted at the place at which he resides.

Every person guilty of an offence against the Act is liable-

I. On conviction on indictment to imprisonment, with or without hard labour, for a term not exceeding two years, or to a fine, or to both imprisonment and fine.

2. On summary conviction to imprisonment, with or without hard labour, for a term not exceeding four months, or to a fine not exceeding $£ 20$; and in the case of a second or subsequent conviction, with or without hard labour, for a term not exceeding six months, and to a fine not exceeding $£ 50$.

3. In any case he forfeits to His Majesty every chattel, article, instrument, or thing falsely marked, or by means of, or in relation to which the offence has been committed.

\section{FOREIGN REGISTRATION.}

It is also of the utmost importance to those merchants and manufacturers whose goods are exported to have their trade marks registered in every country or colony in the markets of which the goods are sold. Registration at home gives no protection whatever outside the United Kingdom, and it is well known that native manufacturers, and those competing from other foreign countries, pirate and counterfeit British traders' 
marks when such are not registered in the country to which the goods are going. Instances, too, frequently occur of the consignee of a British trader registering the mark as his own, for the purpose of securing a monopoly to himself of all goods so marked.

We therefore strongly advise all owners of trade marks to have them registered in any and every country in which their goods find a market.

The following is a list of the foreign countries and British Colonies in which the rights to trade marks can be secured by registration :-

* Antigua.

Argentine Confed.

Australia.

Austria.

Bahamas.

Barbadoes.

Basutoland.

Bechuanaland.

Belgium.

Bermuda.

Bolivia.

Brazil.

British Central Africa.

British Guiana.

British Honduras.

British North Borneo.

Bulgaria.

Canada.

Ceylon.

Channel Islands.

Chili.

*China.

Colombia (U.S. of).

Congo Free State.

Costa Rica.

Cuba.

Cyprus.

Czecho-Slovakia.

Deccan.

Denmark.

* Dominican Republic.

Dutch East Indies.

Dutch West Indies.

East Africa.

Ecuador.

Egypt.

Falkland Islands.

Fiji.

Finland.

France and Colonies.

Gambia.

Germany.
Gold Coast.

Greece.

* Grenada.

Guatemala.

*Hayti.

Holland.

Honduras (Republic).

Hong Kong.

Hungary.

Iceland.

India.

Italy.

Jamaica.

Japan.

Jodhpur.

Jugo-Slavia.

Kedar.

Kelatan.

Leeward Isl.

Liberia.

Luxembourg.

Malay States.

Malta and Gozo.

Mauritius.

Mexico.

Morocco (French).

Mysore.

Newfoundland.

New Zealand.

Nicaragua.

Nigeria.

Norway.

Nyassaland.

Oman.

Palestine.

Panama.

Paraguay.

Peru.

Philippine Islands.

Poland.

Porto Rico.

Portugal.

- No Trade Mark Registration Law exists in this country, but we advise the advertisement of the trade mark as a warning to the public and as a means of proving ownership in the person
w ho advertises in case of suit. 
Portuguese Colonies.

Rhodesia.

Roumania.

Russia.

San Domingo.

San Salvador.

Siam.

Sierra Leone.

* Soudan.

South Africa.

Spain.

St. Helena.
St. Lucia.

* Straits Settlements and Labuan.

Surinam.

Sweden.

Switzerland.

Trinidad.

Tunis.

Turkey.

United States.

Uruguay.

Venezuela.

Zanzibar.

The first application for a trade mark in one of the countries of the International Convention or Union for Industrial Property gives a priority period of four months in the other countries (see page 22).

\section{COPYRIGHT.}

By the Act of I9II, which came into force July I, I9I2, there is no registration of copyright, but the author of any literary, musical, or artistic matter is entitled, without registration, to the copyright of his work for his lifetime, and fifty years after, provided the author be a British subject, resident in the realm at the time of first publication, or in the case of unpublished matter, if he be a British subject. The Government has a right to extend the whole or part of this privilege to the citizens or subjects of all countries having international agreements for the purpose with Great Britain, and also to the self-governing colonies of Canada, Australia, New Zealand, Newfoundland, and South Africa. All other British Colonies are for the purposes of this Act considered a part of Great Britain. To secure the copyright five special public libraries have to be supplied with a copy each, and certain other libraries have the right to a gratis copy from the author, if they write for it.

Sculptures are protected for fourteen years, with a further term of fourteen years if the original sculptor be then living, by the simple act of placing them in a public position, and marking them with the name of the sculptor in each case before being exhibited or sold.

\section{Colonial Copyright.}

A British copyright extends to the colonies, except Canada, and vice versâ ; but the colonies can allow the importation of foreign reprints into their territories on paying a small fee for each reprint to the British author. The Dominion of Canada

* No Trade Mark Registration Law exists in this country, but we advise the advertisement of the trade mark as a warning to the public and as a mcans of proving ownersbip in the person who advertises in case of suit. 
did this till December I894, but then passed an Act stopping the collection of said fees, and has since passed a copyright law of its own.

\section{INTERNATIONAL COPYRIGHT.}

Belgium, the British Empire (except Canada), France, Germany, Hayti, Italy, Luxembourg, Monaco, Norway, Spain, Switzerland, Tunis, and Japan, form the Copyright Union, and copyright in any one country of the union gives copyright in the others. The United States and England have a copyright treaty, and simultaneous publication in the two countries (the printing being done in each case from type set in that country) and registering in accordance with the law protects the copyright in both countries. France, Belgium, Denmark, Switzerland, Italy, and Germany also have a similar understanding with the United States.

\section{FOREIGN PATENTS.}

As inventions, designs and trade marks, valuable in this country are usually equally so in foreign states and colonies, we append, as a second part of this work, a brief epitome of the law of each country-longer for the more important ones than for those of less importance. In this we have endeavoured to give, in a concise form, those parts of the respective laws most valuable to a patentee. 


\section{FOREIGN PATENT LAWS}

\section{AFRICA.}

NEARLy all the British colonies, no matter how small, have a separate patent law which may be looked for under the name of the respective colonies. Some of the French, Italian, Spanish, and Portuguese colonies are covered by patents of their mother-countries. Tripoli is covered by the Italian patent, Madagascar and Algeria by the French, while Congo Free State, Egypt, but not Soudan (British and Egyptian), South Africa, Sierra Leone, Nigeria, Rhodesia, Zanzibar, East African Protectorate, Gambia, Gold Coast, Liberia, Morocco (French zone), Tunis, Uganda, and Basutoland have independent patent laws and grant patents. These will be found under the headings of the respective states.

\section{ALGERIA.}

This country is covered by the French patent.

\section{AMERICA (NORTH).}

See Canada, Mexico, Newfoundland, and United States.

\section{AMERICA (CENTRAL).}

See British Honduras, Costa Rica, Guatemala, Nicaragua, Salvador, Panama, and the various West Indian Islands.

\section{AMERICA (SOUTH).}

See Argentina, Bolivia, Brazil, Chili, Colombia, Ecuador, Guiana, Paraguay, Peru, Uruguay, Venezuela.

\section{ARGENTINA.}

(Law of II October, I864.)

Population, 8,300,000.

Anything that would be patentable in Great Britain, except: medicines, can be protected by the inventor or his legitimate representative in Argentina. 
Kinds of Patents :

(I) Patents of Invention. For new inventions not patented in any country previously are granted for five, ten, or fifteen years, according to wish of applicant and merit of invention. If a short term be applied for, it cannot be extended after action has been taken on the application by the patent authorities.

(2) Patents of addition to expire with the original patent.

(3) Certificates of Revalidation. Granted for inventions already patented abroad and expiring with the original foreign patent. These are not granted in any case for more than ten years. Inventions already at work in the realm cannot be validly protected in this way.

(4) Improvements. Granted for improvements on an existing patent, and usually expiring with it.

(5) Provisional. These are of little value, except to residents. They are kept secret, and can be renewed from year to year.

A patent granted in Argentina, Bolivia, Paraguay, Peru, or Uruguay carries with it provisional protection for one year in all the other of the above states. The Pan-American Congress, I9Io, unanimously passed a resolution to arrange a single Patent Office for the whole of Ameriea, except Canada and other European colonies. This has not yet been carried out.

A printed publication in any country before the application in the Argentine is fatal to the patent afterwards applied for, except the official publication of a corresponding foreign patent of the applicant.

There is an examination system, chiefly by independent experts, and a system of appeals is allowed in case of rejection.

In the case of patents of addition granted to other than the patentee of the original patent, the government assess the royalty he has to pay to the original inventor, and the latter can choose whether to accept such royalty or the two inventors can work the improvement freely in competition.

Patents can be opposed by interested parties on the ground that they have previously applied for the same invention, or that it is provisionally protected by them. In such case, if the two applications be found to be identical, both are refused till the parties can come to an agreement.

The invention must be worked in the Republic within two years from the grant of the Letters Patent, and working in the realm must not be entirely interrupted for two entire consecutive years except by circumstances beyond the control of the patentee or accident duly certified by the office, otherwise the patent becomes void.

In the case of machinery, working can be effected by working a machine imported from abroad. 
Infringement is a criminal offence, punishable with fine of from 50 to 500 piastres (about $£ 7$ to $£ 70$ ), or imprisonment of from one to six months. (Second offence within five years, penalty doubled.)

The counterfeit articles are also confiscated to the patentee, and the latter can obtain costs and damages from the infringer. The sole defences allowed are invalidity of patent or right of ownership in patent.

It is considered an aggravation of the offence if the infringer has been in the service or confidence of the patentee, or has obtained the information surreptitiously. Besides damages for infringement and the confiscation to him of the counterfeited articles, the patentee or informer obtains half of the fine.

Assignments can be registered, but all the annual taxes must be first paid.

Illegal use of the word "Patent," or exhibiting for sale (or even giving away) infringements on a patent, subjects the offender to the above-mentioned fines or imprisonment. These laws are easily put in force.

A bill for the protection of designs and models has been before Congress since 1907 , but has, we believe, not iyet come into operation.

Argentina is a very wealthy and pushing, and of late settled, state, with a magnificent railway system. Agricultural, wellboring, railway, milling, and household inventions are in demand.

There are annual taxes, payable always in January.

Trade marks can be registered.

\section{ASHANTI.}

Gold Coast patents cover this dependency.

\section{COMMONWEALTH OF AUSTRALIA, INCLUDING TASMANIA AND PAPUA (BRITISH NEW GUINEA).}

(Law of 22 October, I903, amended I906 and I909.)

Population, 5,500,000.

Who can Patent.-Any inventor, whether subject or alien, or his assignee, attorney, agent, nominee, or legal representative, or a person to whom any such individual being abroad at the time communicates the invention, or any two or more of these, may apply for a patent.

Kind and Duration of Patents.-(I) Provisional protection for nine months; (2) complete patent for fourteen years ; (3) patent for improvement to expire with the original patent ; and (4) cognate applications, that is, additions to provisional cases, are all granted as in Great Britain. 
The Examination System.-The examination system is practically the same as in Great Britain, but the Appeal from the Comptroller is to the High or Supreme Court, in the case of novelty being called in question, and to the Law Officer in other cases. Accepted applications are open to public inspection for three months for opposition by interested parties, and besides the English grounds of opposition (except insufficiency), the following can be brought against the patent, namely, that it is not new, that it has been abandoned to the public, or that the status of the applicant as regards his own title to the invention is not as stated. The invalidity of one or more claims of a patent has no effect on the validity of other claims. This is a very valuable improvement which under the law of Igrg has substantially been engrafted on to English practice.

The law as relates to novelty disclaimers, infringements, amendments, revocations of patents, compulsory licenses, remedy in case of groundless threats of legal proceedings, and practising patent agency without a license is practically identical with the British, but the Court has more discretion in favour of the patentee in case of proceedings for nullification of the patent on the ground that after four years' duration it is mainly or entirely worked outside the realm. All patented articles must be marked " Patent," with the number and year of grant.

About 4,000 applications for patents are made yearly.

Australia has joined the Union for the Protection of Industrial Property.

There are no annual taxes, but a single small tax payable near the end of the seventh year.

Designs can be registered for five years, renewable to ten and possibly fifteen years.

Trade marks can be registered. About 2,500 were placed on the register in Igrg.

\section{AUSTRIA.}

(Law of II Jan., I897, and 29 Dec., I908.)

Population, 9,500,000.

War.-See note under head " Germany."

Kind and Duration of Patents.-Patents of invention are granted for fifteen years, subject to an annual tax. Patents of addition are granted for improvements on existing patents, to expire with the original patent, and subject only to application fees and a tax of 25 florins to be paid within three months of the grant; but in case the original patent be revoked, annulled, or renounced, the patent of addition can be continued, as an original patent, to fifteen years from the date of the original patent, by payment of the taxes that would have been due on the original patent. 
Who can Patent.-The true and first inventor or his assignee or representative has alone the right of patenting an invention, but the first applicant will be considered the inventor till proved not to be so by the real inventor or his representative or assignee.

All contracts between employers and employees that the future inventions of the latter shall be the property of the former are of themselves null and void, but an employee can sell to his employer any given invention he may be possessed of.

What can be Patented.-Any new manufacture or process of manufacture can be patented unless it be (I) immoral or contrary to public health, (2) a medicine, (3) a disinfectant, (4) a chemical substance, (5) a food for human beings, or (6) appertaining to an article which is a monopoly of State. A process for manufacture of any article under the 2 nd, $3 \mathrm{rd}, 4$ th, and 5 th heads is patentable.

Novelty.-The invention to be patentable must not have been fully described in print in any country, publicly worked, exhibited, or previously patented in the realm. The Government can, however, by notice in the Patent Journal, exempt the official Patent Office publications of any given country from being considered publications under this head. Any one, however, who has privately used the invention before the date of the patent in his own works or elsewhere in the realm, or has made proper arrangements for using the same, can continue in such works to exploit the invention (for his own use or business only) without let or hindrance from the patentee.

Austria has joined the Union for the Protection of Industrial Property (see page 22).

Rights Conferred by Patent.-A patent confers on its owner the exclusive right to make, use, exercise, or sell the invention in the realm, and if it be for a process, this right extends to all products made by such process, even though themselves unpatentable. The Government has the right of using or appropriating in whole or in part, or of annulling, a patent relating to munitions of war or other patent likely to be useful to the state, and giving such recompense as with the assistance of experts it thinks fair to the patentee.

A person, however, proving that he himself had the invention at work in the realm before the application for the patent, even if the user be after the date claimed under the Convention, can continue to use it to the end of the term without paying any royalty, but such prior using does not make the patent invalid against other parties.

An application under the Convention in Austria must be made within twelve months from the date of the first application for a patent for said invention abroad, or if applied for within six months of the signing of the Treaty of Peace of the Great Warif patented in another country of the union since August I, I9I3, 
but without prejudice to rights of those parties who have got to work on the invention.

All applications for patents are examined by the official examiner (and by experts called in for the purpose, should the office require their services), and the applicant may be called upon to amend or subdivide his application. Against all decisions of the officials appeal can be had to the Patent Court.

Assignments and Licenses.-These can be made as in England, and registered, but till registered they are not binding on third parties, and they take effect in their order of registration, the first registered taking priority over a later registration, even though the last registered document was the first executed.

Compulsory Licenses.- If after the first three years of its duration a patent is not publicly worked by the inventor to sufficently supply the reasonable demands of the public, or another patentee has a patent which requires for its economical working the use of such prior patent, the patentee can be compelled by the Patent Office to grant licenses at reasonable rates.

Renunciations and Revocations.-A patent can be renounced by a patentee or whole or part owner, and thus the latter can escape all costs in subsequent actions for annulment, but such renunciation only affects the person making it, the rights of other owners of the patent being unaffected by it.

Working.-A patent can be revoked if the patentee do not work the same or make arrangements for others to work it to a convenient extent, and this even during the first three years of duration if the invention be worked abroad and the public interest demands such revocation. In practice the courts admit as proof of working at the termination of the first three years the mere commencement of working, such as making a distinctive part of the machine, but if this be not gone on with vigorously and the entire invention set to work, or if the inventor supplies the demand mainly from abroad, the patent will be declared void.

This revocation will not, however, be decreed until after the patentee has had due warning and has continued to leave the patent unworked, and can only be revoked at the suit of an interested party. If the patent be at work at the time the suit is brought it matters not that it was not worked during the first three years.

A patent can be annulled if it be found to have been illegally granted or the invention be not new or patentable at the date of the patent.

A patent can be transferred by a court to the rightful owner if it be proved that the invention was made by, and fraudulently taken from, another party claiming it.

Infringements are punishable by fine, by confiscation to the 
State of the infringing articles, and the payment of cost and damages to the patentee, and the publication of the sentence at the expense of the infringer. Where a patented process for a new article is infringed all articles of the same nature will be considered to have been made by the patented process, and be infringements until proved not to be such.

Any person can demand of the courts an authoritative decision whether any given manufacture he is engaged in, or intends to engage in, is an infringement of any given patent. This decision obtained is conclusive against the patentee.

Taxes.-There are annual and progressively increasing taxes to be paid on each patent of invention, otherwise it becomes void. These taxes must be paid on or before the anniversary of publication of the application for the patent in the Patent Journal, or within three months after.

Before the war about I2,00o patents were applied for annually, and about 5,500 granted. Household, electrical, milling, and, to a certain extent, chemical inventions are those most favoured.

Designs can be registered for three years, and designs which went void during the war are resuscitated. War time being a "dies non" as regards designs.

Trade marks can be registered.

\section{BAHAMA ISLANDS.}

(Law of 23 May, I889, and 3 March, I89o.)

Population, 60,000.

The true and first inventor can obtain a patent for seven years, renewable for another seven years, and then again for a third term of seven years, provided it was not known to any person in the colony at the time of application, except, of course, the applicant's own agent. It may have been well known elsewhere.

The patent is published before grant, and can be opposed.

Licenses have to be recorded to be valid.

The English Compulsory License Clause is re-enacted in the colony.

\section{BARBADOES.}

(Law of I9 March, I903.)

Population, 200,000.

Patents for new inventions are granted for fourteen years.

The annual taxes amount to $£$ I50 during the fourteen years. 


\section{BASUTOLAND.}

Population, 400,000.

A South African patent can be extended to Basutoland; the South African patent must be produced. Very few have been secured so far. There are small taxes payable in Basutoland at the ends of the third, seventh, and tenth years.

\section{BELGIUM.}

(Law of 24 May, I854.)

Population, 7,500,000.

Varieties and Duration of Patents.-Patents are of three kinds: (I) Patents of Invention, (2) Patents of Addition, and (3) Patents of Importation. Convention Patents, see page 22. Except in the case of Patents of Importation, a patent is null and void (Ist) if the invention has been accurately described in any printed book, circular, printed picture, or photograph, in any country, before the date of the patent or priority secured under the convention ; (2nd) if it has been worked commercially in the kingdom by other than the inventor or those holding rights under him before the date of the patent; (3rd) if there be at the time in existence, in Belgium or abroad, a patent for the same invention of date prior to that claimed for the Belgian patent.

A valid patent of importation, granted only for the nominal duration of an existing foreign patent for the same invention, can, however, be obtained by the patentee of the said foreign patent, or his assigns, so long as it has not been worked commercially in Belgium previous to date of application for the Belgian patent by parties not holding rights under the said patentee, or his agents or assigns. It may have been described in books printed by Government authority, but if fully described in print, in works other than official, before the date of application, the patent can be declared void.

Patents of invention are granted for twenty years, subject, however, to the payment of an annual progressive tax. Payment of these taxes must be made the day during which they become due, but can, in default, be made good by paying the tax and an additional fine any time within six months of the date they become due.

Patents of importation last only for the term of the foreign patent of longest duration, and are subject to the above annual tax, and limited by the term of twenty years from the date of application.

Patents of Addition are for improvements on existing patents, and can be taken out by the inventor of the original patent of 
invention or importation. They are granted free of annual tax for the remainder of the term of the original patent; but the annulment of the latter (except for non-payment of tax) does not entail the loss of the patent of addition, provided the taxes on the original patent continue to be paid. The owner of a patent of addition on a patent owned by another cannot work the original patent without a license, and vice versa. If, however, the original patentee declines to keep up the patent, the patentee of the addition can pay the annuities for him, so as to keep his own patent up, but even then cannot use the original patent without a license. There are hardly any cases of patents of addition being taken out except by the owner of the original patent, as in such cases the administration requires taxes to be paid by the owner of the patent of addition, and it is, therefore, better to apply for an original patent.

Novelty.-An invention must be new in the realm at the time of application of the patent in Belgium or (if an importation or "Convention" patent, see page 22) at the date of the original application abroad on which it is based.

If a part be proved old, and another part of the invention be new, and the combination new, even if all three be claimed separately, the entire patent is not nullified, but only that portion claiming the old part taken separately, the new part and the combination being still validly patented.

As in England but contrary to French law, the sale of products of the patented machine, or process, in the realm by the inventor, previous to the application for the patent, destroys the validity of a patent of invention for the said machine. Publicly exhibiting the invention does not destroy the validity of a patent afterwards obtained, nor the sale of articles made by the patented process or machine by third parties without the cognisance of the inventor.

Proof of private possession of the invention by a third party in the realm, and without the concurrency of the inventor, prior to the actual date of the patent, does not invalidate the patent, but gives the possessor a legal right to infringe the patent during its continuance.

Who can Patent.-All inventors, Belgian or alien, the assignees of said inventors, and practically others besides the true and first inventor, can obtain valid patents for inventions, provided they be new. Heirs or executors of a dead inventor can patent the invention imparted to them by the deceased.

If a patentee be proved to have obtained the knowledge of his invention from the true and first inventor by fraud, the real inventor can by law obtain the transfer of the patent rights to himself, or their nullification.

Procedure.-All patents applied for, if the documents be in proper form, and the fees paid, are granted without examina- 
tion as to novelty, and without guarantee of the Government as to sufficiency, validity, or merit.

The specifications and drawings must describe the invention so accurately that any ordinary workman in the trade to which it relates can work it without making fresh experiments; the drawings must be to metrical scale, and the specification must end with distinct claims. In this latter respect the Belgian law is almost exactly the same as the English and American.

The specification must also set forth exactly what parts are new and what old.

The patent dates from the hour of application in Belgium.

What can be Patented.-Any invention, discovery, or improvement, susceptible of being worked as an object of industry or commerce, can be patented, with the following exceptions.

Medical appliances, medicines and inventions for a curative or health-preserving object, cannot be patented in Belgium, but bottles, capsules, and surgical instruments, processes for making medicines and the like, also antiseptics and disinfectants can be validly protected.

So can veterinary medicines as such, but the patented article can be made and used for human beings without infringing on the patent.

Artistic and literary productions cannot be patented, but are perfectly protected under the decree I9 to 24, July I793.

Mere changes in form, quantity, material, or colour, cannot be patented unless productive of new results.

In a combination producing a new result the combination can be patented, but not the new result, and any one finding a new way of effecting that new result can obtain a valid independent patent for the new combination.

A discovery to be validly patentable must exist through human intervention-thus the discovery of a new mineral could not be patented ; the discovery that gas can be purified by passing it over a certain chemical could be validly protected.

One patent cannot be granted for two inventions entirely disconnected with each other. This proviso is construed more liberally in Belgium than in England and America.

Rights conferred by Patent.-Belgian patents give substantially the same rights to their possessors that English and American ones do in their respective countries. A patent is in all respects personal property. If several persons hold a patent in common, each has the right of working it independently of the others, unless otherwise arranged by special agreement; but should any proprietor prove that another is getting heavy profits that ought equitably to be divided between the co-proprietors-such as royalty for a license - a court of equity will rectify the grievance. A license, however, granted by a partial proprietor is valid. The patent gives the right to prosecute before the tribunals 
all those who make, import, or employ commercially, sell, or expose for sale, the invention patented. Personal use of the invention, when not commercial, is no infringement. The actual manufacturer-not the man who ordered the infringement-is the person to proceed against. The author, however, of plans and specifications from which the article is made, is held to be an infringer as well as the actual manufacturer.

If a machine be patented, but not its application, the maker or importer only can be proceeded against, not the user, even if he uses it for a commercial purpose. The possessor of a counterfeit article, or of apparatus specially designed for working a patented process, is legally an infringer, if it can be shown that the intention of the possessor of said article or apparatus was to commercially use the invention, even if no such use be proved. If, however, he possess these articles as security for debt only, or to use them only for his personal wants, and not to make a trade of them, he is clear of infringement.

Articles passing through the realm, in transit from one foreign country to another, are not liable to seizure; this holds good for nearly all European countries.

Working.-A patent can be declared null and void if it be proved that the patent is yet unworked by the inventor, his licensees and agents, or assigns, in Belgium, at any time after one year from the date of the patent, and if it has been worked abroad with the knowledge of the inventor more than one year previously; also, if said working be suspended continuously in Belgium for one whole year after it has been first worked abroad. This provision of the law is very liberally interpreted in favour of the inventor, it having been decided that the working of any part of the invention or of a patent of addition, and public exhibition of the invention in the country, or the importation of a part and granting of a license to manufacture, is a sufficient working. Practically the first working abroad must be effected within one year of the date when proof of working was made in any other country-for instance, in France, Germany, or Austria. The delay of one year can, prior to its expiration, frequently be prolonged another year by petition to Government.

Even if the invention be worked in a small way in the realm, if it be imported to a very much larger extent from abroad, the courts consider it has not been properly worked. To upset a patent under the working clause, a suit must be entered by an interested party.

Discontinuing working for a complete year also constitutes a ground for annulment.

In the case of patents applied for under the Convention, three years from the date of application is allowed in which to effect the working. 
Licenses and Assignments.-An exclusive license must be signed by the entire proprietary, and entails on the owners of the patent the obligation to prosecute infringers if required by the licensee.

Assignments and licenses of patent should, to be valid against third parties, be registered at the Department of the Interior ; or should obtain a "certain date" some other way (that is a legal proof of date). This can be done by obtaining the seal of a court, the attestation of a notary, the certificate of date of death of one of the signatories, or any other official document by which the deed can be proved to have been in existence at a specified date. Registration is not necessary in this case, but is useful, as the registration is officially published, this mode of obtaining a "certain date" is that usually adopted.

Licenses can also be registered. The registration fee in these cases is variable.

The vendor of a patent, in selling it, practically guarantees to the purchaser that his title to the invention is perfect, also that the patent is valid, and that everything mentioned in the specification is true; he does not guarantee in other respects the utility or success of the invention. Should any of these practical guarantees be vitiated, the purchaser can oblige the vendor to receive back the patent, and return the money. Unless a clear case of fraud be proved, these rights cannot be enforced anywhere but on French or Belgian soil.

Infringement Suits.-The penalties for knowingly infringing are :-The confiscation to the patentee of the counterfeit articles and all apparatus specially destined for making them, the value in money of all counterfeit articles already sold, and damages for infringement. The penalties for infringing through ignorance are an injunction from continuing the infringement and assessed damages.

The articles aforesaid can be seized, even when pledged to another.

The court can in all cases, if it see fit, and generally does, give the aggrieved party the right of publishing, by public advertisement, at the cost of the infringer, the full or abridged account of the trial and sentence.

Any one or more of the joint owners or licensees of a patent can become a party to an action for infringement before a civil tribunal.

Patent actions in Belgium are much cheaper and more quickly decided than in England.

If the plaintiff be resident abroad he must deposit with the court security for costs in money.

Annulling a Patent.-Patents can be annulled by the tribunals partially or entirely -if the description be intentionally obscure, or to incomplete or not sufficiently explicit for an ordinary person 
in the trade to which it relates to be able to work it without experiment or invention; if an important part have been withheld ; if it be not an invention of man ; if it be not commercial or industrial ; if it be contrary to public law or morals; if it be not new ; if it have been commercially worked in the kingdom prior to the date of the patent by parties unconnected with the inventor; or if the annual tax be not paid. The annulment of the foreign patent on which it was based before the end of the term for which it was originally granted does not nullify the Belgian patent of importation.

A patent is good until pronounced by the administration to be cancelled; such pronunciation is final, and cannot be appealed against.

Official Publication.-A description, embracing the essential points of every patented invention, is published by the authorities in the official Recueil special des Inventions-nominally three months after the grant of the patent. This publication is, however, usually a year or more in arrear. Until these three months have expired, the invention is kept secret by Government, after which any one can, on paying the cost of copying, obtain from the authorities a description embracing the entire substance of the invention.

About Io,500 patents of all kinds were secured yearly before the war.

Belgium for its size was probably the greatest manufacturing country in the world till the war, and is rapidly recovering from the affects of the " occupation."

Absolutely new models or designs can be registered for any number of years or in perpetuity.

Belgium, in a very full manner, extended the duration of all patents held during the war time, even those that went void during the war.

All patents, except those of addition, are subject to an annual tax on pain of forfeiture.

Designs and trade marks can be registered.

\section{BERMUDA.}

(Law of I8 November, r902.)

Population, I8,000.

The law is almost identical with the present English law, except that there is no provisional protection, or annual taxes. Designs are registrable for five years. Trade marks can also be registered. 


\section{BOLIVIA.}

(Law of 16 November, I9I6.)

Population, 2,800,000.

Any invention patentable in Great Britain, except medicines, can be patented in Bolivia for fifteen years, provided it is not known or published in any country. It is granted to the inventor, or his legal representative or assign.

Inventions already patented in other countries can be secured by the inventor or his assign as patents of importation, provided they be applied for within one year of the earliest application abroad, but the legal date in such case shall be that which corresponds to the foreign patent, and the patent shall expire with the foreign patent.

Patents of Addition can be obtained by the owner of the original patent for improvement thereon.

There are annual progressive taxes for patents of invention, and taxes, half the amount on each patent of addition.

Working in the realm must be proved before a District Judge and Prefect within two years of the date of the grant, but this period can be extended on showing sufficient cause for two years longer.

The ministry has power to expropriate a patent and indemnify the patentee.

The granting of a patent in the Argentine, Bolivia, Peru, Paraguay or Uruguay, gives provisional protection in the others of these countries for one year from the grant of such first patent. Also the publication of the invention in an official or officially certified exhibition is equivalent to provisional protection for one year. An inventor also can apply for a provisional patent for a term of one year which may be prolonged to two years.

Any person can apply for a compulsory license to work an invention if he can show that the invention has not been worked in the realm for two years, or has been abandoned for a time, and if his petition be allowed by the courts he pays a royalty of half his profits to the inventor, and any failure to do this is not merely a civil but a criminal offence. It is also a criminal offence to infringe a patent, the penalty being a fine of from Ioo to 2,000 Bolivians, or six months' to two years' imprisonment or both, at the discretion of the judge.

The patentee can also obtain damages and the sequestration of instruments, of machines and products made or employed in forming his rights.

Compulsory registration has been decreed for all trade marks used in [Bolivia to mark foreign goods, under penalty of a fine.

Term of registration-ten years, renewable. 


\section{BORNEO, BRITISH AND SARAWAK.}

Population, 600,000.

The Straits Settlements patent law has been adopted for this Colony.

\section{BRAZIL.}

(Law of $\mathrm{I}_{4}$ October, I882.)

Population, 24,300,000.

Kinds and Duration of Patents.-Patents of invention are granted for fifteen years from date of grant.

Patents for improvements on existing patents, free of annual taxes, are granted to expire with existing patent.

An invention patented abroad can be protected in Brazil by the inventor within seven or under the convention twelve months of the date of application for the original foreign patent, notwithstanding any publication during the interim; and such patent takes priority over an application by another inventor for the same invention during said interim, but expires with the original foreign patent.

Provisional protection for a definite period, six months to three years, is granted, if desired, before patenting, to an inventor desirous of experimenting in public or exhibiting his invention.

What can be Patented.-Any new industrial product, or new process, or new application of old process for obtaining an industrial product or result, or improvement on an existing patented invention, can be patented.

By nere is meant not in commercial use and unpublished in any country before application for a patent.

Procedure.-There is an examination before grant of the patent, stricter in the case of chemical, alimentary, or pharmaceutical inventions than with others, but only with a view of ascertaining if the documents be in order, whether the invention be dangerous to public health, security, law, or morality, and whether it be patentable. The question of novelty is little gone into. About 400 are granted each year.

In applying for a patent of addition the original patent on which it is based must be forwarded to Brazil.

Two or more inventions cannot be protected under one patent.

Rights conferred.-It is an infringement of the patent to make, sell, conceal, receive for the purposes of sale or import, the patented article, or use the patented process, and the penalty of such infringement is a fine of from $£$ roo to $£ \mathrm{I}, 000$, and ro to 50 per cent. of the real and constructive damages (and the forfeiture to the patentee, in aggravated cases, of the counterfeit 
articles and plant for their manufacture). When the infringer has been associated as an agent or employee with the patentee, it is considered an aggravation of the offence.

Co-patentees have equal and independent rights to use the invention.

The Government can at any time purchase the patent at a valuation.

Working.-The invention must be worked in a bona fide manner in the realm within three years of the date of the patent, and to such an extent as to supply the wants of the country and each part of it, at reasonable rates, and such working must not be suspended except in case of force majeure (a state of siege, for instance, preventing the working), on pain of forfeiture of the patent rights over that portion of the territory that, in the opinion of the authorities, was not properly supplied. Merely supplying the patented article made abroad and keeping a stock of same on sale is held to be working in most cases.

Improper use of word "Patent."-There is a fine of from $£ 20$ to $£$ IOo for the use of the word " Patent," or its equivalent, for any unpatented article, or article for which the patent has expired.

Taxes.-All Patents of Invention are subject to an annual tax at the end of the first year, and increasing a little each year. Trade marks are registrable.

\section{BRITISH CENTRAL AFRICAN PROTECTORATE.}

(Ordinance No. 9, I903.)

Population, whites, 700.

" coloured, 750,000 .

The law, taxes, practice, and costs are the same as the British in every important respect.

This Colony has joined the Union for the Protection of Industrial Property.

Taxes as in Great Britain.

\section{BRITISH GULANA.}

(Ordinance of 6 December, Igo2.)

Population, 3Io,ooo.

The British law with slight modifications has been re-enacted for British Guiana, the differences being that the assigns of inventors can apply for patents, that the fees are much heavier, and the annual taxes are changed to a single tax at the end of the seventh year. Duration of patent: fourteen years. 


\section{BRITISH HONDURAS.}

(See Honduras [British].)

\section{BULGARIA.}

Population, 5,000,000.

No patents are granted, but a law for the purpose is being considered.

Trade marks can be registered.

\section{DOMINION OF CANADA.}

(Revised statute, I906, and Ordinance of I6 May, I9r3.)

Population, 8,000,000.

Kinds of Protection and Duration.-There are two kinds of protection, patents and caveats (or provisional protections). Patents are granted for eighteen years.

In cases where an inventor, wishing to perfect his invention by experiment before applying for a patent, fears that others may forestall him, he may file a caveat, that is, a description of his invention, to be kept secret in the Patent Offices at Ottawa until such time as he patents the invention.

This caveat remains in force one year, and can be renewed as often as desired.

During the existence of the caveat, should another party apply for a patent for an invention infringing on that forming the subject of the caveat, the Government is bound to give the caveator three months during which to file his application for a patent, when, if the claims to the two specifications be found to interfere with each other, a court, consisting of three sworn arbitrators, is appointed to decide who is best entitled to the invention. The arbitrators, skilled persons, one chosen by each party and the third by the Commissioner of Patents, have power to compel the attendance of witnesses, to take sworn evidence, oral or written, and from their decision there is no appeal. A similar court decides all cases of interfering applications for patents; that is, cases where two independent applicants lay claim to the same invention. As an alternative the inventor may ask the Exchequer court to decide the question.

There is another form of caveat (provisional protection) which can be used when a patent has been applied for abroad. If this caveat be applied for within three months of the grant of the first foreign (or British) patent for the same invention and a patent be applied for in Canada within a year of the grant of the said first patent abroad, the Canadian patent holds good against infringers who began infringing during the period between the dates of the respective applications for the foreign and home patent. 
What can be Patented.-Any invention capable of being patented in Great Britain is also patentable in Canada. There is a search for novelty and an appeal from the examiners to the Commissioner of Patents and from him to the Exchequer court.

Patents for inventions previously protected abroad must be applied for in Canada within one year of the date of issue of the earliest British or foreign patent for the same invention, and within one year, also, of their first publication in any country. The Canadian officials have sometimes been very liberal on this point, and have, in urgent cases, accepted a telegraphed guaranteed application, by a responsible party, so that it might be officially entered within the required period. But it is not safe to rely on this. Any one commencing to work the invention in the Dominion prior to the date of the patent, or of provisional protection when that is applied for, can continue to use or sell the specific article so worked, in defiance of the inventor. But provided that working, etc., took place only within one year prior to the application, it will not invalidate the patent.

Who can Patent.-Any person being the true and first inventor, his executor, or administrator, can become a patentee, and can assign to others before issue.

The applicant for a patent is sometimes required, before the patent issues to him, to supply, if the case admits of it, a neat working model, on a convenient scale, but no more than twelve inches in any dimension; or, if the patent be for a composition of matter, a set of samples may be required, including a specimen of the composition, and of each of the ingredients used, except such as are disagreeable or dangerous to keep. These specimens must be neatly and separately packed in bottles and labelled. These are, however, seldom now required.

Working.-The invention must be "worked" in Canada within two years of the date of the grant, or such extension as may be officially authorised, and must be continued in " operation " to such an extent that any one can purchase the products thereof at a reasonable price, and at reasonable notice made in Canada, or the patent can be annulled at the suit of any party. But if before six months after the grant the patentee applies to have his patent placed under the compulsory license clause, no official " working" is required if his petition be granted, which is not always the case. In his petition he must show to the satisfaction of the Commissioner that it would be a hardship to make him " work" the invention in the time allowed.

The Commissioner has power to extend the time for working to four years, and the time for allowing importation to two years, on good reason being shown.

Compulsory License Clause.-If a patent placed under this clause be not worked sufficiently for the reasonable requirements of the public to be fulfilled, the Commissioner shall have power. 
on the application of a third party and after hearing the patentee, to grant a license to such a party to work the invention on such royalties and terms and with such restrictions as the Commissioner of Patents shall deem just. The patent will also be forfeited if it be proved that goods made on the principle of the invention were imported into Canada with the knowledge or connivance of the owner of the patent, or any of his assigns, licensees, or agents, after the expiration of twelve months from the date of the patent, or such extension of the period, not exceeding one year at most, as may have been officially granted, on special application. In November, I9I9, an Act was passed giving the minister in charge of the Patent Office very full powers to extend time for working, paying taxes, importation, or giving other relief in cases where the applicant or patentee or opposer has been prevented from doing any act by reason of a state of war.

Importing the parts of a machine and putting them together in Canada is held to be importing the invention from abroad.

Amendments. - If from any cause an inventor find that his patent is invalid by reason of its claiming parts that were old at the date of the patent, or that were the invention of others, or that he has inadvertently not claimed a part of the subjectmatter of his specification that he might have done, and would like to do, he can either file a disclaimer of the old portion or surrender his patent, and obtain a new one for the unexpired term of the eighteen years, or any part thereof, with fresh claims. The new or re-issued patent must, however, not contain any subject-matter other than set forth in either the drawings or the body of the original specification, or clearly shown by the model supplied with the application.

Government Use.-The Government of Canada may always use any patented invention, paying such royalty as the Commissioner of Patents may decide to be proper.

Assignments to be valid against third parties must be registered at Ottawa ; and if an inventor fraudulently, or by error, assign his patent to two different parties, the assignment that is registered first is the only valid one.

Infringers may be prosecuted for damages in the Court of Record of the district in which the infringement occurred. Such court can grant injunctions, damages and costs.

Deceit.-If anything be added to, or omitted from, a specification, with evident intent to deceive or mislead, the patent is void.

Marking Patented Articles.-All patented articles must be stamped "Patented," with the year of grant of patent, thus "Patented I9r4." Any patentee offering for sale any patented article not so marked is liable to a fine not exceeding $£_{20}$, or imprisonment not exceeding two months.

Any one fraudulently marking any article with the word 
"Patented," or any word or words of similar meaning, is liable to a fine not exceeding $£ 40$, or imprisonment not exceeding three months, or both, at the discretion of the court.

About 5,000 Canadian patents are issued per annum. Canada is rapidly becoming a first-class manufacturing country.

Taxes.-Patents are subject to taxes and other formalities, before the end of the sixth and twelfth years respectively, in default of which they become void. These payments can, however, be paid at the commencement, in which case no formalities are required.

Designs can be registered by residents only, for five years, renewable to ten. Trade marks are registrable.

Since this part of the book has been put up in type we have received a letter from our Canadian correspondent as follows :-

A Government Bill has been introduced in the Canadian Parliament which will no doubt become law in due course, and which will make the following radical changes in the law.

r. Canadian applications must be filed within one year of the date of filing of any foreign application, or within one year from coming into force of Act.

2. The restrictions against importation after one year will be removed. Importation after such period will no longer, in itself, render a patent void.

3. Working provisions similar to the new British Act are to be introduced.

4. All patents will be subject to Compulsory License.

5. Renewal fees will be abolished. The system of a final fee, as in the United States, will be adopted.

6. Patents on foods and medicines will be restricted to the special processes by which they are produced.

7. Public use before application, to defeat a patent, must be use in Canada.

8. Publication for two years prior to application will defeat a patent.

\section{CEYLON.}

(Ordinance No. I5, I906.)

Population, 4,I00,000.

The English law of 1883 , altered in administrative details to suit the Colony, was adopted by the latter in March, I906, all previous patent laws being superseded. The holder of an English patent may at any time during its existence apply for Letters of Registration in Ceylon to expire with prior English patent, but these are often refused.

Ceylon has joined the International Union.

There are no patents of addition. Annual taxes have to be paid on pain of forfeiture, but six months' delay is granted on payment of a small fine. 
'Designs are registrable for five years, not renewable. Trade marks are also registrable.

\section{CHANNEL ISLANDS.}

Population, roo,000.

In Jersey and Guernsey an English patent can be re-registered in the Royal Court of the respective islands. Trade marks can also be registered.

\section{CHILE. \\ (Law of 7 August, r9rr.) \\ Population, 4,000,000.}

Patents are granted to inventors or their assignees or official representatives for not exceeding ten years from grant for absolutely unpublished inventions. The term near its expiration is frequently extended on petition in the case of really meritorious inventions to not exceeding twenty years in all. Patents are granted for all new inventions patentable in Great Britain except foods, beverages, medicines, and pharmaceutical preparations. A patent for a process for manufacturing any of these is, however, patentable. Patents of Importation are granted for good inventions patented and in force abroad and not yet at work in the country. Each application, before being granted, is submitted to a scientific Commission or expert to decide whether it be novel and useful, and worth a patent. The deliberations are kept secret, and according to the decision the patent is allowed or refused by the General Director of Public Works; from his decision there is no appeal, but in cases where the scientific expert is clearly in error the General Director can revise his decision and we have had several cases where he has done so. If a patent be allowed, it is published, is open to opposition for one month, after which no opposition can be commenced against it unless it is applied for as a new invention and it really has been obtained from abroad and already published. A definite time is given to the patentee in which to start the manufacture, usually two years; this period, on good reason shown, can be prolonged once only by the Patent Office. In the case of an invention difficult to work in Chile, working can be performed by appointing an agent and advertising the fact. The ten years granted for the patent begin from the termination of the said term allowed for starting, and if, at such termination of term for starting, the manufacture be not in practical operation in the country, or if working be interrupted for one calendar year, the patent is annulled. A yearly certificate of working should be procured. Importing the patented article is usually held as satisfactory working if the patentee have an agent in 
Santiago for selling the patented article, but he must apply yearly for a certificate that he has. proved the working. A model specimen or photograph (of a machine) is usually required. Infringing a patent knowingly is a criminal offence, as is also the fraudulent application for a patent. The law is very favourable to the patentee against infringers. Trade marks are registrable. No annual taxes.

\section{CHINA, INCLUDING MANCHURIA.}

Population, 400,000,000.

The Chinese Government have decided to establish a Patent and Trade Mark Registration System, and a scheme has been laid before the Governments of Great Britain, the United States, and Japan, but nothing is really fixed as regards patents at date of going to press, and at present the condition of the country is too unsettled to think of it.

Trade marks can be filed and will take precedence in date when the law is passed. Patent applications can be registered at Shanghai, and will probably be taken in order of date when the Patent Office is established.

\section{COLOMBIA.}

(Act of 13 May, 1869, and Decree of 18 November, I9Ir.)

Population, 5,500,000.

Patents are granted to the true and first inventor for ten to fifty years at the option of the Government ; but to expire with any prior foreign patent for the same invention. There is no examination as to novelty or utility.

A patent for an entirely new industry must be worked within a year of grant, and working not suspended for a period of one year. It can be declared void if found to be an infringement of a prior-existing patent, or if not worked as above, or if it violates vested rights in existence at the date of application.

Colombia, Bolivia, Ecuador, Peru, and Venezuela have a treaty whereby a patent granted for the first time in any of them gives provisional protection in all the others for two years.

A very little constitutes working and a certificate is easily obtained.

Taxes variable in amount are sometimes levied on pain of forfeiture. Trade marks can be registered. 


\section{CONGO FREE STATE.}

(Law of 29 October, 1886.)

Population, probably about $15,000,000$.

The Belgian law, altered in a few minor details of procedure in taking out patents, etc., has been enacted for this State. Assignments and licenses to be valid should be notified to the Department of Foreign Affairs in Brussels. There are no annual taxes. Trade marks can be registered.

\section{COSTA RICA (REPUBLIC OF).}

(Law of 26 June, $\mathrm{x} 896$.)

Population, 460,000.

The inventor of an unpublished invention can obtain a patent for the term of twenty years, or if it be already patented abroad for the period (not exceeding twenty years) for which it has been so patented.

Infringers can be proceeded with both civilly and criminally.

The invention must be worked within two years of the grant of the patent and the working never discontinued for three consecutive years on pain of forfeiture. Trade marks are registrable.

\section{CUBA.}

(Spanish Royal Ordinances of 30 June, 1833, and 27 January, I873, and Decree of 31 April, r903.)

Population, 2,100,000.

Patents granted to inventor or assignee for seventeen years. To importers five years only are allowed and no extensions. Imported inventions can only be patented before being known in Cuba.

Separate patents are required for process and apparatus; working must be effected within five years from date of grant.

No annual taxes.

Designs, models, and trade marks can be registered.

\section{CYPRUS.}

Population, 306,000.

Patents can be obtained up to fifteen years for new inventions in the island. Trade marks are registrable. 


\section{CZECHO-SLOVAKIA.}

(Act of 27 May, r9r9.)

Population about 20,000,000.

Kind and Duration of Patents.-Patents of invention are granted for improvements on existing patents to expire with the original patent, and subject only to application fees, and a tax of 25 Frs. to be paid within three months of the grant. In case the original patent be revoked, annulled, or renounced, the patent of addition can be continued as an original patent paying the taxes on an original patent until fifteen years from the date of the original patent.

Pending applications made in Austria and Hungary before the publication of the Czecho-Slovakian patent law can be extended to Czecho-Slovakia on payment of the required fees and production of a certified copy of the original Austrian and Hungarian applications, subject, however, to the search by the Patent Office at Prague. In this case the Czecho-Slovakian patent has priority from the date of such original applications in those parts of Czecho-Slovakia originally Austrian and Hungarian respectively.

Czecho-Slovakia has not yet joined the Convention for the protection of Industrial Property.

There are annual progressively increasing taxes on each patent, except patents of addition.

In all other respects the law is exactly the same as the Austrian of 1897 and 1908, except that Czecho-Slovakian courts and officers are substituted for similar Austrian ones.

Trade marks are registrable.

\section{DENMARK.}

(Law of I3 April, I894, amended to I9I9.)

Population, 3,000,000.

There are four kinds of protection-Patents of Invention, Dependence, and Addition, and Registration of patterns or designs.

Patents of invention are granted for fifteen years for any new invention which can be utilised in industry, or become an object of manufacture, except medicines, foods, and methods of making food. By " new " is meant not yet openly applied in Denmark, or published in print anywhere to such an extent as to enable an expert in the trade to which it relates to work it.

Patents are granted to the inventor, or his representatives. or assigns (assignment legalised by a Danish Consul).

Patents of dependence for important alterations or variations on existing patented inventions are granted to the inventors of such alterations, but without right to use the original invention. 
Patents of addition are granted for additions to patented inventions, to the patentees of the original invention, to expire with the original patent.

A patent prevents others from importing, selling, or manufacturing the invention, or using the patented product without the consent of the patentee, except use on ships or vehicles temporarily in the country and fitted with the invention abroad.

All patents except those of addition are subject to an annual tax, on pain of forfeiture of the patent. If this be omitted to be paid when due, it can be paid within three months with an additional fine.

A patent can be purchased by the State, the amount being settled by arbitrators.

A Commission of ten members (with power to call in experts) examines all patent applications as regards novelty, utility, completeness, and clearness of description, and whether the case embraces more than one invention. The applicant has the right

ERRATUM

Page 78 , line 21: strike out " not yet."

11t case un successiuny passing the examiners is advertised and laid open to public inspection for eight weeks, during which it can be opposed, and in such an eventuality the Commission hears both parties.

A non-resident inventor must have a resident agent in the kingdom, and if that agent die or cease to represent the patentee, the latter must within a reasonable time appoint another representative willing to act, or the patent will be declared void. The representative of his local patent agent usually acts as resident agent until the inventor chooses to appoint another.

Licenses and Mortgages of patents are registrable.

Working.-A patent must be worked within three years of the issue thereof, and the working must not afterwards be discontinued in the realm for one whole year at a time, or the patent will be declared void. The Commission can however grant an extension of this time, or even relieve the patentee of the obligation to manufacture, especially where it is shown that the expenses of so doing are out of reasonable proportion to the demand in the realm, and that the patentee has arranged that the patented article can always be purchased at some place in the realm. 


\section{CZECHO-SLOVAKIA.}

(Act of 27 May, r9I9.)

Population about 20,000,000.

Kind and Duration of Patents.-Patents of invention are granted for improvements on existing patents to expire with the original patent, and subject only to application fees, and a tax of 25 Frs. to be paid within three months of the grant. In case the original patent be revoked, annulled, or renounced, the patent of addition can be continued as an original patent paying the taxes on an original patent until fifteen years from the date of the original patent.

Pending applications made in Austria and Hungary before the publication of the Czecho-Slovakian patent law can be extended to Czecho-Slovakia on payment of the required fees and production of a certified copy of the original Austrian and I

Trade marks are registrable.

\section{DENMARK.}

(Law of 13 April, I894, amended to I9I9.)

Population, 3,000,000.

There are four kinds of protection-Patents of Invention, Dependence, and Addition, and Registration of patterns or designs.

Patents of invention are granted for fifteen years for any new invention which can be utilised in industry, or become an object of manufacture, except medicines, foods, and methods of making food. By " new " is meant not yet openly applied in Denmark, or published in print anywhere to such an extent as to enable an expert in the trade to which it relates to work it.

Patents are granted to the inventor, or his representatives. or assigns (assignment legalised by a Danish Consul).

Patents of dependence for important alterations or variations on existing patented inventions are granted to the inventors of such alterations, but without right to use the original invention. 
Patents of addition are granted for additions to patented inventions, to the patentees of the original invention, to expire with the original patent.

A patent prevents others from importing, selling, or manufacturing the invention, or using the patented product without the consent of the patentee, except use on ships or vehicles temporarily in the country and fitted with the invention abroad.

All patents except those of addition are subject to an annual tax, on pain of forfeiture of the patent. If this be omitted to be paid when due, it can be paid within three months with an additional fine.

A patent can be purchased by the State, the amount being settled by arbitrators.

A Commission of ten members (with power to call in experts) examines all patent applications as regards novelty, utility, completeness, and clearness of description, and whether the case embraces more than one invention. The applicant has the right of being heard by the Commissioners and of correcting his case to suit their views, but the Commissioners, if the corrections be serious, can require the patent to be dated as of the date of filing the correction instead of that of the original application, and then can declare the patent void on the ground that the invention has been published in the interim. The Commission can also decide that the specification embraces two or more inventions, and can allow a part under the original application and allow the inventor to file another case (or more) for the remainder of the invention, to take the same date but with the fees paid again, always provided it be filed in the time specified.

The case on successfully passing the examiners is advertised and laid open to public inspection for eight weeks, during which it can be opposed, and in such an eventuality the Commission hears both parties.

A non-resident inventor must have a resident agent in the kingdom, and if that agent die or cease to represent the patentee, the latter must within a reasonable time appoint another representative willing to act, or the patent will be declared void. The representative of his local patent agent usually acts as resident agent until the inventor chooses to appoint another.

Licenses and Mortgages of patents are registrable.

Working.-A patent must be worked within three years of the issue thereof, and the working must not afterwards be discontinued in the realm for one whole year at a time, or the patent will be declared void. The Commission can however grant an extension of this time, or even relieve the patentee of the obligation to manufacture, especially where it is shown that the expenses of so doing are out of reasonable proportion to the demand in the realm, and that the patentee has arranged that the patented article can always be purchased at some place in the realm. 
Any interested person can bring an action to annul a patent on the ground of its interference with his legal rights; and if two persons apply for patents for the same invention, the first applicant is considered the rightful owner without very strong proof to the contrary.

Denmark has joined the Union for the Protection of Industrial Property, and the special papers requisite to obtain a patent under the convention can be supplied any time before the application is published. About 3,500 patents are applied for annually, about 2,000 issued. Agricultural patents are eagerly taken up in Denmark.

A registration of a pattern or series of patterns or designs in one packet is effected for three years or a multiple of three years up to fifteen years from first application, and if made for a shorter time can be renewed to fifteen years in all. For the first three years it can be kept secret if desired. Registration and renewals thereof can be effected by the owner or his assign. Registration becomes void if with the connivance of the proprietor of the designs or those having rights under him a copy of the design is imported from any country not "certified" by the King. The King can " certify" any country which grants protection for designs and allows of the owner of the design importing specimens from Denmark.

Penalty for infringing a patent or a registered design: two thousand crowns, first offence; four thousand crowns, with or without imprisonment, for subsequent infringements.

Agricultural inventions and industrial processes not involving large capital are in demand.

Annual taxes can be paid with a grace of three months on payment of a fine of a fifth of the amount of the tax.

Trade marks can be registered.

Designs can be registered for three years, renewable to fifteen years or any lesser term.

Renewal can be effected within three months after expiry on payment of a fine.

\section{DOMINICAN REPUBLIC.}

(Spanish Portion of St. Domingo Island.)

(Law of 26 April, rgrr.)

Population, 700,000.

Dominica has joined the Union for the Protection of Industrial Property and proposes to grant Patents. But the government is very unsettled, and very few patents are taken out. Trade marks can be registered. 


\section{DUTCH EAST AND WEST INDIES.}

Population, $35,000,000$.

Inventions in the Dutch Dependencies are protected under the Law of Holland. Curaçao and Surinam register trade marks. The remaining colonies, Sumatra, Borneo, Celebes, Java, and Madura come under one trade mark registration.

Patents for sugar manufacture and tropical agriculture are in most demand.

\section{EAST AFRICA PROTECTORATE.}

(Order No. I. of 7 January, I9r4.)

Population, white, 5,000.

$$
\text { " coloured, II,000,000. }
$$

A British patent can be extended to East Africa by the actual owner at any time during the life of such patent, the rights ceasing with the British rights.

Designs already registered in England can be protected to expire with the English protection.

\section{ECUADOR.}

(Law of I8 October, I88o.)

Population, 200,000.

The law, etc., of this country is similar to that of Bolivia.

\section{EGYPT.}

Population, r2,800,000.

British and other patents can now be extended to Egypt, to continue as long as the home patent lasts.

Designs and trade marks of British origin can be registered at Cairo by English firms for all Egypt and its dependencies, and are a good protection. No renewals necessary.

\section{FALKLAND ISLANDS.}

(Ordinance No. 2 of 25 February, rgo3.)

Population, 2,000.

Any person having or owning a patent, registered trade mark, or design for Great Britain can have the same extended to the Falkland Islands.

\section{FEDERATED MALAY STATES.}

(See Malay States.) 


\section{FIJI ISLANDS.}

(Ordinance No. 3 of I879.)

Population, 166,000 .

The law is very similar to the British as it existed in 1907 , but the initial costs are much greater. There are no taxes after grant, no compulsory licensing, and a patent falls with the earliest expiring British or foreign patent for the same invention. Duration otherwise fourteen years.

\section{FINLAND.}

(Ordinance of 2I January, $\mathrm{r} 8 \mathrm{~g} 8$.)

Population, 3,000,000.

Patents of invention are granted for fifteen years (and patents of addition to expire with original patent) for new inventions other than foods, drinks, medicines, clothes, or chemical substances-but a new mode of manufacture of any of these latter is patentable. By " new " is meant not published in the realm prior to application for patent, but if already patented abroad an invention is held as new in the realm if not published more than six months. There is an examination and publication, and oppositions can be filed.

Only one invention is allowed under one patent, and the Danish rule, which see, is followed if the case be divided.

There is an appeal to the Senate against any decision of the Patent Office.

If an invention requires the use of a previously patented invention for its successful working, it is still granted, but the fact and the number of the prior patent are set forth in the patent. Appeals are allowed from the decision of the examiner. There is a compulsory working or license clause very like the German, with, like the latter, a three years' limit.

But importing the invention from abroad is sometimes held an extenuation of the " offence" of not working, and the courts are very liberal to the patentee.

Finland is a great manufacturing country for cotton, wood, and iron goods.

There is a small annual tax, and three months' grace is allowed for payment of taxes with fine. Trade marks can be registered.

\section{FRANCE AND COLONIES.}

(Law of 5 July, I844, and I July, I906, and others.)

Population [France], 4I,500,000.

[Dependencies], 55,000,000.

Kind and Duration of Patents.-Patents of invention are granted for fifteen years, but fall void with any prior foreign 
patent for the same invention, except when obtained in countries which have adhered to the International Union, see page 22.

Certificates of addition are granted for additions to, or improvements on, any existing patent, and to expire with the same.

The duration of patents can only be extended by special Act of Legislature, very rarely obtained.

Who can Patent.-Any one, citizen or alien, being the true and first inventor, his executor, administrator-or in practice any legitimate possessor of the invention-can obtain a patent. If two join in the invention, it must be taken out in their joint names, and each has the right to use the invention independently of the other. In applying for the patent, no oath or declaration is required, as in England and the United States, but the applicant is considered the true and first inventor till proved the contrary by the rightful owner of the invention. An inventor who has assigned his invention to the party who patents it, is debarred, by that assignment, from contesting the validity of the patent, but such assignment, if made out of the Republic, must be legalised by a notary and French Consul to be accepted in French courts without other evidence.

A public functionary cannot legally patent an invention relating to the branch of service in which he is directly employed, but he can patent an invention in another line.

For the first year of the existence of a patent no one but the patentee, or others holding rights under him, can obtain a certificate of addition based on the said patent, but any one during that period can cover an improvement on the said invention by an independent patent, but he must file a secret patent application for such an improvement. In the latter case, if the improvements be not claimed by the original patentee before the expiration of the said year, such patent or patents are granted to their respective applicants in order of priority of application. In such cases, neither the owner of the original patent nor that of the certificate of addition, can use the other's invention without license.

After the first year of the life of a patent any one can obtain an independent patent for an improvement on the invention.

If specially asked for, a delay of one year from the date of application is allowed before the patent specification is made public, but no action for infringement can be commenced before the publication of the patent.

Subject to the above, the specifications with their drawings are now printed and published immediately after grant, and can be purchased at the Patent Office. One copy is, however, sent free to the patentee, who has three months to point out any errors that there may be in it, when they will be corrected. After this period the document will be considered as an authentic copy of his specification. 
Patent specifications and drawings are now published (unless a delay as aforesaid has been specially petitioned for) in separate form immediately after grant.

See also "Union for Protection of Industrial Property," page 22.

If one man employs another to invent, the employer is legally the true inventor of any resulting invention.

Also the inventions of engineering, technical, and other employees, relating to the trade in which they are employed, belong to their employers, but a mere workman making an invention can patent it and it remains his property.

Rights conferred by Patent.-A patent gives the sole right of making, selling, or using for commercial purposes the patented article or process on French territory, and of preventing the importation of the articles patented, or made by patented process.

A patent cannot extinguish rights already existing at the date of the patent ; consequently, if any person be secretly in possession of the patented invention and using it at the date of the patent-though such use will not invalidate the patenthe can continue to use it during the entire period of the patent in defiance of the patentee.

During the continuance of the patent the inventor can make additions to his specifications at any time, obtaining a certificate of addition therefor, to expire with the original patent, and not subject to any other tax than that paid on applying for the certificate.

Certificates of addition secured by a person having an interest in the original patent form parts of the principal patent in the eye of the law, and the registered purchaser of a principal patent can enter an action for infringement of a certificate of addition, granted to the original patentee of the principal patent, though the certificate be not mentioned in his deeds of transfer.

If the owner of a patent, after being shown or convinced in any way that his patent is invalid, use it as a means of menacing his rivals in trade or their customers, he is liable to fine or imprisonment under the criminal code.

What can be Patented.-As a rule, any new industrial product or new means or new application of old means for obtaining an industrial product can be patented.

The following are not patentable, however :

I. Pharmaceutical compositions or remedies of any kind, the said objects remaining subject to the special laws and regulations for these matters, and especially to the decree of August I8, I8I0, relating to secret remedies.

2. Schemes and combinations referring to credit and finances.

New designs (not involving any inventive talent or any new principle or new result) cannot be validly patented, but can be 
protected by filing them at the Secretariat du Conseil des Prudhommes (see "Designs," page 92).

Ornamental and other designs in sculpture are fully protected without such filing under the law of July I9, I793.

The following have all been decided to be patentable inventions, provided they produce a nere industrial result :

(a) A new process for producing an old article.

(b) A new application of a known means or process, or the application of a known means or process in a known way to an entirely different industry.

(c) The new practical application of a known chemical fact or theory.

(d) The new combination of two or more old parts or old processes.

(e) The mere alteration of the order in which certain steps in a known process are taken.

(f) The mere alteration of relative proportions or quantities, or even degree of temperature at which an old combination, compound, or process is worked.

(g) The mere omission of one part of a known process, or of one ingredient in a known compound hitherto supposed to be necessary to that process, or to the purposes for which the compound is applied, is patentable, if it produce the same result as the complete combination did, while saving the expense of the discarded part.

The mere use or employment of an old article in a new way, or the use of a machine or process hitherto used for manufacturing one substance-say, linen-for manufacturing another material - say, cotton or silk-is not patentable, unless a new industrial effect is produced thereby not analogous to that produced heretofore.

Similarly, mere changes of form, dimensions, or materials are not patentable, unless they produce a new industrial result, or a novelty in the process.

A greatly superior yield, if directly resulting from the alteration or change, is a new industrial result ; but the mere cheapening or improving of a known product, by greater skill in manufacture, is not a " new industrial result."

A new industrial result is not patentable in itself, but only the means or process by which it is obtained, or the new product resulting therefrom.

A new industrial result need not be useful in order to be patentable ; it is sufficient that it be novel ; and in an action for infringement it is no defence that the patent infringed is useless; but this point can be considered by the judge in estimating damages.

The juges $d u$ fait have, in the first instance, the decision as to whether an invention be validly patentable, and from them appeal can be made to a superior court. 
The patent must be limited to a single principal object, with the details that constitute it, and its applications, which should all be carefully enumerated and described.

In practice, the officials are generally liberal on the point as to what can be patented in one application, but some persons who have been in charge of the Patent Office have been much stricter than others. As a very exceptional case, we once obtained a patent for a Liverpool inventor, having more than three hundred drawings, and corresponding letter-press, the principal object being the manufacture of salt, and the objects of detail being the arrangements of plant and details of about forty different varieties of machines for treating salt. It was, however, by far the most voluminous specification for which a patent has ever been granted by the French Government, and is even now exhibited at the Ministry as a curiosity.

Such a case could not occur now, as the French authorities now confine the drawings to eleven figures and a short specification.

Should the Minister reject the demand, there is an appeal to the Council of State or a fresh application or applications can be made within three months of the rejection, and will be valid even if published in the meantime.

If, however, this delay of three months be exceeded and the invention has meanwhile been published, the patent is invalid for want of novelty.

If a patent be once granted, it cannot be annulled afterwards on the ground that it contains more than one principal object.

In patenting a process as the principal object, the obtaining and purifying of various by-products can be claimed.

Novelty.-For the patent to be valid, the invention must be " new," that is, must not have been publicly used or described in any printed book in any country, or in any manuscript open to public inspection in any public library or patent office, in any country, before the date of the application or of priority obtained under the Union for the Protection of Industrial Property, of which France is a member (see page 22), in such manner that from the description a man skilled in the trade could understand and work the invention. A French patent must therefore always be applied for on or before the date on which the English final or complete specification is accepted, the German patent is allowed, or American patent issued, except in cases where the protection of the Union for the Protection of Industrial Property for the time being protects the inventor. The fact of an invention proving extremely valuable on being introduced to the trade is, as in England, primâ facie evidence of novelty.

Mere experiments, or secret use prior to the application for the patent, do not nullify it, unless proved to have resulted in commercial success. Thus a patent for the manufacture of a 
pigment was held valid after it had been proved that the whole process had been published prior to the date of the patent as a laboratory experiment.

So long as any part of a patented invention be not proved to be old, or otherwise invalidated, the patent for that part of the invention is valid, even though all the rest have been declared null and void by a court of cassation.

Licenses and Assignments.-A patentee may transfer the whole or part of the proprietorship of his patent.

The transfer of the whole or part of the patent, either gratuitously or for a consideration, can only be effected by a notarial deed and after the payment of the whole of the prescribed taxes otherwise payable annually.

It is the general rule, but not an absolute one, that no transfer is valid as regards a third party before it has been registered at the Secretary's office of the Prefecture of the Department in which the deed has been executed.

The registration of transfers and all other acts concerning mutation are made on the production and deposit of an authenticated extract from the deed of transfer or mutation.

A copy of each declaration of registration, together with the extract from the deed above mentioned, must be forwarded by the Prefects to the Minister of Agriculture and Commerce within five days of the date of the declaration. These can be inspected and copies obtained at the Ministry.

There is no penalty for non-registration.

If a patent be sold many times over, and the final owner register the successive transfers (having previously paid up the taxes to the end of the fifteen years' duration of the patent), such registration is sufficient, though all the previous transfers escaped registration up to that date.

If two parties innocently purchase the same invention from the registered owner, and the second purchaser in point of time registers his transfer first, fulfilling all the formalities required, he becomes the actual owner, and his purchase, except in special circumstances, is usually held good, even against an unregistered earlier purchaser of the same invention from the same former owner.

The purchaser of a patent leaving his title unregistered for a long period, and then registering it, becomes at once the lawful owner of the patent, if there be no prior registration against him.

A transfer is valid as regards the actual parties to that transfer, without registration.

The unregistered owner of a patent cannot bring an action for the infringement of that patent.

If, however, in the case of an unregistered transfer, the registered owner join the actual owner in an action against any infringer, they can obtain damages. 
If a transfer of the rights in an invention takes place before application for a patent, and the purchaser takes out the patent in his own name, the transfer cannot be registered, but must be made before a notary, and (if outside the realm) the notary's signature legalised by the French consul, and should be preserved ready for production in case of any one bringing an action to upset the patent on the ground of the patentee not being the inventor.

A patentee selling a patent guarantees, by such sale to the person buying it from him (but not to subsequent owners), that it is, as far as he is able to ascertain, valid; that the statements contained in the specifications are true ; and if it be afterwards proved that any part or the whole of the specification be untrue, or that the product cannot be obtained by following the description of the process described, a judge can decree the annulment of the assignment and the restitution of an aliquot part or the whole of the purchase money.

If, however, a patent be sold for a given annuity during the continuance of the patent, or for a given royalty on the product, and it be afterwards declared void, the vendor cannot be made to refund past payments, but, with the nullification of the patent, the contract ends.

Until, however, the nullification be pronounced, the contract is good, and royalty due up to the date of nullification must be paid by the licensee.

It is customary, nevertheless, in cases of assignment or license, for a special clause to be inserted binding the patentee to return the purchase money in case the patent be declared null from other cause than non-payment of taxes, subsequent non-working, or expiration of term granted.

Should a part of the patent be nullified, a proportionate part of the purchase money can be similarly exacted by order of a court. A licensee is, in like manner, protected to the extent of the consideration paid for his license, but not for royalties already paid.

On the annulling of a patent, all licenses become void.

A patent can be seized for debt.

A patentee selling a territorial right (his rights for Normandy, for instance), or a part or the whole of his patent, can recover damages if the assignee of that part exceeds his rights or sells beyond his territory; but he cannot, except in special cases, seize the goods so sold, or prosecute other parties using them, as the latter purchased them from a licensee, and were not supposed to know the extent of the license.

The license of a patent, even for a share of the profits, does not constitute a partnership between the parties, unless there be a special clause to that effect; and if the licensee do not fulfil the terms" of his license, the Tribunal of Commerce can annul the license. and decree damages. 
If a partnership in a patent be dissolved, any one of the partners can appeal to the Tribunal of Commerce to have the patent sold and the price obtained divided; but if the partners agree that each shall work the patent independently of the others, then neither of the co-owners can from thenceforth claim the protection of the tribunal in this way.

Should a patentee, a member of a firm or company, sell his patent to that firm or company, he is still the owner of the patent as far as third parties are concerned, until the transfer is registered.

Certificates of Addition are refused for objects different from that of the principal patent. Thus, if the latter be for a product, and the certificate for a process of making that product, or vice versâ, the certificate is invalid; but an addition to the process, or an alternative sub-process to form a part of that originally patented, provided it be operative to the same end, or an improvement on the product claimed in the first instance, can validly form the subject of a certificate of addition.

A certificate of addition granted to any shareholder or licensee of the original patent becomes the joint property of all the proprietors in the same proportion as the original patent.

Amendment.-A patent invalid by reason of insufficiency or other defect in the description cannot be made valid even by a certificate of addition, though the added specification supplies the deficiencies of the original one, and makes it clear. Inexactitude is as bad as insufficiency of description, and equally nullifies a patent, even when unintentional.

Working.-The patentee whose invention is not worked and who does not make bonâ fide efforts to work it within the realm within two years from date of grant (three years from date of application, if taken out under the Convention of the Union for the Protection of Industrial Property), or who abandons the working of it for two consecutive years, and is unable to justify his inaction before a court, loses all right to his patent.

If any one "work" the invention during the two years it suffices, it being immaterial to the question whether the inventor licensed him to do it or not.

Working of an invention in part has been held sufficient; working a machine having a slight difference in design, but the same in principle to that patented, will be sufficient working. Substantial efforts to get the trade to take it up, advertising the invention for sale, and exhibiting it on a public exhibition, all severally constitute sufficient working to satisfy the law.

It is desirable to have proof of working registered within the two years following the grant of patent, or if obtained under the Convention three years from application, and if the inventor cannot arrange it in time the Patent Agent usually attends to it at a reasonable charge. Poverty, the fact of the patent 
being held an infringement of an existing patent, and that there was no demand for the invention at the time, have each been held sufficient excuse for not working a patent during the term allowed, but it is not safe to rely on these grounds.

Exhibiting the invention publicly and advertising it with a view to get a license is of far more value than making a single part of the invention and getting a notary to declare to it-at one time the commoner way of making an official " working."

Infringements.-Every interference with the rights of a patentee-either by manufacturing products or by using means forming the subject of his patent-constitutes the offence of an infringement.

That offence is punishable by a fine of from one hundred to two thousand francs $(£ 4$ to $£ 80$ ). The patentee can also bring an action for and obtain damages from the infringer.

An imprisonment of from one to six months may also be inflicted whenever the infringer is a workman or person employed at the workshops or in the establishment of the patentee, or whenever the infringer, after having gone into partnership with a workman or a person employed by the patentee, has become acquainted through the latter with the processes described in the patent.

In the latter case the workman or person employed may be prosecuted as an accomplice.

It is an infringement of a patent for a new product to make that product by a different process from that set forth in the patent specification, or of different ingredients or materials.

It is an infringement the making of a product or the working of a process differing in unimportant details from that protected, but involving the principles of the patent. If an invention be for a combination of old parts, it is an infringement of the patent to manufacture or import those parts separately with a view to their being put together to form the invention.

It has been held an infringement of the patent to repair or renew, without license, worn-out parts of a machine originally purchased from the inventor.

Working the invention for one's own personal use is an infringement.

If a man infringes a patent while in the employ and at the command of another, the latter alone is liable for infringement.

A licensee who goes beyond his license is liable for infringement.

Articles seized from the inventor for debt can be sold and used without infringing.

If any one, prior to the date of the patent, possessed the patented article in France, he has the right to continue to use it throughout the duration of the patent without being accounted an infringer.

Actions cannot be maintained for infringements made more 
than three years prior to the commencement of lawsuit ; but if the infringements have been continuous, or repeated over a lengthened period, and a part of them have been committed within the three years, an action can be brought for the entire series. But an action must cover all the infringements up to the date of action; and after the suit at law no further action can be brought against the defendant for infringements made prior to said suit.

It is sufficient defence of an infringement that the part of the patent which is alleged to be infringed was, prior to the date of the patent, published in any country sufficiently to enable any one to work it, or described in a prior patent which has fallen into the public domain, or of which the plaintiff has not acquired the rights, if still in force.

The patentee can obtain as damages in a civil action all profits that could have been made on the articles counterfeited, and satisfaction for injuries to his business that he can distinctly prove to be caused by the infringement.

The carriage of a patented article made abroad, in transit through France, is an infringement, even if destined for export to another country-thus the patented articles made in a country where there is no Patent in force, if sent through France to another country, can be stopped and confiscated at the French Custom House.

Importation of Patented Articles.-A patent can be annulled if it be proved that the inventor, his agents, or any one with his or their connivance, has imported into the realm a specimen of the patented article manufactured abroad. France has, however, joined the Union for the Protection of Industrial Property, and by so doing has agreed that this clause shall be inoperative against patentees of the other nationalities of the Union (which includes Great Britain and the United States).

In a trial, where a man in Paris contracted with an American inventor to manufacture the American's invention in France, and supply it at a given price to the American's customers, and the contractor, instead of so doing, employed an agent in the United States, before that country joined the Union for the Protection of Industrial Property, to buy from the inventor and forward the machines to Paris, where they were regularly supplied, at sale price, by the contractor, it was held that this did not invalidate the patent, and that the patentee was not bound to interfere in the matter, but could, and, in fact, did, allow this singular trade to continue, to his own and the contractor's benefit.

The Minister of Commerce and Industry can authorise an inventor, citizen of a state not in the Union, to introduce a single specimen of his invention by official permit; such permits can generally be easily obtained. During the régime of one Minister of Agriculture they were, however, almost uniformly refused. 
Importing the material for manufacture does not affect the patent. The article imported, to do any harm, must be in such a state of completeness that, if made in the realm, it would be held to be an infringement of the patent.

Nullification.-Any interested party can enter a suit to have a patent declared null. Any inventor in the same branch of industry is an interested party in the eye of the law.

A patentee can withdraw his application at any time within two months of the date of filing, when a small part of the fee will be returned.

Marking Articles.-Whoever in his advertisements, prospectuses, labels, stamps, etc., uses the word "breveté" or " brevet" (patented or patent) in connection with the patented article, without adding the words "sans garantie du gouvernement" (without guarantee of the government), is liable to a fine of not less than $£^{2}$ or more than $£ 40$. In the event of a repetition of the offence the fine may be doubled. The initials "s. g. d. g.," though almost universally used, have been held on one occasion not to be sufficient. Any one using the name, title, or trade mark of an inventor without his sanction, or marking a thing "patent" that is not patented, can be made to pay damages to the owner of the patent nearest resembling it.

Specifications are now printed and published separately (and without waiting for two years and then publishing them in the volumes as was the case till I90I). The inventor can get a number of copies of his own patent soon after publication at a lower rate than the public at large.

Taxes.-A patent is subject to an annual tax, payable before each anniversary of the application, on pain of forfeiture of the patent.

This tax can be paid all at once, or by instalments, at any time. If by any chance the annual tax be not paid when it becomes due, it can be paid any time during the ensuing three months on payment of an additional fine.

There are no annual taxes on certificates of addition, but these become void with the principal patent on failure to pay the tax on the latter.

If a principal patent and a certificate of addition thereon be separately owned, either party can pay the taxes to prevent the original patent (and consequently the certificate of addition) from falling void. Neither, however, can force the other to pay his quota. If both parties pay independently of each other, the Government will return the second payment on production of the first receipt. There are no means of knowing whether a tax has been paid or not during the current month, but information of all payments up to within a month of date can be obtained on application at the Ministry of Agriculture.

Designs or Models.-The inventor or author of any new 
design or model or set of designs or models packed in one box, or his representatives or assigns have the sole right of making and selling like models, etc., or box of them, provided such design or model be registered and deposited at the Secretariat of the Conseil des Prudhommes of the Department of Seine, or of such Department as the inventor if in France may be resident in. The registration lasts for five years, and if at the end of five years the owner asks for it to be re-registered, this can be done for twenty years more, and at the end of that time for a further period of twenty-five years.

These designs and models are kept secret for five years, and at the request of the owner for any extended period or part of an extended period, but the owner cannot sue for infringement until the design or model be published. He can however request at any time the Government to publish the invention. The designs or models must be such that they could not be validly patented, otherwise the registration is of no effect. Any number of designs or models up to Ioo can be placed in the same box, and deposited at the Conseil des Prudhommes at the same time, and a single charge is made for each box of models, the inventor supplying the box and sealing the same with his own seal and paying the cost of transit to Paris. He can, at small expense, have the designs published, or keep them secret as he prefers. The penalty of infringing a published design is from $\ell^{\mathrm{I}}$ to $\ell^{80}$, and if the person has been already found guilty of a similar infringement, or was in the service of the owner of the design and knew about it, he is liable also to imprisonment of from one to six months.

About 16,000 original patents are granted annually in France, and the number so far issued is close on to half a million.

Like many other countries, France granted extensions on patents expiring during war time through force majeure.

Trade marks can be registered.

\section{GAMBIA AND PROTECTORATE.}

(Enactment 5 of I May, I9oo, and Ordinance No. 5 of 3 March, 1904.)

Population, 146,000.

The law is very similar to the British of 1883 , with these exceptions. An assignee can apply for a patent and the holder of a patent in any other state or colony can get that patent registered for Gambia for the remainder of the period for which such foreign patent was granted. The fees are double the fees exacted in Great Britain. Gambia has joined the Union for the Protection of Industrial Property. From June to October business is practically suspended, as it is the bad season.

Trade marks and designs can be registered. 


\section{GFRMANY.}

\section{(Law of 7 April, I8gr, and 3 I March, I9I3.) Population, 65,000,000.}

During the war Germany, while allowing applications by alien enemies, did not issue the patents. , These have, since the war, been issued, and by a Treaty, Britishers, French, Italians, Belgians, and Americans are allowed, for six months from the declaration of peace, to apply for patents and designs that could have legally been applied for under the Convention at any time since April I, I9I4. Germans have made much more use of the corresponding clause than the English-speaking countries. Great Britain, indeed, has lately construed the clause not to apply at all in those cases where the applicant was not almost forced by the war to forego applying for the patent. No actions for infringement can be brought by an alien enemy ; taxes of patents which have gone void since July $\mathrm{r}$, I9I4, were payable in the first half of 1920 , thus revalidating the patent if its normal duration has not expired.

Kinds and Duration of Protection.-There are four kindsPatents of Invention, of Addition, Registrations of Designs and Patterns. The first last for fifteen years subject to annual taxes. The second (additions to or improvements on existing patents) are granted to expire at the date when the original patent would expire-the taxes of the original patent serving for both. The third for three years renewable for a further term of three years for novelties of useful design. The fourth for fifteen years. These two latter will be treated in a paragraph to themselves, the following information applying only to the first and second class of patents.

Who can Patent.-Any person the true and first inventor or his assigns, and practically any applicant with the connivance of the inventor, can obtain a patent.

A person outside the realm can only obtain a patent through a representative in the country. This person, usually the correspondent of his local patent agent, represents the patentee in all civil law suits, and can enter criminal suits for infringing said patent.

What can be Patented.-Any invention permitting of an industrial exploitation, with these exceptions-foods, drinks, medicines, chemical products, and finanical schemes. Where, however, a new chemical process is patented, the patent is held to cover such products as are directly manufactured under that process. In the case of imported articles, where there is good reason to suspect that they are made by a given patented chemical process, the burden of proving that they are not so. rests with the importer, and in default of such proof they are 
held to be infringements. Two separate inventions cannot be granted under one patent. This rule is rigorously enforced.

Novelty.-For a patent to be valid the invention must not before the date of application for the patent have been publicly used in Germany, or published in any book or public print, within a hundred years prior to the date of the patent, to such an extent as to enable a person versed in the trade to manufacture it. After five years a patent cannot be upset for want of novelty.

Germany having joined the Union for the Protection of Industrial Property, patents taken out under the Convention and based on any foreign application applied for within the previous twelve months are not invalidated by publication after the application for such foreign application, but a patent is without effect on any person who has worked or made the necessary arrangements for working the invention in Germany prior to the application for the patent. Such person can continue using the invention in his own or other workshops according to the requirements of his own business, and if he sells his business this right to use the invention passes to his successor.

Official publications of certain countries which have granted reciprocal privileges are not considered publications within the meaning of the above clause till three months after their issue. Neither Great Britain, her colonies, nor the United States are in this category at present.

The first person who applies for the patent gets it, irrespective of whether he be the inventor or not, with this reservation-if the applicant be proved to have obtained the invention surreptitiously or without permission from the description, drawing, models, or devices of another, that other can get the patent annulled, and on application within a month after said annulment can obtain a similar patent for himself, with a date prior to the day of publication of the original patent.

Examination.-All inventions are rigidly examined in regard to novelty by the Examination Department of the Patent Office, and many inventions which would pass the United States examiners or a British court of law as novel are refused because the principle of the invention is old, or the claims are mere combinations showing no new principle. If an application be allowed, it is published and is then open to opposition for two months before being granted; even those applications that are refused on opposition are published, but in any case the applicant on petition can get a delay of publication of three or even six months.

Oppositions and Petition for Annulment of patents are heard by the Patent Office and not by courts of law. For this purpose the Patent Office is provided with a large staff of judicial and technical experts divided into the application, annulment, and appeal departments. These three are entirely distinct, members of the application department not being allowed to have anything 
to do with appeals or annulments, and those of the other departments having no voice in granting applications (except, of course, when these applications have been refused and the decision is appealed against). Outside experts may be called in, but are not allowed to vote. The examiners of the application department are appointed for life. By this machinery there is abundant provision made for appeals from the primary examiner to the rest of the application department, and from them again to the appeal department. In the case of actions for infringement and for nullification there is also an appeal from the appeal department to the Imperial Supreme Court of Leipzic. These actions are cheap and very fairly conducted and ably decided.

An application is refused if found to be (I) not new ; (2) not a patentable invention; (3) not drawn up in accordance with the requirements of the law and the applicant declines to amend it ; (4) contrary to law and order ; or (5) if it be proved that the invention was abstracted from the specifications, drawings, models, implements, devices, or manufacture of another.

Rights Secured by Patent.-A patent gives the sole right to make, use, and sell the invention. A patent once granted is guaranteed by the Government until a successful suit be brought against the Patent Office to annul the same, and it is no defence in an action for infringement that the invention is not new, not sufficiently described, or not patentable.

The penalty for knowingly infringing a patent is a fine up to 5,000 marks, or imprisonment not exceeding one year, and the indemnification of the injured party. The patentee has also the right of publishing the verdict of the court at the expense of the infringer.

In a case of the infringement of a patented process for manufacture of a new material, all materials of a like nature are considered as made according to the patent until proof be produced to the contrary. It is no defence in case of infringement that the patent is bad; but the infringer can usually get the case delayed in order to petition the Patent Office for the revocation of the patent if the latter be not more than five years old, and the case will be heard by the annulment department of the Patent Office, which has power, after hearing both sides, to annul the whole or any part of the patent and decree costs to either party. If the petitioner be abroad, he may be called on to deposit security for these costs before being heard. If a patent under this law be on the rolls for five years it is no longer attackable.

Working.-If the patentee refuses to grant a license, provided the granting of such license is in the public interest, and the would-be licensee is prepared to offer a fair price and security, then a compulsory license can be obtained. If the invention be only or chiefly worked abroad-that is, outside the German 
territory-the patent can be revoked at the discretion of the court. Making efforts to introduce the invention and being prepared to supply the demand may be deemed sufficient, and if there be no demand, and the inventor tries to create that demand and fails, the patent need not be worked till a demand springs up.

The declaration of the court in Wyngaert $v$. Wegmann, I884, is instructive, where Wegmann manufactured the porcelain rollers of his mill in Switzerland, supplying them for mills manufactured in Germany, and Wyngaert sought to have the claim for the porcelain rollers made void. It is as follows: "As the defendant has not manufactured the patented rollers within three years in Germany, this court has the power to annul the patent, but it does not find any occasion to make use of its power, chiefly on account of the great advantages which have been conferred upon the German milling trade through the introduction of F. Wegmann's porcelain rollers. As a rule, a patent should be declared null and void if not manufactured within the legal term. In this case, the chief weight of the national economical importance of the machine is not attached to its manufacture, but to its use, and, moreover, the legal requirements of the patent have been satisfied in Claim I.," which was for the machinery or mill in which the porcelain rollers were used.

In another case our representative interviewed one Dr. G-, one of the largest manufacturers of the kind of goods to which the patent related, with a view to get him to take up a patented invention on royalty. He declined. No working was effected for several years, when Dr. G_— brought an action for revocation on the ground of non-working. The court decided against him with costs, and the patent was sustained.

On the other hand, in a case where 3,000 of the patented articles had been made in the country and 300,000 imported during the same period, and the 3,000 turned out to be the simpler variety, while the more complicated variety made abroad was forbidden to the German licensee, the patent was declared void for want of sufficient working.

Where a part only of the invention has been duly worked, the rights to the unworked part may be declared forfeited. In other cases offers to grant licenses (the inventor not importing articles in accordance with the invention) were held a sufficient working, though no working really took place.

By recent treaties Italian, Swiss, and United States inventors having business establishments in their own country and in Germany are held to fulfil the law if they work their invention in their own country only.

Protection of Useful Designs.-These are granted for new or improved tools, or instruments and improvements in the form of usual devices or of parts thereof, but cannot be made to cover 
processes, or abstract ideas, or principles. There is no examination as to novelty, and no oppositions to grant are allowed, and where an application for a full German patent of invention for an arrangement of machinery or involving form is likely to be refused, it is a very common and useful resource to apply for a design protection. This protection, however, if the invention be old, can be upset in a court of law. Duration, three years, renewable for three years more.

These design patents are becoming very popular in Germany ; about 750,000 have been already issued. Beside these " $\mathrm{Ge}$ brauchsmusters," ornamental designs, or " Musterschutz," can be obtained for five years, renewable for ten more for new patterns such as woven designs, panels, handles of umbrellas, forms of chess-men, or the like. The cost of these is the same as for useful designs.

Actions for infringements of these patents are cheap, and the court can award either a punishment or a fine not exceeding 5,000 marks, or an imprisonment of not exceeding one year, and the publication of the particulars of the action and the sentence of the court at the expense of the infringer. Or, in addition to the above penalty, on the application of the patentee, it can decree damages not exceeding I0,000 marks, for which all the infringers-if there be more than one-are jointly liable.

Illegal Marking.--Any one marking goods or providing objects (or the packing of the same) with any marking indicating that the objects are patented, or even in his advertisements, business cards, or paper, using words or marks falsely indicating or likely to induce the belief that a thing is patented when it is not, is liable to a fine of I,000 marks.

Publication.-German patents are granted irrespective of the duration of foreign patents. Printed copies of his own patent specifications and drawings can be obtained by a patentee soon after grant at almost cost price.

In December, I9I3, the number of patents of invention or addition issued since the opening of the Patent Office of Berlin, July, I877, had reached 280,000 , and nearly three times as many more had been applied for and refused. The Author's firm has, however, obtained about 80 per cent. of all its applications, probably through carefully weeding out unlikely cases, and framing the German applications specially for Germany, instead of following the usual practice with too many patent agents of using the same draft specification for every country.

About 45,000 applications for patents and 56,000 for useful designs are made per annum.

Taxes.-Patents of invention are subject on pain of forfeiture to an annual tax increasing each year.

Patents of addition are granted free of further taxes, terminating with the term of the principal patent; but if the principal 
patent be annulled by a court, the taxes are payable instead on the patent of addition on the day on which they would have to have been paid on the original patent. In this case the date of the patent of addition determines the amount of tax, the period between the date of the patent of addition and the next tax day being considered the first patent year of the patent of addition. The patent terminates at the end of the fifteen years' term of the original patent. The annual taxes can be paid at any time in advance, and, if the patent be officially terminated before they come due, the taxes already paid but still undue will be returned. The taxes can be paid without fine up to six weeks after falling due or within twelve weeks of the date of the taxes becoming due-with an additional fine.

Useful designs can be registered for three years and renewed for three more. Ornamental designs for five years, renewable for five years, and again for another five. Trade marks are also registrable.

\section{GIBRALTAR.}

Population of Town, 20,000.

Population of Garrison, 6,000.

The Governor can, by ordinance, on the fulfilment of the requisite formalities, extend the scope of a British patent to Gibraltar, subject to the Crown or its officers having use or license of it on such terms as the Chief Justice sees fit.

\section{GILBERT AND ELLICE ISLANDS.}

(Ordinance No. 3, IgI6.)

English patents can be registered in these Islands so as to be operative therein as long as the British patent remains in force.

\section{GOLD COAST AND ASHANTI.}

(Ordinance No. I8, 3 I August, I9I6.)

Population, white, about 3,000.

" coloured, about I,500,000.

The law is the same as Nigeria (which see), except that there are no taxes after grant except a small one on any extension which may be granted. Trade marks are registrable.

\section{GREECE.}

Population, 6,000,000.

A special Act of Legislature is required to obtain a patent. Very few are applied for. Greece has now joined the Union for the Protection of Industrial Property. Trade marks are registrable. 


\section{GRENADA AND THE GRENADINES.}

(Ordinance No. 4 of I6 May, I898.)

Population, 73,000.

The patent law is very similar to the British, but altered so as to substitute colonial officials and institutions for British. An assignee may apply for a patent.

Annual taxes begin at the end of the fourth year.

\section{GUATEMALA.}

(Constitution, Art. 20.)

Population, 2,400,000.

Patents of from five to fifteen years and patents of addition to expire with the original patent are granted only to inventors resident in the country. Subjects or citizens of countries with which Guatemala has at the time a convention, and who have obtained patents in their own country, can obtain a Guatemalan patent of importation to expire with the original one, but in no case to exceed fifteen years' duration.

"Special concessions" (monopolies for trades not at work in the realm) can only be obtained by persons resident in the country, and must be applied for personally.

Models or specimens are required where the case admits of it.

Working must be commenced in the realm within a year of the grant of the patent, and must not be discontinued for a complete period of twelve months on pain of forfeiture.

It is a criminal offence to knowingly infringe a patent.

Special concessions are also granted by the Executive with the sanction of the Legislature, and, for a limited period, to any one establishing a new industry, which, though not worked previously in Guatemala, is well known abroad, or known only by mere publications, or the sale of the produce thereof, in the realm. These concessions may include exemption from taxation, exemption of the concessionnaire and his employees from military service, grant of public land for works purposes, and in some cases money grants.

There are annual taxes. Trade maiks are registrable.

\section{GUIANA.}

See "British Guiana," French Guiana is covered by a French patent. Dutch Guiana is covered by the Dutch law. See " Netherlands."

\section{HAWAII.}

This is now a part of the United States, and comes under the United States law. The few patents granted by the late Government are, however, unaffected by the change. 


\title{
HAYTI.
}

\author{
Population, 2,000,000.
}

A patent can be obtained by a special Act of Legislature.

\section{HOLLAND.}

(See Netherlands, page II6.)

\section{HONDURAS (BRITISH).}

(Latest Patent Law-Consolidated laws, Chap. 74.)

Population, 40,000.

The law is very similar to the British, but there is no compulsory licensing, and the costs and procedure are different. The patent falls with the earliest prior foreign patent falling void; and the patent is subject to a tax at the end of the third and seventh years.

\section{HONDURAS REPUBLIC.}

(Civil Code, 3I December, I898.)

Population, 650,000.

A patent of any foreign country can be extended to Honduras for the duration of such foreign patent, if the invention be not in use there by independent parties. The cost is decided specially in each case according to the presumed importance of the patent. There is an annual tax of five to fifty pesos gold, depending on the estimated value put upon the patent by the officials.

\section{HONG KONG AND KOWLOON.}

(Ordinances 2 of I892, and 22 of I3 August, I909.)

Population, 467,000.

Patents granted for duration of corresponding British patent if the invention be not already in use in the colony. The law is very similar to the British, but there are no revocation clauses for not working the invention within a given period and no annual taxes. Trade marks can be registered.

\section{HUNGARY.}

(Law of 7 July, I895, to No. II, I9II.)

Population, I2,000,000.

Note.-For questions relating to the effect of the late war, see note at head of article headed "Germany," which holds good for Hungary.

Kind of Patents.-There are two kinds of patents: patents of invention, for fifteen years, and patents of addition, to expire with the original patent. 
Who can Patent.-The inventor, his heirs and successors (assigns) can validly obtain a patent, and no one else.

What can be Patented.-Any new invention capable of being used industrially can be patented, except medicines, food for men and animals, and chemical products, and, if the Government opposes, warlike inventions. A process for making any of these can, however, be patented, and the process covers the article actually made by that process; but others have a right of making the same article by a different process.

Novelty.-An invention is new only so long as it has not been published in print anywhere, or publicly worked or patented by others in the realm. Official publications in a foreign state, granting reciprocity on this point to Hungary, may (by treaty with that state) not entail invalidity to a patent afterwards applied for.

Hungary has joined the Union for the Protection of Industrial Property, and the rules of the Union as regards protection by prior application in the Union hold good (see page 22).

Government employees cannot obtain patents for invention made through the knowledge obtained in their Government employment, provided that the Government opposes the grant.

Patents obtained by fraud of the true and first inventor can be opposed by the latter, and if he be successful he can obtain a patent for himself for the invention.

Patents of Addition, for improvements on prior patents, can be obtained within the first year of such prior patents by the owners of such prior patents; but if others apply to patent said improvements as patents of addition on such patents during the year, their applications are kept secret till the end of the year, and then granted if the owners of the original patents have not, during the year, made an application for the same. Patents of addition are subject to no annual tax so long as the original patent is kept up, but expire when the annual taxes on the original patent cease to be duly paid, or, in any case, on the expiration of the term of grant of the original patent.

Rights conferred by Patents are practically the same as those in England or the United States ; but any person who has begun to work the invention, or who has erected plant to work it in the realm before the date of the patent, can continue to work it in his own works, in defiance of the patentee.

Government Rights. - The Government can compulsorily take possession of a part or the whole of a patent, and compensate the owner.

Working.-If a patent be not worked in the realm within three years from date of grant sufficiently to supply the demand, and the inventor refuse licenses on just terms, especially after three years from the grant, and after due admonition by the Patent Office, the patent can be annulled. 
Annulling Patents.-Beside the clause set forth in the last paragraph, patents can be annulled in whole or in part if it be proved that they ought not to have been granted for any legal reason, or if the specification be insufficient or ambiguous, or the claims not novel or patentable.

Procedure.-Patent applications are examined as to whether they are in order, or whether they are in conflict with others applied for or granted within the preceding twelve months, but not otherwise as to the novelty. There is an appeal for three months from decision from the examiners to the Government, and from it again to the courts.

If allowed, the application is published at once or after a delay of not exceeding six months, at the option of the applicant.

Oppositions.-During the next ensuing two months after the patent is allowed and published, any one is at liberty to oppose the grant on the following grounds-either that the invention was not patentable or novel, or that the specification is not sufficiently exact or complete, or that the invention does not lawfully belong to the applicant, but had been wrongfully obtained, to the injury of the opponent's rights. Both parties in such case are heard before the judicial section of the Patent Office. No costs are allowed, but the court fees are apportioned against the parties, at the discretion of the Patent Office.

Amendments can be made at small cost before grant, and disclaimers of parts of an invention, or the entire renunciation of a patent, can be made at any time.

Joint Inventors are tenants in common, and each can work the invention or sell his share independently of the other-all parties, however, have to join in a license to a third party for such license to be valid.

Infringement.-The law is very severe against infringements, and is easily and cheaply put in force. Persons apprehensive of an action for infringement can get a prior judgment from the Patent Office as to whether the article they are making be an infringement of any given patent. About 5,500 patents were applied for annually before the war; and about 3,500 issued,

Annual Taxes, gradually increasing, have to be paid on pain of forfeiture. Thirty days' grace, without fine, for paying these, and thirty days additional on payment of a small fine.

Protection is granted for a model or design for three years, provided it be unpublished at the date of registration and be worked in the realm within one year. Trade marks can be registered.

\section{HYDERABAD.}

(Act No. Io of r309, Fasli (Mahomedan era).)

Population, I3,500,000.

This state grants patents to the inventor or assignee for four- 
teen years, which can sometimes be extended. These are independent of India. There are taxes at the end of the fourth and subsequent years.

\section{ICELAND.}

Population, 76,00o.

Patents are granted in Denmark which will cover Iceland if special application be made to the Ministry of Iceland in Denmark. There is a separate trade mark law for Iceland, which gives the benefit of the Convention for the Protection of Industrial Property.

\section{INDIA (BRITISH).}

(Acts 2 of I9rr, 4 of rgr5, and 5 September, I9r9.)

Including Burmah and British Baluchistan and the Shan States.

Population about $355,000,000$ (not including the $70,000,000$ in Native States.)

Mysore, Hyderabad, Travancore, and Jodhpur (Marwar) have patent laws of their own (which see).

On January I, I9I2, all patent applications came under a law which in nearly all respects is the British law, Indian officers and courts being substituted for English ones, except the following: First, there is no provisional protection, but the application is complete at start. Secondly, the hardships of the English working clauses are alleviated in that they only come into force if the applicant for revoking the patent is prepared and is in a position to manufacture or carry on the patented article or process in British India, and it is proved that the patentee refuses to grant a license on reasonable terms to him.

With regard to novelty the invention must not have been publicly used or known in any part of British India before the date of application, and the inventor must not have by secret or experimental use made direct or indirect profits from his invention in excess of such an amount as the Court or the Governor-General in Council, as the case may be, may, after hearing the matter and taking into consideration all the circumstances of the case, deem reasonable. Lastly, India is not under the Convention.

A patent can sometimes be extended, in which case annual taxes (which commence at the end of the fourth year) must also be paid during the extension.

Designs can be registered for five years, renewable.

\section{IRELAND AND THE ISLE OF MAN.}

These are covered by the British patent. 


\section{ITALY.}

(Act of 3 I Jan., I864 (Sardinian law, 30 Oct., I859).) Population, 37,600,000.

Kinds and Duration of Patents.-Patents of invention are granted for any term up to fifteen years, and if for shorter term can be extended on paying a somewhat heavy renewal fee and proportional taxes. Patents of importation for an invention patented and known abroad, but not yet at work in the realm, are granted to expire with the prior foreign patent for the same invention having the longest term, but their maximum duration is fifteen years.

Patents for addition are granted as in France and Belgium, free of annual tax, but expiring with the original patent. During the first six months, none but the proprietor of the patent can apply for certificates of improvements on his patent; and during this period he can also enter disclaimers, or, as is technically described, "obtain certificates of reduction."

What can be Patented.-An invention patentable in Great Britain or the United States is patentable in Italy, except that medicines are unpatentable.

Only a single invention can be included in one patent.

Who can Patent. - The inventor or his assigns, and practically any person, firm, or company, if the original inventor does not object.

Novelty.-A patent is void if the invention have been fully published or worked in the realm prior to protection by application for the patent, or by rights under the Convention for the Protection of Industrial Property (see page 22), with these exceptions-Ist, if the patent be applied for as a patent of importation to expire with a given foreign patent for the same invention, then the prior publication abroad in Government publications will not invalidate the patent ; 2nd, the Government have the right of allowing inventions to be publicly shown in given international and other exhibitions certified by Government and such exhibiting to be equivalent to provisional protection for the invention for twelve months from the opening of the said exhibition, except where the country in which the exhibition is situate allows only a less period of protection, when that lesser period will be the period allowed in Italy.

Procedure.-There is practically no examination, but all patents are granted if in order. Appeals to a Commission can be made where the patent is refused on the ground that more than one invention is claimed-and in patents of addition where they are refused on the ground that the subject-matter is not sufficiently connected with the original invention.

Rights conferred by Patent are similar to those in Great Britain, but there is no compulsory license clause. 
Priority.-Protection dates from the application, the term of the patent from the last day of March, June, September, or December next following the date of application.

Renewals.-Applications can be made for a less number of years than fifteen, and the patent thus obtained can, at any time before the expiration of its term, be renewed for a further period not exceeding fifteen years from the date of the original patent. As there are special fees for prolongation, in addition to the difference between the first cost of a patent for the original and for the extended term, prolongation should be applied for as seldom as possible. The usual plan is to secure a patent for at least six years, and at the expiration of that period have it prolonged for the full term of the fifteen years allowable. A patent cannot be prolonged without the original document being produced.

Working.-A certificate must be obtained that the patent has been worked within the realm within one year of grant, in the case of patents granted for less than six years, and within the space of two years in the case of patents of longer duration, or three years in the case of patents obtained under the rules of the Union for the Protection of Industrial Property, and the working must not be intermitted for two years continuously, otherwise the patent may be declared void. Exhibiting in a certified national or international exhibition is equivalent to working, and importation of the patented machine in some instances has been held sufficient, as the main benefit was derived from the working; not the making, of it. On the other hand, the courts, especially of southern Italy, are very rigorous in requiring genuine working, especially where there is any " dog in the manger practice," and it is always best to commence the working six months before the last day, especially if working is to be by advertisement.

Further, in the case of German subjects and United States and Swiss citizens, it is sufficient for the inventor to prove the working in their own country if they also have business establishments in Italy.

Taxes.-There are two kinds of taxes on patents-the " proportional tax," varying with the duration required, paid on applying for the patent or prolongation, and included in the cost of same, and an " annual tax," payable on the last day of March, June, September, or December next ensuing after the anniversary of the date of application for the patent.

Payment of taxes and formalities omitted during the war can be made good any time before December 3I, I920, but without prejudice to rights of third parties.

About 8,000 patents are now granted yearly.

Design patents are granted for two years only.

Trade marks are registrable. 


\section{JAMAICA.}

\section{With Turks and Caicos Islands.}

\section{(Act 30 of 1857 , Patents, Law I5 of I89I and Amendment of Igor.) \\ Population, 850,000.}

Patents are granted for fourteen, and if considered expedient, twenty-one years, but limited by the duration of any prior foreign patent for the same invention, to the true and first inventor, or his assigns, of an invention not hitherto known or used in the islands. There is no rigid examination, but it is handed to an expert, who can be interviewed by our agent and can charge any fees up to five pounds. A patent obtained by fraud, and the consequent publication of the invention, does not invalidate a patent afterwards obtained by the true and first inventor. Disclaimers can be made, and patents of addition, to expire with the original patent, can be obtained by the original patentee, to form a part of the original patent. The penalty for infringing is three times the actual damage as estimated by the jury of the court, and costs and injunction.

Trade marks can be registered.

\section{JAPAN AND DEPENDENCIES (including KOREA).}

(Law 23 of 2 April, I909, and Ordinance, IgI2.)

Population, 67,000,000.

Kind and Duration of Patents.-Patents of invention are granted for fifteen years from date of registration, for inventions not known in the Empire or set forth in a printed book circulated or distributed therein, except descriptions of experiments on the invention made not more than two years previously. Patents for improvements on a patented invention are granted to the owner of the original patent, to expire with the latter; but this can be changed to an independent patent if the grant of the original patent be refused or annulled.

Who can Patent.-Only the true and first inventor or discoverer, they being Japanese or citizens of countries having commercial treaties with Japan (or their assigns), can obtain a patent of invention, and only the owner of the original patent can secure a patent of improvement, but where a man is directly employed to perfect an invention the employer is held to be the inventor of any invention he may make thereon. No official of the Patent Office can own a patent unless he owned it before entering the Government employ or received it by bequest.

An inventor outside the realm, if a citizen of a country having treaty relations with Japan, can obtain a patent, but must appoint 
an agent domiciled in the realm as his agent, and such agent must be satisfactory to the Government and a registered patent agent in the country. Our agent fulfils these conditions and acts for our clients.

What can be Patented.-Almost any new thing that can be patented in the United States or Great Britain can be patented in Japan, except articles of food, drink, or luxury, medicines and methods of compounding them, things regarded as contrary to public order or morality, and things which have been known to the public or have been in public use before the application for the patent; but this latter rule does not apply to things which have been known to the public for the purpose of trial for not more than two years, and this rule is also subject to the regulations of the Union for the Protection of Industrial Property. A process and application or apparatus cannot be covered in one application.

At present the office are very apt to reject inventions which they consider closely resemble in appearance others known, and they frequently reject an invention as " publicly known " without citing any specific proof.

Where a patent has been applied for or granted in fraud of the real inventor the latter can bring a suit of nullification; when, if successful, a patent is granted him dating as of the date of the nullified patent.

Mechanism similar to that patented, if actually in existence in the Empire at the date of the patent, can continue to be used by its owners in defiance of the patent. Mere experiment or research and making infringing articles solely therefor, is not a violation of the patentee's rights.

Exhibitions.-Exhibits in exhibitions organised by the central Government, or by the authorities of a prefecture, are, by notification to the Director of the Patent Bureau, duly given before entering the exhibit, provisionally protected without further charge for six months from the date of entry into the exhibition, and exhibits in an international exhibition in any of the states of the Union for the Protection of Industrial Property are provisionally protected for the same period in Japan and to the same extent as they are protected (in consequence of exhibiting and notification thereof) in the country in which the exhibition is situated.

Military and Naval Patents and others required in the public interest can be expropriated and compensation paid for same by the Treasury, the patentee having an appeal to a court if not satisfied with the compensation.

Examination.-Applications are examined to see if they be in order or previously published by the inventor, and to a certain extent by others, in any country prior to the application, or if they interfere with any other pending application. If the 
examiner reports against the patent the report is submitted to the parties interested and the patentee can demand a reexamination, and if the decision of the first examination be upheld appeal can be lodged within sixty days to the Patent Bureau, and from the Bureau to the Supreme Court also within sixty days. If an interference between two pending applications be declared, or if applicant be opposed, both parties are called upon to furnish full statement of their respective cases, and if the decision finally come to be that the second applicant is the first inventor, and the first patent or patent application be cancelled, the second applicant can have his patent dated back to the date of the cancelled patent. Appeals can be made from decisions of the Patent Court to the Supreme Court.

An inventor making an invention or an improvement on a patented invention which he cannot use without infringing a prior patent can apply to the prior patentee for a license, and if this be not granted on fair terms he can apply to the Minister of State for Agriculture for a compulsory license. Both parties are then heard, and the Minister has the right of granting such license on such royalty and security to the prior patentee as he may consider fair.

If an original patent be annulled the patents of addition, if any, are not annulled with it unless specially mentioned in the decision, but notice must be given within sixty days to the Patent Bureau of desire to continue the patents of addition by paying the taxes on the expired patent.

Amendments can be made, provided they do not extend the invention. Actions for infringement or revocation of patents are tried before three or five patent judges, who must give their reasons with the decision.

Working.-A patent can be annulled if the owner allows three years to elapse after grant without publicly working in the Empire. Advertising well for a licensee is not sufficient working, per se, but is considered as extenuating circumstances by the courts, and we know of no case where it has been tried and where the patent has been annulled without the patentee having another chance given him.

Marking.-All patented articles must be marked " Patented in Japan" (in English or Japanese). Penalties for wrongful marking or importing, using, or selling the patented article in contravention of the patentee's rights are major imprisonment of from fifteen days to three years, or a fine of from ten to five hundred yen and the confiscation of the infringing article, which is given to the patentee. If the patentee sends out patented articles not so marked he cannot get damages against an unwitting infringer.

About 7,500 patents are applied for each year, and about $I, 500$ issued. 
Taxes.-Annual taxes have to be paid, on pain of forfeiture of the patent. In case of accidental failure to pay the taxes before the actual cancellation takes place payment can be made within one year on payment of a small fine and proving the facts.

Annual taxes have to be paid on patents of invention on pain of forfeiture of the patent.

Designs can be protected for three years renewable for seven more. Trade marks can also be registered.

\section{JODHPUR (MARWAR).}

(Act of 7 August, r9o6 and No. I, I9I6.)

Patents are granted to the first inventor, or importer, his executors or assigns of new inventions, at the discretion of the Mahkma Khas, and when the period allowed will expire within a period of from one year to six months they can be again renewed at the discretion of the Mahkma Khas.

\section{JOHORE.}

(Enactment 3 of 3 May, I9II, and No. I, I9I5.)

Population, r8o,000.

Patents for fourteen years are granted to the inventor, first importer, or his assigns for inventions not at work or published in the British Empire or Johore more than six months prior to the date of application for patent. British or British colonial or Indian patents can be extended to Johore to expire with the rights in the country of origin, but the Sultan for good cause can refuse to grant such extension. Patents about to expire can sometimes be extended when of sufficient merit for another seven years.

Compulsory licenses can be obtained in the case of patents not worked in the realm.

There is a tax at the end of the seventh year, and if a patent be renewed on renewal.

\section{JUGO-SLAVIA.}

Population, II,500,000.

This state does not at present grant patents, but has joined the Union for the Protection of Industrial Property, and is expected to shortly have a patent law in operation.

A packet of new designs can be registered together for any number of years up to ten.

The protection falls void if not worked in the realm within one year, or if the registered articles are imported from abroad 
with the knowledge of the owner of the protection or his representatives.

Trade marks can be registered.

\section{LEEWARD ISLANDS.}

(Act No. 3 of 9 June, Igo6.)

Population, I30,000.

The law is almost a replica of the English one of 1883 .

Patents are granted for fourteen years (but limited by duration of any prior foreign patent) to first inventor, for any manufacture new as far as the colony is concerned, and not the subject of an expired patent abroad. There is no examination as to novelty. Trade marks are registrable.

\section{LIBERIA.}

\section{(Act of 23 December, I864.)}

Population, 2,000,000.

Patents are granted for fifteen years to the true and first inventor, or his assigns, for inventions not yet known or used within the limits of the Republic. They must be worked within the first three years of their duration in the Republic, on pain of being considered abandoned.

\section{LU XEMBURG.}

$$
\begin{aligned}
& \text { (Law of } 30 \text { June, I880.) } \\
& \text { Population, 260,000. }
\end{aligned}
$$

The patent law is in most respects identical with the Belgian, except that an invention must be new, not merely in Luxemburg, but in the entire Customs Union of Germany, to be validly patentable. By new is meant not described in public print or publicly worked. So also a patent is invalid unless before, or within three months after, its application a patent for the same invention be applied for in Germany and (afterwards) granted. A patent is granted for fifteen years, but only remains valid as long as the German patent for the same invention is kept up. If, however, the German patent be declared void for want of working, the Luxemburg Government can continue the Grand Ducal patent. Working in the Duchy must be proved within three years of grant, but this clause is very liberally interpreted. Compulsory licenses can be obtained at rates fixed by Government, by parties wishing to use an invention patented more than three years previously-if in the opinion of the Government such compulsory licenses are desirable. It is generally useful to protect an invention in Luxemburg when patents are obtained in the surrounding states of Belgium, France, and Germany; it being very difficult to prevent importation into France and Belgium, 
an infringer in Luxemburg can be a veritable thorn in the side to the owners of the German, French, and Belgian patents, unless he can be brought to account in Luxemburg itself through a Grand Ducal patent. The law is very severe against wilful infringers, and is easily put into execution. About 250 patents are granted yearly.

Annual taxes as in Belgium.

Trade marks can be registered.

\section{MALAY STATES (FEDERATED).}

(Law No. I9 of Io December, I9I4.)

Population about $I, 000,000$.

The Confederation consists of the four states of Perak, Selangor, Negri-Sembilan, and Pahang, each of which had a separate patent law, and granted provincial patents. By the law of I9I4, these separate laws were repealed, without prejudice to patents already granted. Patents for fourteen years are granted to the first inventor or importer of an invention in the realm provided the latter be not published or generally known or in use in any part of the British Empire or its dependencies before the application for a patent by the applicant or person through whom he claims. Six months' provisional protection, followed by complete, is granted almost exactly as in Great Britain prior to I920, and the law as regards applications is practically a copy of the British. Patents granted in any other part of the Empire can be extended to the Malay States, to fall with the rights in the country for which the original patent was granted, subject to examination and advertisement for opposition by rival claimants.

The costs, and patent law generally, are copied from the British law, except that the initial fees are rather more, and in place of annual taxes there is a single tax at the end of seven years of $\$ 50$.

A Malay States' patent can, at any time, be registered in the states of Kedah and Kelantan, and will then cover these states also, but without prejudice to rights of third parties existing at time of registration. Johore has an independent patent law (which see).

\section{MALTA.}

(Ordinances No. II of I899 and 7 of I907.).

Population, 224,000.

The patent law is substantially identical with the British, but with a few slight improvements. Malta has joined the Union for the Protection of Industrial Property.

Annual taxes the same as in Great Britain.

Designs and trade marks can be registered. 


\section{MAURITIUS AND ITS DEPENDENCIES.}

(Ordinance No. 16 of 1875. )

Population, 378,000 .

Patents are granted to the original inventor or his assigns for twenty years. This period can be prolonged by the Governor on showing a good case nine months before its expiration. There is no examination as to novelty, but publication is made before grant, after which it is open to opposition for a limited period; but oppositions are very rare. The invention must not have been published (except in Government publications), or be in use in the colony or the United Kingdom, or be patented more than a year in Great Britain, prior to an application for a patent in the colony. The public use, however, for not exceeding one year by the patentee or his assigns, licensees, or representatives, prior to patenting, is by a special clause in the Act held not to invalidate the patent. There are no annual taxes or compulsory working clauses.

\section{MEXICO.}

(Law of I October, I903.)

Population, $\mathrm{x} 5,000,000$.

Who can Patent.--The actual inventor, his agent, or legal representative can obtain a patent.

Duration, twenty years from day of issue; but patents for inventions first patented abroad expire with the first patent issued to the applicant. Patents of extraordinary merit are sometimes prolonged for a further five years beyond the twenty.

What can be Patented.-Almost any new invention that can be validly patented in Great Britain or the United States can be secured by patent in Mexico, with the exception of new chemical products; but new processes or plant for obtaining such products and new industrial applications thereof can be protected.

Novelty.-By " new" is understood not published in print or worked industrially in any country before the date of the application for the patent, or protection under the Convention or special protection in an international exhibition as hereafter mentioned.

The publication of a foreign patent less than three months before the date of application in Mexico does not affect the validity of the Mexican patent.

Mexico has joined the Union for the Protection of Industrial Property.

Exhibition in an officially recognised exhibition is not fatal 
to a subsequent application for a patent, if before exhibiting the applicant files the necessary notice at the Patent Office of his intending so to exhibit, and provided the patent be formally applied for within three months of the final closure of such exhibition.

Rights conferred by Patent are similar to those in Great Britain and the United States, except that actual manufacture of infringing products is a criminal offence, so is importing, dealing in, using for commercial purpose, or being possessed of the patented invention after due warning; with these exceptions, a man may import, make, or use any invention for experiment or research, and if before the date of first protection an independent party has worked or made the necessary arrangements for working the invention, he can go on working in defiance of the patent.

Examination.-There is no examination as to novelty, but all applications are granted, if in order and for a proper subjectmatter, without guarantee for novelty or validity.

Any decision of the examiners refusing an application as not in order can be appealed against to the courts.

Extension.-A patent may be further extended at the option of the Government on such terms as the latter may decide, but proof must be produced that it has been for the last two years immediately preceding in industrial use in the realm.

Working and Compulsory Licenses.-If after three years from the date of first protection the invention be not industrially at work in the country, or if, after that period, industrial working be suspended for three months, the Patent Office can grant other parties a license to work the invention, they paying half the profits to the patentee. Incorrect returns to the patentee are punishable by a heavy fine, imprisonment of from one to twelve months, and the licensee is also liable to the patentee for damage and loss.

The patentee has the right of getting a license granted by the Patent Office annulled any time two years or more after the grant on proving that he has himself established industrial working of the invention, or any time on proving that for two consecutive years, or three years in the case of Convention patents, the licensee has not worked the invention. Both the owner of the patent and one who has obtained a license through the Patent Office must, within fifteen days of first starting industrial working, prove such working to the Patent Office.

The working clause is practically a dead letter.

Official Examination as to Novelty.-Any interested party can at reasonable cost get the Government to officially examine into and report on the novelty of a patent, but the Government does not in any way guarantee this report.

Government Expropriation.-The Government can on payment of reasonable indemnity (ascertained, if an agreement 
cannot be come to, in accordance with the rules in force for the expropriation of real estate) take a patent or a patented invention for Government or public use. This refers mainly to patents for munitions of war.

Nullification.-A patent can be annulled by the courts if it be proved that (I) it has been granted wrongly ; (2) that the claim or the description of the drawing is not sufficiently clear or precise or the whole insufficient to enable the invention to be worked therefrom; (3) that the object patented is not in accordance with the title ; or (4) that the invention has previously been patented at home or abroad (subject to Convention, see page 22).

Infringements of Patents by actual manufacture are both civil and criminal offences, punishable by a fine of from 500 to 2,000 pesos and imprisonment of from one to three years.

The mere unauthorised use, the sale or circulation or importation of the patented article, or hindering the patentee in the exercise of his rights, are also criminal offences and heavily punished, while in case of a second or third offence, even with a different patent, the punishment is increased. The infringer in all cases is liable to pay costs and damages to the patentee, and to the confiscation of the infringing articles. About I,200 patents issued annually.

Mexico is a great mining and petroleum country.

Marking Goods "Patent."-Any one marking an article as "patent" when it is not is liable to a fine of from 50 to $r, 000$ pesos or imprisonment of from one to eleven months, or both.

Industrial Designs can be registered for ten years. Trade marks can also be registered.

A recent revolutionary government required patentees of all existing patents to pay all the fees over again. A second equally fugitive government cancelled this order, and a third military government revived said edict on pain of forfeiture of the patents.

\section{MOROCCO.}

(Decree of 23 June, rgr6.)

Population, 5,000,000.

\section{FRENCH ZONE.}

The patent law is very similar to the French, enabling subjects of all the states of the Union for the Protection of Industrial Property (see page 22) to take out patents for inventions, having all the advantages of the Union if applied for in Morocco within one year of the original patent abroad. Infringement is both a civil and criminal offence, and suits for infringement or other patent matters are tried before French courts. 


\section{The Rest Of Morocco.}

Infringement of an English patent or trade mark in Morocco by a British subject can be proceeded against in the Consular Court, and damages obtained.

Infringements of trade marks, other than by Moorish authorities, can be proceeded against in the Moorish courts or the Consular courts in Morocco, of Austria, the United States, Belgium, England, France, Germany, Italy, the Netherlands, Portugal, and Spain, provided that the trade mark be registered in the country of the respective foreign consular court.

\section{MYSORE.}

(Regulation No. XI of 26 November, I894.)

Population about $5,800,000$.

The actual inventor, his executor or assign can patent an invention for fourteen years from date of application. The invention must be new (unpublished) at the time in Mysore, British India, and the United Kingdom. But use or publication within one year prior to application and after application in the United Kingdom by the inventor or his agents is not held to invalidate a patent. But a Mysore patent falls with the expiration of an Indian or British patent for the same invention. A person can bring an action to show that a patent was wrongfully granted, but cannot defend an action for infringement on any other ground than that he has not infringed, or that he himself or some person through whom he claims is the true and first inventor, or that the patent has expired. Applications can be amended if incorrectly describing the invention. Compulsory working or the granting of licenses can be ordered by a court if the invention be not at work in Mysore. Under some circumstances a patent can be extended at the end of fourteen years.

Annual taxes have to be paid before the end of each year from and including the fourth.

Designs can be registered for five years, and renewed for two further periods of five years each (latter optional with Government).

NATAL.

(See South Africa.)

\section{NETHERLANDS (HOLLAND) AND DUTCH COLONIES.}

(Act of 7 November, IgIo.)

Population-Home, 6,800,000; Colonies, 47,000,000.

Variety and Duration of Patents.-Holland being a member of the Union for the Protection of Industrial Property (see page 22), 
patents are granted under the Convention for one year from the date of the first patenting in any other country of the Union, to date from the date of application for the first patent applied for under the Convention, otherwise they are only granted for inventions new at the date of the patent. The duration of such patents is fifteen years.

Patents cover not merely Holland, but its East and West Indian colonies.

Patents of Addition are issued to the actual owner of any patent (or application), for improvements on the invention set forth in such patent or application. These patents of addition expire with the original patent, but are not subject to annual taxes.

If, however, the original patent be declared void during the period for which it was granted, the patents of addition are treated as original patents and can be kept in force by paying taxes on them as if they were dated with the date of the original patent.

Novelty.-The word "new" means not in use or published in any country sufficient for an expert to be able to manufacture therefrom. The showing of an invention, however, in an international exhibition is not considered a publication provided the patent be applied for within six months of the opening of such exhibition. Any person or set of persons, or a company, one of them being the inventor, can obtain a patent, but the first applicant, except in the case of Convention patents, is considered to be the original inventor unless it is proved that he has taken the invention illegally from another person. Where two or more apply for a given invention independently on the same day no patent will be granted until it be proved which one of them is the real first inventor. Where a person is employed by another specially to work out an invention, the employer is held to be entitled to the patent. Even where an employee independently invents an improvement on the process or apparatus on which he is employed without being asked to make experiments the employer is alone entitled to this patent, but he can be compelled to compensate the inventor, and if the two cannot agree on the compensation, the Patent Office or a regular judge decides the question. If, however, the inventor makes no claim during the first three years of the duration of the patent, his right ceases.

If a patent be applied for under the Convention in Holland or in a Dutch colony during the priority allowed and before the actual application in Holland by the inventor, the right to use the patent may be granted by a court to such person unless he has taken it illegally from the inventor.

Procedure.-A patent being applied for, it is examined to see if it be in order with regard to all questions touching the validity 
(a search as to novelty being included). From the decision of the examiner refusing to lay the application out for public inspection an appeal within one month can be made to the Patent Office. If the patent be eventually laid out for public inspection, opposition can be entered during the ensuing six months by any interested party to the grant of such patent. The opposition is heard by the Department of the Patent Office to which the examination was entrusted. Said department will for itself, during the said period of six months, examine the application and may institute a further search in respect of novelty. The department will decide after hearing all the parties concerned as to the grant of the patent. From that decision there is an appeal within three months to the Patent Office, which after consideration and hearing all the parties concerned shall give a decision, from which there is no appeal. From this it will be seen that the Patent Office is " a law unto itself," and there are complaints of high-handedness. If allowed, the patent is dated the day after allowance or final decision.

All patented articles must be marked "Octrooi Nederlandsch No. _ , " or if they cannot be marked owing to the nature of the article, the package in which the article is sold must be so marked. Omission to so mark is a criminal offence, as is also inserting such mark without proper justification or falsely using the word " patent," or any word implying that the invention is protected, in connection with the article. The penalty in each case is fine or imprisonment.

Any eligible applicant can, after three years from the date of the grant of the patent, obtain a compulsory license from the Patent Office at any time if the invention be not then at work within the realm on a reasonable scale in the opinion of the examining department of the Patent Office. An appeal from the decision of the examining department can be lodged within three months to the General Assembly of the Patent Office, whose decision is final.

Contracts for licenses are only good against third parties when they are registered at the Patent Office.

Patents must be worked in an industrial establishment in the realm within five years of the date of grant, in an effective or adequate manner, on pain of their being declared void by the Patent Office on the petition of any person unless really good grounds are shown for the omission to work them. The Government has the right of appropriating the patent at any time, paying a reasonable compensation therefor, and if in their opinion it is to the advantage of the state to do so.

Prior Use.-A person using the patented article privately in the realm or having made the necessary steps for that purpose before the date of application for the Dutch patent (even under the Convention) can continue to use it to the same extent as 
the patentee if he establish his right before the Patent Commission within six months after the laying open of the application to public inspection, but he cannot license or assign his rights to other parties except together with the commercial concern in which he used the invention. In such case the Patent Office will issue to him a certificate of prior use.

The Patent Office has branch subsidiary offices in all the three important Dutch colonies.

Infringements after the date of the publication of the application can be proceeded against after the patent has been allowed, and a writ issued on the infringer immediately after publication of the specification. Knowingly infringing a patent is a criminal offence entailing fine or imprisonment. On the second occasion the penalty is doubled. The judge can publish his decision, and the infringing articles are handed over to the patentee. The patentee can also obtain damages.

Mortgages, assignments and licenses must be registered before they can be effective against other parties, and an innocent third party registering an assignment, license or mortgage first holds the right against a prior mortgagee, assignee or licensee who is not on the register.

Annual Taxes.-Annual taxes have to be paid on the last day of the month on which the patent was dated. They can, however, be paid within one month or the subsequent two months of that date with extra fines.

Trade marks are registrable in Holland and in each of the three colonies (East Indies, Surinam, and Curaçoa), separately.

\section{NEWFOUNDLAND.}

(Consolidated Statutes, Title I2, Chapter I09 “Patents.")

Population, 300,000.

Duration of patent, fourteen years, but it is lawful for the Governor in Council to extend it for a further term of seven years. Patents are only granted to the actual inventor, his assignees, or legal representatives. A model must also be provided if the case admits of one, and specimens and ingredients if the invention be for a composition of matter; but in some cases these are dispensed with on the petition of the inventor.

The invention must not have been introduced into public or common use in the colony prior to the application, and it must be worked in Newfoundland within two years of the date of the patent, or it will be deemed to be forfeited. In cases where the invention has been previously patented in other countries, the duration is limited to that of the first foreign patent. It cannot be validly patented in Newfoundland after the expiration of a corresponding foreign patent. 
Notice of the intended application for a patent must be advertised in the Royal Gazette, and in another newspaper in the colony for at least four weeks before the formal application, and this notice must include a description in general terms of the invention.

The application is referred to the Attorney-General, who hears any opposition that may be entered, examines the case, and if he judges it to be a good and proper subject for a patent, and the application in order, he certifies the same, and the patent is issued by the Governor in Council. Re-issues are granted as in the United States, but at any date of the duration of the patent, and patents of addition can be obtained.

Penalty for infringing a patent is three times the actual damage sustained by the patentee, and is recoverable by action in any superior court of the island.

The inventions most in demand in Newfoundland are those for sea-fishing, fish-curing, and wood-pulp manufacture.

Trade marks are registrable.

\section{NEW ZEALAND.}

\section{(Act I7 of 28 October, IgII.)}

Population, I, I00,000.

Any one being the true and first inventor or his assignee, nominee, or, in case of death his legal representative (within six months of decease), can apply for and obtain a patent for fourteen years, alone or conjointly with others.

The law as to what is patentable is the same as the British. An invention can be provisionally protected for nine months, or by a complete specification at start as in England. The procedure is nearly identical, but, in addition to the usual grounds for opposition, want of novelty, and that the communicator is not the actual inventor or his legal representative or assignee can also be urged against the patent. If by accident or otherwise the inventor has omitted to apply for the sealing of his patent in time, he can, on petition and stating the exact circumstances under which application for sealing was neglected, be heard by the Registrar who can, if he considers the case a proper one, advertise it for opposition, hear any opposition, and seal the patent or dismiss the case. There is an appeal from the Registrar to the Supreme Court (Act 49 of I9I3, II December).

The law as regards amendments, compulsory licenses, exhibiting in authorised exhibitions, rights of the crown, actions for infringements, or use of patent on foreign ships, rights under the Convention for the Protection of Industrial Property, extension of term of patent and using illegal threats, is almost a copy of the British (colonial officials being substituted for British ones). The law as regards penalties for non-working 
or for working mainly abroad is not so severe as the British, as the patent after four years can be declared inoperative if worked mainly abroad, but the patentee has usually a time given to prove working; and even if declared inoperative it can be reinstated on the patentee proving he has now got to work satisfactorily in the colony-unless other independent parties in the meantime have begun working it in the realm. The court in place of declaring a patent inoperative can grant a compulsory license to the applicant on such terms as it sees fit. Any one illegally using the words " patent," " patented," or " Patent Office," etc., is liable to a fine not exceeding $f 20$. The patent is liable to a tax at the end of the third and of the sixth year on pain of forfeiture, but a delay of three months is allowed, in cases of accidental omission, on paying an additional tax. No one can practise as a Patent Agent without being first registered as such.

About 2,00o patents are applied for yearly.

Patents for small articles in large demand and other inventions not requiring a large capital are those most appreciated.

Taxes have to be paid before end of third and sixth year.

Three months' grace to pay tax with a fine in case of accident. Designs and trade marks are registrable.

\section{NICARAGUA.}

(Law of II October, I899.)

Population, 800,000 .

Patents for inventions not known in the realm are granted for five to ten years. There is an annual tax varying at the option of the Patent Office, payable on the Ist of January. Patents must be worked within one year on pain of forfeiture.

Monopolies for manufacturing a product not yet manufactured in the state are granted, the duration varying with the product.

The Government is, as a rule, rather uncertain, and the cost of patents and especially of monopolies correspondingly so.

\section{NIGERIA (including LAGOS).}

(Ordinance 30 of 13 July, I9I6.)

Population about $17,000,000$.

The inventor or owner by assignment, transmission or other operation of law of any invention or of the exclusive right thereto within Nigeria, can file a patent stating that he has been granted a patent in the United Kingdom for such invention and making application for a patent in Nigeria. The Governor, if he thinks it proper, can grant a patent for the same for Nigeria to expire with the British patent. Any other inventor, not having a 
British patent, can apply for provisional protection by a petition in which he agrees to apply within three months from the date of such petition for a grant of the patent in the United Kingdom, and if he do apply for the same and it is granted, in due course the Governor in Council may grant a patent for Nigeria to expire with the British patent.

There are taxes on Nigerian patents at the end of the fourth and eighth year. At the expiration of the grant the patentee can petition for an extension, which the Governor, if he sees proper, can grant for five years, or for fourteen years further, or such less time as he may think suitable.

Trade marks can be registered.

\section{NORTH BORNEO.}

(Proclamation II of I July, I908.)

Population, I75,000.

The original inventor, his heirs or executors, administrators or assigns or first importer can patent an invention. The invention must not have been in public use in the empire by parties unconnected with the inventor before the application in Borneo.

Period of exclusive privilege fourteen years.

English Patents can at the Governor's discretion be extended to cover North Borneo. There are no " working " or compulsory license clauses or annual taxes.

Otherwise the law is substantially similar to the British.

\section{NORWAY.}

(Law of 2 July, I9ro.)

Population, 2,600,000.

Kinds and Duration of Patents.-Patents of invention are granted for fifteen years, subject to an annual tax. Patents of improvement are granted for the term of the original patent, expiring with it, and are not subject to annual taxes; should, however, the original patent go void before the end of the fifteen years, the owner of the patent of addition can keep the latter in force by paying the taxes as they would have become due on the original patent.

Who can Patent.-The first inventor, or his duly authorised assignee or legal representative, alone can by law obtain a patent for invention. But any person, firm, or corporation may apply for a patent (and if the first applicant, and not opposed by the inventor or persons having rights under him), is held to be the rightful patentee.

If any one can prove that he has worked the invention in the 
realm or made arrangements for working it before the date of application for the patent, he can continue to use it in his own business only, and assign the business as a whole, including his right, to others.

This applies even to patents claiming priority under the Union for the Protection of Industrial Property.

What is Patentable.-All new inventions, useful in industry, and not contrary to law, morality, or public order, can be patented, except articles of food, beverages, medicines, and chemical substances. Methods of manufacturing these, and apparatus therefor, can, however, be secured.

Novelty.-By new is meant not known in the realm in such manner that persons skilled in the trade to which the invention relates could work it. The laying open of the patent specification by a patent Authority, and advertising it for opposition purposes at home or abroad, or by showing in an international exhibition, within six months prior to the application for the patent, however, is not to be considered fatal to novelty.

Norway has joined the Union for the Protection of Industrial Property, so inventions protected by citizens of any state of the Union in their state are protected for twelve months in Norway; the papers required to protect under the "Convention " can be supplied any time before publication of the invention. See, however, article headed "Who can Patent."

Rights conferred by Patents.-Patents confer substantially the same privileges in Norway that British and United States patents do in their respective countries, but if the patent be not at work at the end of three years from date, both public authorities and private firms can obtain compulsory licenses at fair rates, to be decided, if necessary, by arbitration. If, however, the rate be a sum down, that sum must be paid before the license is granted. If it be a royalty, the licensee is required to give sufficient security that he will duly and faithfully pay the instalments as they come due.

Procedure.-All applications for patents are decided upon by the first department of the Patent Commission, and an appeal from its decision can be had to the second department of the Patent Commission, from whom there is now no appeal. Until an application is actually accepted for advertisement it can be amended by applicant for a small charge. The applicant can on application have publication delayed for six months after it is so accepted. The rule as to only one invention being allowed in one application is as in Denmark.

A patent application is now advertised as open to inspection, and any one may, during the next following eight weeks, oppose the grant on the ground that it was not new at the date of application or that it had been taken from him or from a person who had assigned his rights to him. 
If opposed successfully on the second ground, the opposer can file an application himself for the patent within two months. Against the decision there is an appeal. Patents are issued about eight weeks after the opposition period has expired, and about six months afterwards are published in the Norsk Patentblad.

A non-resident patentee must appoint an agent to represent him, who shall be registered at the Patent Office. This agent is usually the correspondent of the patent agent through whom the application is made. If the agent dies or leaves the country, another must be appointed, or the patent will after due notice be declared void.

Rights of a Patentee.-A patentee has the sole right of making, selling, letting, or using the invention for a business purpose, or for profit, but there is nothing to prevent any one making or using the invention for a thoroughly scientific purpose, or for his own private domestic use, if not for pecuniary profit. Intentional infringement of a valid patent is a criminal offence, punishable by fine or imprisonment. Unintentional infringers are required to make good to the patentee all damages he may have sustained by their infringement, and to pay him all profits they have made by such infringement. The infringing articles are confiscated or kept in custody by the Government at the expense of the infringer until the termination of the patent, or by agreement they can be handed over to the patentee. The words "infringing articles" are held to cover any implements exclusively used in the infringement. In the case of a process of manufacturing a new species all similar substances are held to be infringements and made by the patented process, unless the contrary be proved.

If the defence be invalidity of the patent, the action for an infringement can be stopped till the infringer can bring a suit to have the patent declared void.

The patent specifications and drawings are printed as soon as the case is allowed by the examiners and final fee paid, but the patentee can obtain a postponement of publication for six months, and if the patent be refused on opposition the final fee is returned to the inventor.

Working and Compulsory Licensing.-Government or public authorities can use a patent, but the patentee is entitled to compensation therefor. If the patentee has not got his invention to work in the realm within three years of the date of the patent to such an adequate extent as to supply the demand of the public, he can be compelled to grant licenses to trustworthy manufacturers at a reasonable compensation. Lastly, if another patentee makes an industrial improvement on any patented invention which cannot be worked without the use of the prior patent, the owner of the first patent is compelled to grant a license on 
reasonable terms to the persons so improving on his invention, but conditionally on the owners of the improvement granting him in return a license on reasonable terms. If the terms cannot be decided out of court, the Patent Office decides the point, subject to an appeal to a higher court.

Assignments and licenses may be registered, and until registered are not binding upon third parties acting in good faith.

About $I, 800$ patents were applied for annually up to the beginning of the war, and about 60 per cent. were granted. Of the entire set of applications, nearly one-third came from Germany, and one-third from Norway itself, while only about one-twelfth came from Great Britain and Ireland, one-twelfth from Sweden, and one-ninth from the United States.

Designs for special exterior shapes or decoration can be registered for fifteen years, subject to fees at the end of each triennial period. The registered article must be manufactured in the realm, and the design is forfeited if importation be allowed.

Taxes.-Patents, except patents of addition, are subject to the payment of an annual fee.

Design registration lasts for fifteen years, subject to taxes at the end of three, six, nine, and twelve years. Trade marks are also registrable.

\section{OMAN.}

Population, 500,000.

The owner of an Indian patent can get his rights, to a large extent, extended to Oman. Trade marks can be protected at the Custom House.

\section{PALESTINE.}

(Patent Ordinance x920.)

Population, 600,000.

A patent registered in any other country can be extended to Palestine, without prejudice to the rights of persons already working such in the province, on satisfactory evidence that it is protected abroad and appears to be reasonably new in the province.

In Mesopotamia a similar ordinance will be shortly enacted, and inventions can be now to some extent protected by depositing the papers with the Governor, when on the publication of the ordinance they will be taken in order of date.

The French and Italian mandate countries will probably be protected under French and Italian law as colonies. 


\section{PANAMA.}

(Laws 24 of I4 Nov., I908, and No. 47 of 29 Jan., I9II.)

Exclusive of Canal Zone (see U.S.).

Population, 400,000 .

Patents are granted for from five years to twenty at the option of the applicant, but expire with prior foreign patent for the same invention, but short term patents cannot be afterwards extended. The Colombian law is re-enacted otherwise. Patents may sometimes be extended beyond the twenty years if considered by authorities of sufficient importance. Trade marks are registrable.

The Canal Zone is not under this patent law, but under that of the United States.

\section{PARAGUAY.}

(Convention, I6 January, I889.)

Population, 800,000 .

By a convention with Argentina, Uruguay, Bolivia and Peru, a patent granted in any of these countries can be extended to Paraguay within one year of its date. Paraguay has made a similar arrangement with Great Britain. Medicines cannot be patented.

Except this, there is no patent law in Paraguay. The Government, sometimes independently, grant exclusive privileges for useful inventions.

No annual taxes. Trade marks are registrable.

\section{PERAK.}

(Order in Council 267-No. 2 of 1896.$)$

Population, 330,000.

Inventions patented in Great Britain or any British possession can, during the lifetime of such patent, be patented in Perak for the remainder of such lifetime.

Tax at end of seventh year is required to keep the patent in force.

\section{PERSIA.}

Population, 8,000,000.

Has no patent law. 


\section{PERU.}

(Constitution Act 27, Law of 28 Jan., 1869, 3 Jan., 1896, and Decrees of 20 Sept., I9I2, and 28 Nov., I9I4.)

Population, 3,500,000.

Peruvian patents to inventor or introducer, granted for inventions unpublished anywhere, last ten years, often renewable for ten years more. If a patent has been previously granted first in Argentina, Bolivia, Paraguay, or Uruguay, and application be made in Peru within a year of such grant, publication since the aforesaid patent was applied for does not militate against the patent rights. A similar treaty between Peru, Bolivia, Ecuador, Colombia and Venezuela gives similar protection, but for two years in the others of them. Real industrial working in the realm must be proved within two years, and importation from abroad is not allowed even by the inventor, and the latter must renounce all rights as a foreigner to diplomatic assistance in the matter of his rights as a patentee. The right is independent of foreign patents.

Patents of addition or modification are allowed if they do not affect the principle on which the original invention is based.

Importation of the patented article without special permit in each case nullifies the patent rights if such importation is with the patentee's sanction or connivance.

There are no annual taxes.

Trade marks are registrable.

\section{PHIIIPPINE ISLANDS.}

\section{(Patent Law 2793 and 2860 of I9I9.) \\ Population, 7,800,000.}

An invention not yet published in any country can be patented for seventeen years. Any person making an improvement on any patented invention can have a compulsory license for the original invention during the lifetime of the original patent, on payment of half the Government fees on the aforesaid invention, plus a premium to be assessed by the court if not agreed to privately to be paid to the inventor, and a tax paid to Government, but the original inventor has full and free use of the improvement.

Infringement of a patent is both a civil and a criminal offence, punishable by heavy fine or imprisonment not exceeding two years, damages and destruction of the infringing articles. Persons aiding and abetting the infringement are liable to the same penalties. There are annual taxes of 20 pesos if the invention is not worked in the realm. 


\section{POLAND.}

(Decree of 4 February, I9I9.)

Population, between $53,000,000$ and 30,000,000.

Kind and Duration of Patents.-Patents of invention granted for fifteen years from the date of signature of the patent.

Patents of addition, free of annual taxes, granted to the owner of the patent of invention to expire with a patent of invention. These, however, can be converted into principal patents on or before the expiration of the principal patents on which they are based.

Secret Patents.-Inventions relating to national defence. These are granted, but, immediately after the publication, are submitted to the War Ministry, when if the latter does not within the next three months require the invention to be kept secret it shall become an ordinary case and go through the ordinary curriculum. If, however, the Ministry decide that a patent must be kept secret, they have one year in which to purchase it at their own price or at a price to be fixed by the Supreme Council of Ministers. It is then kept permanently secret, otherwise it is published in due course.

Who can Patent.-The inventor or his legal representatives or assigns.

What can be Patented.-Anything that could be patented in Great Britain or the United States, except chemical products, foods, or pharmaceutical objects, but processes for making these can be patented and this protects products made by such process. Mere trifling improvements or alterations of known inventions may be refused. A single patent may comprise several inventions if they be interconnected by one principal novel idea. The inventions must be new, that is, not published anywhere prior to the application for a patent. It is no bar to the grant of a patent that the invention has been secretly worked by the inventor or others prior to the date of application for a patent.

If there be several applicants for a patent the first applicant receives it unless another successfully opposes him, but anyone who can prove that he worked the invention in the realm before the date of application for the patent can continue to work it in his own business and can sell the invention together with his right to work the invention in that special business only.

Procedure.-The application must be in the Polish language, and follows pretty much the same curriculum as in Great Britain. There is an examination to see if the application be in order but not as to whether it be new, and if the examiners are satisfied the specification is published and is open for opposition-but the applicant can by petition keep publication back for six months. Only the injured party can oppose on the ground that it has been " taken from him," but any interested party 
can do so on the ground that it is not new or not subject matter for a patent. If an applicant succeeds in stopping the invention on the ground that it was taken from him, he (the opposer) can obtain the grant of a patent for the same invention to date from the day of application of the fraudulent application. The first applicant is held to be the rightful owner of the invention if new, unless it be proved that he took it wrongfully from the opponent. From the decision of the opposition court there is an appeal to a higher judicial authority. Until the patent be allowed the applicant has the right of introducing amendments on or additions to the description, provided they do not alter the essential idea.

Taxes.-The patent being granted there is a small annual progressive tax on it on pain of its being annulled. The first three years' taxes and the opposition fee can be allowed by the Ministry to needy applicants.

Working. - The invention must be worked in the realm within three years of the date of grant in a manner satisfactory to the Ministry of Industry and Commerce, but this latter can extend the working time to six years.

Annulment.-Any time within five years of grant a petition may be filed on any of the grounds allowed for opposition, after which it can only be annulled on proof that the invention was taken from the petitioner or that it had been previously patented in Poland.

Military Use.-The military can demand the expropriation of a patent or the granting of licenses for state reasons, but in such case the amount of compensation is determined by the Council of Ministers.

Supplementary patents are granted to expire with the original, which, on the expiration of the original patent, can be converted into an original patent.

Infringers can be prosecuted for infringements made after the patent has been advertised as passed for publication, and injunction and damages obtained.

Assignments and Licenses must be registered.

Patents granted by Russia, Austria or Germany before this law came in force, even though published, can be extended to Poland without prejudice to the rights of third parties if applied for before the 7 th November, I9I9, or before such further date, as the Ministry of Industry and Commerce may extend the term of six months to, but patents so extended must be applied for in Poland with all the formalities, stamps, and costs as original patents. "Rights of third parties" is practically the right to use the patent in his own business in the case of persons already using the invention before the date of the application for the patent in Poland.

Registration of trade marks is allowed. 


\section{PORTO RICO.}

Population, I,I20,000.

The U.S. patent can be extended to Porto Rico any time during the life of the patent, provided the invention be not already worked there by third parties.

\section{PORTUGAL, AZORES AND MADEIRA ISLANDS, AND COLONIES.}

(Decrees I5 Dec., I894, I7 Dec., I903, and II Feb., I9II.) Population : Portugal, Azores and Madeira, 6,000,000 ; Colonies, about ro,000,000.

Only the true and first inventor, or inventors, or assignee can now obtain a patent.

For a patent to be valid, the invention at the date of the patent must not have been published in print anywhere or publicly used in the realm before the date of the patent, or (if obtained under the rules of the Union for the Protection of Industrial Property - see page 22) before the date of the original patent abroad.

Medicines and chemical products cannot be patented, but processes for making the same can be.

There are four kinds of patents. Patents of invention granted for fifteen years; patents of addition for improvements on patented inventions, granted to the owners of such patented inventions, and to expire with the original patent; patents for designs, or models, granted for five years and renewable indefinitely; and monopolies for new industries.

Patents are granted first for Portugal, Azores and Madeira; these can be extended to the colonies by a special application and on paying further fees.

Applications for patents are published before grant, and then open for three months for any one to oppose. The birthplace of the inventor must be given.

There is an appeal from the decisions of the Patent Office.

Patents must be worked in the realm within two years of their grant, or if filed under the Convention three years from date of application, and the working not interrupted for a period of two years, or the Government can annul them. In practice this clause appears to be a dead letter.

A patent dates as regards its duration from the date of grant, as regards the rights of the patentee from the date of application, or if obtained under the Convention from the date of the original first application in the countries of the Union for the Protection of Industrial Property.

The Government can at any time appropriate a patent to its 
own use, wholly or partially, paying such compensation as may be agreed upon or decided by arbitration.

Knowingly infringing a patent is a criminal offence.

After a quiet possession of a patent for seven and a half years the validity of that patent cannot be contested.

Monopolies for New Industries are granted at the discretion of the Government to persons proving that they are qualified and have sufficient capital to introduce into the realm and satisfactorily work there an industry hitherto not existing in the realm. They may be granted for any term not exceeding ten years, and if granted for a shorter period can be extended at the option of the Government to ten years. The monopoly is for exclusive manufacture only-any one can import the monopolised article. A foreigner can only get a grant of monopoly by a sort of naturalisation. The application is advertised and can be opposed. The applicant must give good security to Government that he will duly work his monopoly, and the monopoly will be annulled and security can be forfeited if the industry be not at work within the year to a reasonable extent, or its operations be abandoned for eighteen months consecutively during the term granted.

A Portuguese patent can be extended to cover the African dependencies of Portugal and Macao and Timor and Salor within two years of its grant, to expire with the Portuguese patent.

Registration of designs is granted for Portugal, Azores and Madeira only (not the colonies).

n There is an annual tax on patents of invention.

Designs or models can be registered for Portugal only.

(All registrable goods are divided into 56 classes for designs, into 62 for models, and into 80 for trade marks.)

\section{RHODESIA.}

(See Southern Rhodesia.)

\section{ROUMANIA.}

(Law of 26 January, I906.)

Population, about $\mathrm{I} 7,000,000$.

Kind and Duration of Patents.-Patents of invention are granted to the inventors thereof for fifteen years for new inventions. Patents of improvement on original inventions still running are granted to the inventor of the original invention or others for ten years or for the duration of the original invention, whichever is longest. Patents of importation for inventions already protected abroad expire with the original foreign patent or at the end of fifteen years, whichever be the shorter term. These must be applied for within six months of the foreign application. 
Working in the country must be established within four years of the date of the patent and not be intercepted for more than two years on pain of forfeiture of the patent.

What can be Patented.-The law is substantially the same as the British and American, except that no inventions relating to food, medicine, healing, or disinfecting (even veterinary) can be patented. "New" means not published in print or patented more than six months before in any country and not in use in the realm before the date of application for the patent. The Government can expropriate an invention in whole or in part and keep it for Government use, paying such indemnity for the same as a court (on failure to agree privately) may decide to be fair.

There are annual taxes on patents of invention and importation, but none on patents of addition after grant. Trade marks can be registered.

\section{RUSSIA.}

(Law of 20 May / I June, I896.)

Population before the war, I80,000,000.

This law is in abeyance. No patents have been granted during the civil war, and the Patent Office is closed. The following is the law as it stood before the revolution, and as it will probably be in the near future. (Recopied from our last edition:)

Kind and Duration of Patents.-Patents of invention are granted for fifteen years, subject to annual taxes. Patents of addition for improvements on existing patents are granted, to expire with the principal patents.

Patents for improvements on inventions already patented can, however, be obtained as independent patents of invention, and in such cases last for fifteen years.

Patents for inventions first patented abroad expire with the expiration of the period for which the shortest termed foreign patent for the same invention was granted.

Russia, however, will probably join the Union for the Protection of Industrial Property, in which case this last clause will be inoperative in the case of persons claiming under the Union - see page 22. The act of joining the Union makes the treaty retrospective.

Who can Obtain a Patent.-The true and first inventor or his representative, whether Russian or alien, can obtain a patent. During the first year of grant of a patent of invention only the patentee thereof can obtain a patent of addition thereon. After this, others can obtain such patents of addition or improvement, to expire with the original patent; but neither party can use the other's invention without special agreement.

Inventions, however, which are already patented in foreign 
countries can still be legally protected in Russia if the applicant for the Russian patent be the actual inventor of the foreign patent or his assign, and the invention be not yet known in Russia. In such case the Russian patent is limited in its duration by the term for which the corresponding foreign patent of shortest duration was originally granted, copy of which has to be supplied for the purposes of identification.

What can be Validly Patented.-Any new invention capable of industrial exploitation, except:

I. Anything dangerous to the state or public morals, or inventions exclusively for warlike use. See paragraph " Government Use."

2. Anything already patented, or for which a patent has been applied for, in Russia, or which has been worked in the realm.

3. Anything sufficiently described in the literature of any country as to be reproduced therefrom.

4. Anything which is publicly known abroad without being patented, or patented in another name than that of the applicant for the Russian patent, unless such other applicant of the original patent be his assignor, assignee, or representative.

5. Mere unimportant modifications or improvements of wellknown inventions.

6. Chemical products, foods, drinks, medicines, or processes, or apparatus for making medicines.

Novelty.-See last article.

Requirements.-Besides the usual drawings and specification, a model is required when in the opinion of the examiners the case requires such for the full understanding of the invention.

Examination.-Inventions are examined as regards novelty by experts and committees representative of the various departments of state; against the decision of these an appeal can be had to a general meeting of the Technical Committee. Those members, however, whose decision is appealed against have no vote, but are present and can speak. Patent applications were often from three to seven years passing through the office. There is one advantage in delay, however, the inventor is protected from the day of application, but his patent begins to run from the date of grant.

Assignments can be made before issue.

Government Use.-Patents for inventions useful to Government only, such as munitions of war, are not granted, and those useful alike to Government and to private individuals, such as warlike materials that can be used for sporting purposes, are granted with the reservation that the Government shall have the use of them. (Compensation settled by the Council of State.) The Government have power to expropriate a patent altogether and keep the matter secret, the Council of State 
settling the terms of compensation. Severe penalites are ordained against an inventor of such patent if he betrays the secret or takes out a foreign patent.

Provisional Protection.-An application having been made in due form, the name of the applicant, the date of application, and the title of the invention are published, and a certificate of safeguard (provisional protection) is granted. This enables the inventor to publish and work his invention without danger to the subsequent grant of a patent for the same and to notify infringers that they are exposing themselves, in the event of the patent being granted, to judicial prosecution for all infringements made after the date of the certificate of safeguard. Any time before the patent is granted, the grant can be objected to by the examining officials or any other person notifying them that the invention is old or has been wrongfully obtained by the applicant. The objection of the examiners or any notification that the invention is old is submitted to the applicant, who has then three months during which he can furnish a reply, and the general body of the examiners thereupon come to a decision. If, however, the notification be that the invention has been wrongfully or fraudulently obtained, the patent is refused, and the parties are obliged to submit the matter to a court of law, who can make such order in reference to the patent as it may consider right.

The production of a patent granted in Germany for the same invention will often expedite the examination, and Russians frequently apply for patents in Germany before applying in their own country.

Conflicting Applications.-If two applications be filed for the same invention, the first applicant receives the grant, unless the two applications be made the same day or the first be opposed by the second. If the two be of even date, they are invited to come to agreement; and if they do not agree within three months neither application is allowed until the matter has been decided by a court of law.

Working.-A patent must be worked in the realm and the working proved to the Department of Commerce and Manufacture within five years of its grant or the patent will be declared void. This working must be a bonâ fide working of those parts of the invention claimed. Thus if the claim were "in combination with a slotting machine," a tool of a given kind, it would be sufficient to make the tool in Russia. If the invention be for a process of turning articles to a true oval-the lathe that does it can be imported and the process " worked" by using such lathe. It is always safest, however, to make one complete machine in Russia. Babcock and Wilcox had their patent upset, though they had made a patent boiler in Russia, because a small part of it and many complete boilers had been imported from England. 
Assignments of entire interest must be registered, and licenses or partial assignments are not recognised.

Government Guarantee.-During the first two years action can be brought to upset the patent on any statutory ground. After two years, it can only be revoked by a sentence or order of a criminal court.

Patents of Addition are granted to the proprietor of a patent, to expire with the original patent. There are no annual taxes on these. After the first year of a patent any one can apply for a patent of addition thereon, but neither patentee can use the patent of the other without license.

Taxes.-A patent becomes void if annual taxes be not paid as they become due. They can, however, be paid within three months after date on payment of a fine.

New designs or models can be protected for any period up to ten years, not renewable.

Trade marks are registrable.

\section{ST. HELENA.}

(Ordinance No. 3 of 1872 .)

Population, 4,000.

A British patent can be extended to this colony.

There are no annual taxes or compulsory working. The rights expire with the British patent.

\section{ST. LUCIA. \\ (Ordinance No. 14 of 27 October, 1899.) \\ Population, 55,000.}

The English law of I883, with requisite alterations, has been enacted in the colony. There are no compulsory working clauses.

\section{ST. VINCENT. \\ (Ordinance of 30 June, 1898 .) \\ Population, $5 \mathrm{I}, 000$.}

The English law as it existed in I888, with slight modifications to adapt it to the colony, has been enacted in St. Vincent.

Annual taxes have to be paid before end of the fourth and each subsequent year. 


\title{
SALVADOR.
}

(Laws of 24 April, I9oI, I May, I909, and I9 June, I9r3.)

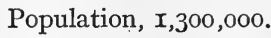

Who can Patent.-Only the true and first inventor, or his attorney for him, can validly obtain a patent.

What can be Patented.-Practically anything patentable in Great Britain or the United States not yet published in any country except in official Patent Office publications, or through being exhibited in international exhibitions. A patent can only be for one article or process, and if two or more have to be combined to produce a new industrial result there must be two or more patents. There is an examination system by experts and oppositions are allowed prior to the grant of the patent.

Kinds and Duration of Patents.-Patents of invention for fifteen years and patents of addition to expire with original patent, and patents of precaution, equivalent to an American caveat, which lasts a year and can be renewed for one more year ; these are kept secret, but can be used as evidence in oppositions.

The patent can be renewed by the Executive at the end of the fifteen years for a further period of five years; then a fresh tax is required. In the case, however, of inventions patented abroad, the patent falls with the first foreign patent. All applications are published for three months, when, if there be no opposition and the papers appear in order, they are granted.

Government can compulsorily purchase a patent, and, if the inventor refuse to work the invention in the realm, can annul the patent.

Otherwise there is no compulsory working clause.

Annual taxes have to be paid on all patents, even patents of addition, on pain of forfeiture of:patent.

\author{
SERVIA. \\ (See Jugo-Slavia.) \\ SEYCHELLES ISLANDS.

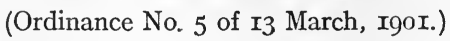 \\ Population, 23,000.
}

This law is very similar to the British, the differences being, first, an assignee of the inventor's right can apply for a patent.

Taxes have to be paid before the end of the fourth and each subsequent year to maintain the patent in force.

\section{SHAN STATES.}

The Indian Patent Acts of 1898 and I9Io have, by notification, been extended to the Shan States. 


\section{SIAM. \\ Population, 6,700,000.}

The English Patent Act extends to Siam in so far that any British subject or subject of any other country which has come into the arrangement in Siam can be prosecuted in a consular court in Siam by the owner of a British patent for infringement of such British patent in Siam, provided that the owner of the said British patent is a British subject or a subject or citizen of another country making the same arrangement in Siam in regard to its subjects or citizens.

A law for the registration of trade marks has been passed.

\section{SIERRA LEONE AND PROTECTORATE.}

(Ordinance No. 3 of 6 March, I9r3.)

Population, white, 500 .

$$
\text { " coloured, 6,700,000. }
$$

The owner of a British patent can obtain protection in the colony, to expire with said British patent. A patent can be declared void on most of the grounds that a British patent can. There are no compulsory licenses. The privilege is very little used. Trade marks can be registered.

\section{SOLOMON ISLANDS PROTECTORATE (BRITISH).}

(Regulation No. I, I9I7.)

British patents can be registered in the islands so as to be operative therein as long as the British patent remains in force.

\section{SOUDAN (ANGLO-EGYPTIAN).}

Population, 2,000,000.

There is no patent or trade mark law for the Soudan. The French law covers the French Soudan.

\section{SOUTH AFRICA (UNION OF). \\ (Act No. 9 of $19 \mathrm{I} 6$. .) \\ Population, white, $1,500,000$.$$
\text { " coloured, 3,500,000. }
$$

Formerly the Cape of Good Hope, Natal, Transvaal, and Orange Free State, each granted patents independently. The owners of these had the option of exchanging them on certain terms under the present law for Union patents or of continuing their provincial patents under the provincial laws but of paying their taxes at the Patent Office of the Union at Pretoria Patent Office. 
The Patent Law of the Union of South Africa is practically identical with the British, except as follows : Patents are granted for fourteen years instead of sixteen. In an opposition, the opponent is allowed to plead want of novelty against the patent, and instead of the heavy annual taxes required by the British law there are small taxes just before the ends of the third, seventh, and tenth years on pain of forfeiture. Compulsory licenses can be applied for at the end of two years instead of four.

South Africa has joined the Union of Industrial Property (Convention), see page 22.

\section{SOUTHERN RHODESIA.}

(Ordinance No. 7 of I904.)

Population, white, 23,000.

$$
\text { , coloured, 800,000. }
$$

In September, I904, an Act, almost a copy of the English law of 1883 , was passed, but the rules $r e$ oppositions are greatly improved, and costs allowed to the winning party.

The prior grant of a foreign patent for the same invention does not affect the Rhodesian one if the latter be applied for within one year of such grant. Publication in the interim is also no bar to validity.

Provisional protection lasts nine months, the patent I4 years.

Annual taxes, to maintain the patent, commence at the end of third year, increasing annually. If taxes be accidentally delayed, they can be paid during the next three months with a fine, depending on the time elapsed since they were due.

No design registration. Trade marks are, however, registrable.

\section{SPAIN AND COLONIES.}

$$
\begin{gathered}
\text { (Law of } 7 \text { June, I902.) } \\
\text { Population, Spain, 20,000,000. } \\
\text {," Colonies, 500,000. }
\end{gathered}
$$

There are three kinds of patents:

I. Patents of Invention for twenty years granted to any person, firm, or corporation who intends to establish, or who has established, a new industry unpublished and unpractised at home or abroad, except in international exhibitions (when exhibited by the patentee) or under the exceptions allowed by the Union for the Protection of Industrial Property; but experimental use by the applicant before patenting is not considered publication or practice of the invention. 
2. Patents of Importation for five years granted to any person, firm, or corporation who establishes an industry new in the realm, though it may have been worked or published abroad.

3. Certificates of Addition, Alteration, or Improvement on original patented inventions which are made by the patentees of such original patented inventions and which lapse with the original patent, and after grant form a part of the original patent.

Patents of invention and their certificates give the sole right of making, using, and importing.

Patents of importation do not give any right to stop importations of the patented article.

Medicines cannot be patented, but modes of producing them can, and their names can be registered.

There is no examination as to novelty, but all applications are granted if in order.

The holder of the patent can at any time after grant during its existence obtain a certificate of addition, alteration, or disclaimer for any improvement, alteration, or deletion he wishes to make in the specification, and the patent from thenceforth is modified by that certificate, but without prejudice to the rights of other parties existing at the time. There are no annual taxes on these certificates, but they fall with the original patent.

A patent can be expropriated by a special Act of Congress, in which case the indemnity for such expropriation is also decreed, and who is to pay it.

Working.-A patent must be worked in Spanish territory, within three years of the date of the patent " in reasonable proportion to its employment or consumption "; and that working proved before an official (who grants a certificate and is much more strict than formerly). If there be no market, the existence at the disposal of the public of machinery or materials sufficient for the manufacture will be considered a working. Any rival manufacturer or any person who has been refused a license can challenge in a court of arbitration at his own expense the sufficiency of such proved working. It is sufficient to upset the patent to show that working has been suspended for a year and a day without very strong reason.

Licenses and Assignments must be registered at the Conservatory of Arts (Madrid) before they become valid against third parties. This register is always open to public inspection.

Nullification.-As in most other countries, if it be found that the specification does not fully and correctly describe the invention and its objects, so that any one could work it who is conversant with the branch of art to which it is nearest related, or if there be clear evidence of deceit or of reservation of valuable information on the part of the patentee in drawing up his specification, the patent will be declared void.

Infringers of Patents are liable to a fine of from $£^{8}$ to $£^{80}$ for 
the first offence ; if, after being fined, the infringer again infringes within a period of five years, he is liable to a fine of from $f 80$ to $£ 800$. Persons knowingly assisting in such infringement lay themselves open to a fine of from $£^{2}$ to $£^{8}$ for the first offence, and of from $£ 8$ to $£ 80$ for the second. All counterfeit products seized become the property of the patentee, and all damages must be made good ; and if the fines and damages be not promptly paid, imprisonment for an equivalent period is the only alternative. In infringement trials, the infringer can plead invalidity of the patent, and get his action suspended till the validity of the patent has been tested by the public prosecutor before a jury of experts.

New ornamental designs and patterns are registrable for 5, Io, I5, or 20 years.

What Inventions Pay.-The spirit of enterprise is rapidly rising again in Spain; and at the present time there is a great demand for manufactures requiring small capital to work them. Patents for small domestic articles, stationery, simple articles of husbandry, or connected with the wine trade, mining, and guns and pistols, are especially sought after. About 2,500 patents are issued annually.

Taxes.-Patents are subject to an annual progressive tax on pain of forfeiture. Accidental non-payment can be rectified by fine within three months. All the taxes can be paid at once if desirable, in which case a discount of 5 per cent. on five-year patents and 20 per cent. on twenty-year patents is allowed.

Trade marks can be registered.

\section{STRAITS SETTLEMENTS.}

(Ordinance No. I2 of I87r.)

Population, 700,000 .

These include Singapore, Penang, Province Wellesley, and Malacca. The patent law is very similar to the British, except that there are no compulsory licenses or annual taxes. Any inventor possessed of a British patent can have the same registered in the colony at any time during its existence so as to be operative over the Settlements. The first importer of an invention can obtain a valid patent therefor. Duration of patent, I4 years.

\section{SWEDEN.}

(Laws of I6 May, I884, and 9 May, I902.)

Population, 5,500,000.

Kinds and Duration of Patents.-Patents of invention are granted for fifteen years, subject to an annual tax. Patents of addition, for improvements on existing patented inventions, are granted to the original inventor of said existing patent, free of 
annual tax, to expire with the original patent. And at the option of the King, provisional protections for one year to subjects of countries granting reciprocity in this respect.

Who can Patent.-Patents are granted only to the true and first inventor, or his legally qualified representative or assignee.

What is Patentable.-All new industrial inventions and new modes of manufacture, except foods and medicines, are patentable ; the modes of compounding foods and medicines are, however, patentable if new.

If an application contain more than one invention, the rule set forth under Denmark is followed (see middle of page 79).

Novelty.-An invention is new if it has not been already described in any country in an ordinary accessible printed publication, or so openly practised that any one skilled in the art to which it relates could manufacture it from such information. The publication of the invention, however, by exhibition at an international exhibition, is no objection to the grant of a patent, provided that the applicant applies for a patent within three months after such publication or opening of such exhibition.

Publication of the invention by a foreign patent authority is, however, sufficient to invalidate a subsequent application in Sweden, unless such application be made under the provisions of the International Convention, and such publication be after the date of priority secured under the Convention.

In the case of an application for a patent for an invention first patented abroad, in a country under the Convention or having a corresponding regulation, a Swedish patent is granted without being prejudiced by interim publication, to date the same date as the said foreign patent, provided the application be made within twelve months of the date of application for the foreign patent.

Requirements as regards a full and complete specification are as strict as in England or America, and a model or samples may be called for. An applicant outside the realm must have a resident representative (his patent agent's correspondent is sufficient), who, in all matters of the patent, shall be considered the representative of the patentee. He can be changed by the patentee for some one else, but if he dies, or leaves the country, another must be appointed. There is an examination as to sufficiency of description of the invention, and also as to novelty. If two inventors apply for the same invention, the first applicant has the preference.

Applications on being allowed are advertised, and for two months are open to opposition.

Assignments to be valid have to be registered, and until such registration the registered owner for the time being is the legal owner. Any second assignment from him, therefore, registered before a previous assignment takes precedence of the latter. 
Working.-All patents except as hereinafter stated must be worked in a substantial manner in the kingdom, commercially, within three years of their date, and the working once begun must not be intermitted for an entire year, otherwise, on the application to the courts by a third party, the Government can grant a license on such terms as regards compensation to the patentee as the court may consider just. The patent authorities, under exceptional circumstances, can extend the time.

Any foreigner having a bonâ fide industrial or commercial establishment in the realm, and having patents for the same invention in Sweden and in his own country, will be held to have "worked " the invention in the realm if he works it in his own 'country.

Rights conferred.-A patent in Sweden confers substantially similar rights to what a patent in England does. A patent is not valid against any one who, before the date of the patent, either used the invention in the realm, or made extensive preparations-such as by putting down plant-for such use. The Government can confiscate a patent for the public good, or Government use, but must indemnify the owner. In such case, if the owner and the Government cannot agree as to the amount of the indemnity, a special Commission assesses the amount.

The Penalty for Infringing a Valid Patent is a fine of not less than 20 crowns ( $£$ I 2s. $2 \frac{1}{2} d$.) or more than 2,000 crowns ( $f$ III), or imprisonment; and if after the commencement of the action the infringement has been continued, each time a summons has been served-provided the infringement has been continued between the dates of serving-entails a separate fine.

Nullification.-Any one can contest the validity of a patent at law; and if the verdict be against the patentee, the fact is registered in the Patent Office.

If a patent be rejected, part of the fee is returned.

About 3,500 patents are applied for annually, and about 2,000 issued.

Sweden is a large iron, steel, wood-pulp and timber-producing country and has abundance of water power.

New models or designs relating to metal industry only, can be protected for five years.

Taxes.-Patents of invention are subject to an annual tax before the end of each year. The payment of this tax can at any time be discontinued, and the patent allowed to go void. If accidentally omitted, it can still be paid, and the patent hold good, provided the amount of the tax, together with one-fifth of the amount by way of fine, be paid within the next ensuing three months after the date when the tax became due.

Trade marks are registrable. 


\section{SWITZERLAND.}

\section{(Laws of 21 June, I907, and 30 March, I9II.) \\ Population, 3,900,000.}

Kind and Duration of Patents.-Patents for new inventions other than medicinal are granted for fifteen years; medicinal ones for ten-in each case from the date of application. A patent for an improvement on a prior patent owned by the applicant is granted to expire with the original patent. If an original patent becomes void, its patents of addition can during the next three months be converted into full patents.

What can be Patented.-Any new invention susceptible of being patented in Great Britain or the United States can be protected in Switzerland, except those for chemical substances and processes for the manufacture of chemical substances intended principally for the nourishment of man or beast, medicines, food, or beverages which are manufactured by other than purely chemical processes, and processes not purely mechanical for improving textile fibres or fabrics. Two inventions cannot be combined in one application, and in the case of chemical processes each patent must be for the manufacture of only one product, and the constituents must be clearly and accurately set forth, and full sets of samples of the constituents and of the finished product supplied. If variations of the process consisting in the employment of equivalent chemicals to those set forth in the original patent, and for the production of products analogous in point of view of their application, have to be covered, such can be taken out as patents of addition on the original patent. Thus if potash be used in the original patent, patents of addition can be obtained for soda and ammonia replacing it; but the original patent cannot be taken out in which the word "alkali" is used instead of soda, potash, or ammonia. Except in chemical patents, a process and a product can be covered in one patent.

Novelty.-An invention is considered new if it has not been publicly known in Switzerland or appeared in print in that realm before the date of application for the patent, sufficiently to enable those skilled in the art to which it relates to make and use the same. Any person who has worked an invention in Switzerland, or made bon $\hat{a}$ fide arrangements for working it before the date of the application for a patent, can continue to work it in his own works without paying royalty. He can sell or assign this right to another only together with the business.

Rights conferred.-These are similar to those conferred by patents in Great Britain or United States.

Working.-Patents must be worked in a bonâ fide manner in Switzerland within three years of application on pain of for- 
feiture, or any person interested can bring an action for nullification, and the patent will then be nullified unless in the opinion of a court the inventor justifies his inaction by convincing the court that he has done the best he could or that the invention was actually at work in the realm at the date on which the action was commenced. By an agreement between Germany and Switzerland working in either country is sufficient to satisfy the working clauses in the other, if the invention be patented in both countries and if the patentee be a citizen of or be domiciled in either country.

A person proving in court that an invention has been surreptitiously or fraudulently obtained from him, and patented, can have the patent transferred to him.

Compulsory Licenses.-A license can be compulsorily obtained for any patent by a person proving that he has a prior patent which cannot be worked to best advantage without such license, and if the two parties cannot agree upon the terms of the license, the court will decide what royalty shall be paid. The state can expropriate a patent, paying a fair price therefor.

Patents are published as soon as granted, but an inventor can on petition have his specifications and drawings kept secret for one year from application. About 5,000 patents are granted yearly.

Switzerland has joined the Union for the Protection of Industrial Property, and the office of the Union is at Berne.

Infringers are liable to be punished with a fine of at least $£ 200$ or imprisonment for one year. In the case of a second offence the penalty is doubled. They are also similarly liable for damages to the patentee, and the forfeiture of the counterfeit articles, and plant used in their manufacture, and the sentence can be ordered by the court to be published in the newspapers at the expense of the guilty party.

Any person implying that an invention is patented when it is not, is liable to a fine of at least $£ 40$, and in the case of a second offence the fine is doubled.

An inventor resident abroad must appoint an agent in Switzerland to represent him. This is usually the correspondent of his local patent agent. In any actions for nullification of a patent, it is sufficient to notify this agent.

There is no examination system as to novelty.

Taxes have to be paid each year on pain of forfeiture of the patent-on principal patents only, patents of addition not being taxed in this way save except when converted into full patents.

Three months' grace is allowed for paying taxes without fine.

New designs and models, or sets of models or designs, registered for lone party at one time, can be protected for five years, renewable to fifteen. Trade marks are also registrable. 


\section{TOBAGO.}

(See Trinidad.)

\section{TRAVANCORE.}

(Patents and Designs Regulation, I9I5.)

A law, closely resembling the British, grants patents for fourteen years, subject to annual taxes after three years and eleven months from application.

\section{TRINIDAD AND TOBAGO.}

(Ordinance No. 76 also No. 13 of I905.)

Population, 330,000.

Fourteen-year patents can be obtained by the inventor or importer, or his assigns, for new inventions.

The colony has joined the Union for the Protection of Industrial Property.

There are no annual taxes, but in other respects the law of patents and trade marks, except as regards costs, is substantially the same as that of Great Britain.

Designs and trade marks are registrable.

\section{TUNIS.}

(Law of 26 December, I888.)

Population, 2,000,000.

The law is very similar to the French, except that a patent can be opposed prior to grant.

There are annual taxes.

A design model, or series of designs or models, packed in a box of not exceeding 40 centimetres in either dimension, or weighing over Io kilograms, can be secured for five, ten, or fifteen years.

Trade marks are registrable.

\section{TURKEY.}

\section{(Law of 2 March, 1880.)}

Population before the war, Europe, 2,700,000.

" $\quad$ Asia, 15,200,000.

Any new industrial product, new means, or new application of known means, for obtaining a new industrial product or result, can be patented, with the exception of medicines and devices for banking or finance. Patents are granted for fifteen years.

Patents are granted without examination, and at the risk 
of the applicant, as in France. In the case of warlike inventions, the Government reserve the right of taking them, and rewarding the inventor, and if they do not take them up they almost invariably refuse them as mischievous to the state. Gold, silver, and copper medals are granted to the inventors of valuable inventions, and the designs of these medals must be reproduced as trade marks by inventors.

Patents of addition, alteration, or improvement can be obtained during the entire duration of patent, free of annual tax, to expire with and form part of the original patent. Patents of addition granted to one owner or licensee of a patent belong equally to all other owners or licensees, in the same proportion and extent as the original patent.

Patents must be worked in the realm within two years of grant on pain of forfeiture on the part of any interested party, and such working must not be intermitted for two consecutive years.

Importation of the patented article by the patentee or his representatives is a ground for revocation of the patent.

The law as regards novelty, introducing specimens into the country, and annulling patents, is the same as the French, except that Turkey has not joined the Union for the Protection of Industrial Property and its rules do not apply. The law against infringements, especially in the case of second offences, is very severe.

An annual tax has to be paid each year.

Trade marks are registrable.

For the newly-occupied Turkish territories (Mesopotamia, etc.), see article "Palestine."

\section{UGANDA PROTECTORATE.}

(Ordinance No. I2 of I July, I9I2.)

Population, 2,900,000.

Inventions patented in Great Britain can be patented in Uganda by the legal owner of the English patent or his assignee. Such patent carries the same powers and privileges in Uganda that an English patent does in England. The law is strictly enforced $r e$ unlawfully marking things as patents; fine, 75 rupees. The patent based on the British expires with it.

\section{UNION OF SOUTH AFRICA.}

(See South Africa.)

\section{UNION FOR THE PROTECTION OF INDUSTRIAL PROPERTY.}

See page 22, International Protection. 


\section{UNITED STATES.}

(Revised Statutes 1897 and Act I4 of I8 Sept., I9I3, and others.)

Population, Iro,000,000.

Kinds and Duration of Patents.-There are two kinds of patents-patents of invention and patents of design.

The duration of a patent of invention is seventeen years, which can be extended only by a special Act of the United States Congress, which is hardly ever passed.

Patents of design are granted for new, original, and ornamental designs for articles of manufacture, and at the option of the applicant for three and a half, seven, or fourteen years. Short term patents cannot, however, be extended after the allowance of the application.

Who can Patent. - Any person, citizen, or alien, even a minor or married woman, being the original inventor, or his executor, or administrator appointed guardian of insane inventor, or foreign administrator, or executor furnishing certified copy of letters of appointment in his own country certified by a United States Consul, can patent. There is one exception to this, however,no employee of the Patent Office can validly obtain any interest in a patent except by inheritance. A patent can be assigned before issue and the assignment recorded, in which case it is issued to the assignee provided the assignment contain a request to that effect and be filed sufficiently in advance of issue.

What is Patentable.- "Any new and useful art, machine, manufacture, or composition of matter, or any new or useful improvement on any art, machine, manufacture, or composition of matter," can form the subject of a valid patent. The invention, to fulfil the definition " useful," must be capable of some use, but the amount of utility is legally unimportant.

A patent can only cover a single invention, but that invention may consist of several parts or combinations, all tending to a common manufacture, and working one with another to the same end, when the principle involved in the combination is newand combinations of known elements can be validly patented if a new or greatly improved result is obtained; improvements, however, of two known and old parts of one machine cannot, as a rule, be patented in one patent, such, for instance, as an improved fly-wheel and an improved piston used in the same engine. Similarly a process and a machine for working that process, or a machine and its product, require separate patents ; but a process of manufacturing a product and that product can be covered in one application. I

Rights conferred by Patent.-A patent gives the sole right of excluding others from making, using, selling, or importing the patented invention from the date of issue of the patent. 
When a patent is granted, the right in the subject-matter relates back to the time of the invention, so that the party who has practised the invention, between the time of the discovery and the issuing of the patent, must cease to do so, or can be sued for infringement. The same is true of acts done in violation of a patent which is surrendered and re-issued on account of defects in the specification if such violation be done subsequent to the granting of the disclaimer (see page I52). Any person, however, who has purchased from the inventor, or with his knowledge and consent constructed any newly invented machine, manufacture, or composition of matter, prior to the application by the inventor or discoverer for a patent, has a right to use, and vend to others to be used, the specific machine, manufacture, or composition of matter so made or purchased, without liability to the owner of the patent.

Novelty.-Each application in America is rigidly examined as regards novelty.

The invention must not have been in public use or on sale in the United States more than two years previous to the application, must not have been abandoned to the public, and must not have been fully described in any printed publication, more than two years prior to the date of the American application, or have been published or patented by another party in any country prior to its invention by the applicant, and no foreign patent for the same invention must have expired prior to the application for the United States patent. Nor will a United States patent be granted after the grant of a foreign patent for the same invention to the applicant or other party if the application for the foreign patent took place more than twelve months before the application in America. By "full description" is meant such description as would enable a competent workman to work the invention successfully, without experiment or inventive talent. The mere use, however, of the invention abroad will not prevent any other person who may invent independently from validly patenting it in America, provided it has not previously been fully patented by any other person in any other country, or appeared anywhere in print prior to his invention of the same in the United States or of his introduction of it therein.

The American Patent Office is the most perfect institution of the kind in the world, but unfortunately has twice suffered seriously by fire, once in 1836 , when the entire records, models, etc., were burnt; and again in 1877 , when a large wing of the beautiful museum of models was destroyed.

Procedure in obtaining Patents.-Every applicant must produce a specification and drawing where the case admits of one, made according to the rules of the Patent Office, which are very exacting, and in rare cases-where the examiner considers 
that it is essential to the proper understanding of the inventiona model. This model must not be over one foot in length, width, or height, and if made of pine or other soft wood, must be painted, stained, or varnished. Glue must not be used, and it must be capable of resisting without damage the action of ordinary heat and of moisture. The name of the inventor, and the exact title of the invention, must be affixed to it in a permanent manner. In patents for compositions, specimens of the article and of each of its ingredients (when not dangerous or liable to decomposition) may be requisitioned by the examiner to be provided in neatly labelled bottles. Neither a machine and its products nor a process and mechanism for carrying out that process can be combined in one patent, nor can two alternative methods of carrying out the invention be specifically claimed-both can be shown, and one method, and the matter common to them both, can alone be claimed. A claim that would be admirable in England as claiming the invention concisely and clearly will often not be allowed in America as setting forth a principle, or a function, while the usual run of claims of American patents are unsuitable for England, from their omitting to claim anything more than the specific combination. While English courts construe the claim rigidly, but admit the right of the inventor to claim all applications of a new principle, if he describe one such application and set forth the principle in his claim, the United States courts hold a patent invalid if it claim a principle, or even a special adaptation of a principle, " and its mechanical equivalents." At the same time, while vigorous in disallowing all claims for principles, the United States courts are extremely liberal in construing claims, especially in the case of "pioneer" patents or patents of considerable originality, adjudging everything to be an infringement if the same result be obtained by equivalent means operated on the same principle as the adaptation claimed.

In the words of Justice Nelson, in Blanchford $v$. Beer, " No man can appropriate the benefit of new ideas which another has originated and put into practical use, because he may have been enabled by superior mechanical skill to embody them in a form differing in appearance or differing in reality. For although he may not have preserved the exterior appearance of the previous machine, he may have appropriated the ideas which give to it all its value."

If, however, another inventor discovers a new mode of accomplishing the same object, embracing fresh principles, and not mere mechanical equivalents of the original invention, the Government will grant a patent to the second inventor, and the new mode will not be held an infringement of the older patent, unless the latter claim the object itself.

The applicant must make oath or affirmation that he verily believes himself to be the true and first inventor, and that he 
does not know and does not believe that the same was ever before known or used prior to his invention thereof (and if it be already patented abroad, he must state, in his oath, where and when it has been patented), and that it has not been in use or on sale in the United States, to the best of his knowledge and belief, for a period of more than two years prior to the date of application in that country, and that it is not described in any printed publication before his invention thereof, and has not been patented in any country on an application filed more than twelve months prior to the date of his American application.

The specification and drawings having been filed, with the necessary fees, the invention is examined by the examiner of the class of inventions to which it relates (each examiner having all applications on certain specified subjects or classes apportioned to him). If the invention be, in the opinion of the examiner, new, useful, and sufficiently described, it is granted; if otherwise, it is referred back to the applicant or his agent, with objections and references to prior inventions covering part or all the ground of the alleged invention. The applicant is then permitted during the space of one year to alter his claims to obviate the objections, when it is again examined. If new grounds of objection be stated, another year is allowed to overcome them or make amendments. Should the examiner eventually reject it, appeal can be made at moderate rate to a board of five examiners-in-chief, of whom three form a quorum, and again, if desirable, to the Commissioner, and even from him to the Court of Appeals of the district of Columbia. The examiners, as a rule, however, are very just and liberal in their decisions, and very few appeals are required when we consider the vast number of applications (upwards of 60,000 to 70,000 a year).

If an application be granted, a final fee of $\$ 20\left(f_{4} 2 s .6 d\right.$.) has to be paid strictly within six months, or the issue of the patent is withheld. Any person who has an interest in the invention may renew the application on the original papers, provided the second application be made within two years after the allowance of the original application. Abandonment in such situation will be considered as a question of fact.

The question of priority of invention does not consist in who first conceived the idea, but who both first conceived and first worked it out into practical success. The mere first conception, if not diligently worked out, will not be held of value against a subsequent inventor who worked out the invention first into a practically useful result.

Whenever an application is made for a patent which, in the opinion of the Commissioner, would interfere with any pending application, or with any unexpired patent, he is required to give notice thereof to the applicants, or applicant and patentee, as the case may be, and an interference is then declared upon 
claims common to the two applications. Proofs are taken and briefed, and the matter is argued in the first instance before the Examiner of Interferences, who awards priority to one or the other, or partly to each, as in his judgment seems appropriate. From his finding appeals lie successively to the Examiner-inChief, to the Commissioner, and to the Court of Appeals of the District of Columbia. A patent will issue in accordance with the finding of the highest one of these several tribunals to which the case is taken by appeal. Though a patent may be issued to an applicant who has successfully contested an interference, with a patentee, the Commissioner has no power to annul the earlier granted patent. Either patentee may institute proceedings in equity to have conflicting claims of the other party's patent declared void, and this may be done as to the whole of the United States and its territories, or for a particular section only thereof, according to the interests of the parties involved. Damages can be recovered only for the period subsequent to adjudication of the cause. The same questions may be tried out in the event of suit being brought for infringement of either patent.

Either patentee may bring a suit in equity, in the nearest United States circuit court, against the owners of the other interfering with him to stop such interference. Separate state courts have no jurisdiction. The court can adjudge and declare either patent void, in whole or in part, and decree costs, and also damages to the successful litigant, not exceeding in amount three times the actual damage proved to have been sustained.

Re-issues.-If, soon after a patent be obtained, the owner finds that through accident, inadvertence, or mistake, the specification was unintentionally drawn up so as not to sufficiently or correctly explain the invention, or to claim all of the invention set forth in the specification, drawings, or model, he can surrender the patent to the Government, and demand one or more new ones for the unexpired portion of the term of the original patent, setting forth and claiming the invention fully. The cost of this re-issue is usually a little more than that of the original patent. The specification and claims are examined and dealt with by the examiners, the same as if forming part of an original application. The patent when thus re-issued is as good against infringements taking place after the date of re-issue as an original patent could be, but it cannot be used against parties who have acquired intervening rights between the date of the original patent and the date of the application for re-issue. What are, and what are not, intervening rights is a matter for the courts to decide. No new matter can be inserted in a reissue patent, but only such as can be reasonably shown by the model, drawings, or specification to have been intended to form part of the original specification. This re-issue system was till 
lately allowed to be applied to all patents still in force, but was found to open a door for fraud, and, latterly, the United States authorities have refused to allow re-issues unless made within a reasonable time after the issue of the original patent, and unless it be evident from the original patent drawings and specification that the inventor intended to cover the matter added in the re-issue, its mere presence in the drawings and models not being held sufficient. The re-issue must satisfy the authorities that it was a part of his original invention.

Disclaimers. - If the owner of a patent discover that, through ignorance or accident, his patent has been made to cover matter of which he or the original patentee of his patent was not the true and first inventor, his patent will still be held valid for those portions of his invention that are rightfully his, provided, as soon as possible after he becomes convinced of having claimed more than is rightly his, he files a disclaimer at the Patent Office disclaiming the portion not legally his own. This disclaimer, if in due form, and accompanied by the required fee, is always allowed, but it must in no way enlarge the scope of the claims. The patent is now unimpeachable, in so far as having previously contained what was old is concerned. The filing of a disclaimer has no effect on an action pending at the time for infringement of a sound part of the patent, unless the infringer prove that the party disclaiming unreasonably neglected or delayed to file the disclaimer, in which case the infringer will gain his case with costs.

Infringements.-In cases of infringements the defendant can successfully plead any of the following pleas:-

$r$. That the patentee kept back a part from, or added something to, his specification, with intent to deceive or withhold from the public a valuable part of his invention.

2. That the patentee surreptitiously or unjustly obtained the patent for that which was in fact invented by another, who was using reasonable diligence in adapting or perfecting the same.

3. That the alleged invention had been patented or was described in print before the patentee's supposed invention or discovery thereof.

4. That the patentee was not the original or first inventor of any material part thereof.

5. That the said invention had been in public use or on sale in the United States for more than two years before the patentee's application for the patent, or it had been abandoned to the public.

6. That it was patented abroad prior to the United States patent, and on an application made more than twelve months prior to the United States application.

If none of these pleas be sustained, and the infringement be proved, the damages are assessed and levied on the infringer. 
The court has the power in flagrant cases of increasing the damages up to threefold, but this option is very rarely put in force.

Damages cannot be recovered for infringements made more than six years prior to the filing of the bill of complaint or the issue of the writ.

If the patentee sue on several claims and he fail on one or more of these, but he succeeds with others, the case is decided in his favour as regards an injunction, but he usually has to pay a part or all of the costs in such case.

To successfully plead abandonment of the invention to the public, it is necessary to show that the invention was publicly used, worked, or sold extensively in the United States by parties independent of the inventor, with the knowledge and tacit or expressed concurrence of the inventor before his application for a patent, or that by some well-defined action he offered the public the free use of it. Allowing others to use the invention as an express favour, or on royalty, for a period of less than two years immediately prior to the application for the patent, is not an abandonment to the public. But the open concurrence in independent parties using, working or selling the invention in the United States prior to the application is an abandonment to the public.

Infringement of a patent consists in making, using, selling, or importing the patented article or process without license from the patentee. A mere workman employed by another to use or operate a patented machine or device is not an infringer, but his employer is. Sale by a sheriff is not an infringement. The sale of articles produced by a patented machine or process, if not themselves patented, is not an infringement.

The description of a part of an invention in a patent specification, but specially reserving it as covered by another pending application, and claiming other parts, does not amount to an abandonment of the unclaimed part to the public.

Assignments and Licenses.-A patent can be sold or assigned, in whole or in part, by an instrument in writing, but that conveyance is not binding against any subsequent purchaser or mortgagee purchasing or mortgaging in good faith, unless within three months of the date of the document it be recorded in the Patent Office. Licenses need not be recorded. Joint owners of a patent without special agreement are not partners, but each can work the invention independently of the other, and grant licenses, but not exclusive licenses, to third parties. He is, however, not liable to them for a share in the profits obtained by his own working of the patent, so long as he works the actual machine or thing patented. It is, therefore, very desirable in the case of joint patentees to have a properly drawn agreement from the outset.

The holding of a simple license, without covenants or recitals 
acknowledging the validity of the patent, does not prevent, under some circumstances, a licensee from afterwards contesting the validity of a patent, and using its invalidity as a plea for not paying royalty or for infringing. It is permissible for him to make use of " the prior art" as determining the construction to be placed on the claims of the patent, for the purpose of getting the court to decide the question of infringement. But a licensee cannot hold his license and at the same time contest the validity of the patent.

A patent can be granted and issued, or " re-issued," to the assignee of the inventor, but the assignment must first be registered at the Patent Office, and in all cases the original inventor must take the oath, and sign the specification. The executor or legal representatives of a dead inventor can take the oath, and obtain the patent in trust for his heirs.

Marking Goods.-All patented articles should be inscribed with the word "Patented," and the date of the patent; but if this be impracticable, owing to the nature of the article, the inscription can be placed on the case or wrapper instead. Any patentee failing so to mark his goods will be debarred from obtaining damages in suit for infringement, unless he proves that the infringer continued to infringe after being duly notified of the patent.

Any person wrongfully marking anything as "patent," or " patented," or other similar expression, or with the name or trade mark of a patentee with the purpose of deceiving the public, is liable to a penalty of $\$$ IOO $(£ 20)$ for each offence, one-half of which goes to the informer prosecuting.

Design Patents.-Patents are also granted for new, original, ornamental designs of manufactured articles. These do not require a model, if the drawings and specification fully describe them. They are granted for three and a-half, seven, or fourteen years, at the option of the applicant, the price of course varying. Where the applicant, in the first instance, requests a patent for one of the shorter terms, he may, at any time before the allowance of the application upon payment of the additional fee, amend his application to request a longer term. Except in these respects, and the rule that a design patent must be applied for in the United States within four months of its being patented in any other country, the same rules apply to patents of designs as to those of invention.

United States patents cover the Canal Zone, Panama, and can be extended to the Philippines and Porto Rico, on application with fees.

There are about 65,000 applicants for United States patents yearly, of which about three-fourths are granted, upwards of a million having been issued by June I9I4, and about 350,000 are still nominally in force. Copies of specifica- 
tions can be had at low rates, as in the English Patent Office.

There are no annual taxes.

Trade marks are registrable.

\section{URUGUAY.}

\section{(Law of 12 November, 1885.)}

Population, $\mathrm{r}, 400,000$.

Patents of invention except for medicines and chemicals are granted to the original inventors of inventions which have not yet been published in print at home or abroad, and that are not in use in the realm and have not been worked more than one year previously abroad. Financial devices are unpatentable.

Patents of importation are granted for inventions already patented abroad - not more than one year prior to the application in Uruguay - and prior publication of the foreign patent does not invalidate them. Patents of addition are granted to the original patentee for improvements on his original patent. They are also granted at a higher rate to other parties, but these must pay to the original patentee such royalty as the Government shall decide to be fair.

Patents are granted at the option of the applicant for three, six, or nine years, not renewable. Models or specimens of good workmanship are required where the case admits of them.

There is an annual tax, and if this be omitted to be paid any year for ten days after it becomes due, the Government considers the patent void. A period during which effective working must be commenced in the realm on pain of forfeiture is stated in the grant of each patent, being generally limited to one year from grant. The Government has power to prolong the term (if petitioned) beyond the stated period, but all terms must be strictly observed, and a foreigner should not count on favour.

Infringement is both a criminal and civil offence, entailing fine, imprisonment, forfeiture of the counterfeited articles, and costs and damages.

A patent granted in the Argentina, Paraguay, Bolivia, or Peru carries with it provisional protection for one year in each of the others.

Trade marks are registrable.

\section{VENEZUELA.}

(Law of 25 May, I882, and Decree of 28 February, I905.)

Population, 2,600,000.

Patents are granted to the true and first inventor only, for five, ten, or fifteen years, at his option, for new inventions other 
than medicines-that is, inventions not yet known to others in the realm, and not published anywhere, and that have not been worked anywhere more than two years. If an invention be not worked in the realm within the first half of the term of its grant, and it be shown to the satisfaction of the court that the inventor is not able or willing by himself or by agents or licensees to satisfy the legitimate demands of the country, the patent can be declared void.

Any one obtaining a patent of invention for an invention in Venezuela, Bolivia, Colombia, Ecuador, or Peru, is provisionally protected for such invention for two years in the others of them.

Importing a machine from abroad, if it cannot be conveniently made in the country, is held to be working so long as that machine is worked in the realm, provided that the patentee or his representatives are prepared to supply others.

Patents are granted, as in France, without guarantee of the Government, and without an examination as to novelty or utility.

Patents of importation, and to expire with said foreign patent, are granted to the patentee and inventor of any foreign patent for the same invention, at any time during the continuance of such foreign patent, provided no prior applicant has claimed the invention.

There are annual taxes after the first half of the duration of the patent.

Trade marks are registrable.

\section{WEST INDIES.}

Hispaniola, divided into the two republics of Hayti (population, $I, 250,000$ ) and St. Domingo (population, 800,000 ), has no patent law, but special privileges can sometimes be obtained from the two legislatures at moderate rates.

Cuba (population, 2,I00,000), Jamaica (population, 850,000), and Trinidad and Tobago (population, 350,000), the Leeward Islands (population I40,000), British Honduras (population, 50,000 ), the Bahamas (population, 60,000 ), St. Lucia (population, $55,000)$, St. Vincent (population, 5I,000), Bermudas (population, I8,000), and Grenada (population, 73,000), all of which have been noticed in previous pages, require each a separate patent.

\section{ZANZIBAR PROTECTORATE.}

(Orders Nos. Io of I9II and I6, I9I7.)

Population, about 200,000.

Any valid patent granted in Great Britain or India can be practically extended by its author or owner to Zanzibar for the 
duration of such patent, provided at the date of application it be not publicly known in Zanzibar. There are no compulsory working rules. There is a tax before the end of the fourth and eighth years instead of annual taxes; in other respects the law is very similar to the British. Actions for infringement or revocation take place before his Britannic Majesty's Court in Zanzibar. 
PRINTED BY

HAZELX, WATSON AND VINEY, LD., LONDON AND AYLESHURY. 




A 000949865 
$(1)=0$

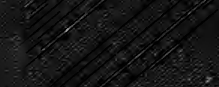

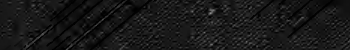

$8 \%$

(1)

(3)

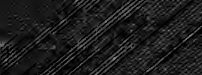

10

8

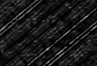

\section{(1)}

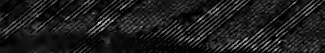

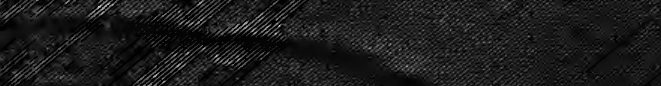

1)

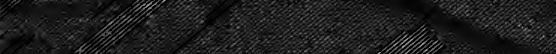

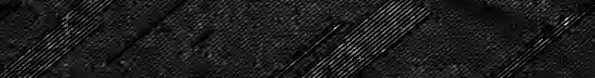

